\title{
THE REGULATORY AND SUPERVISORY FRAMEWORK FOR FIXED INCOME MARKETS IN EUROPE
}

\author{
HUBERT GRIGNON DUMOULIN AND MOGENS KRUSE*
}

(The study describes the regulatory and supervisory framework as of July 2003.)

\begin{abstract}
This paper looks at the development and regulation of fixed income securities markets in Europe. Fixed income securities markets in Europe have historically been characterized by a number of national markets that were interconnected via the foreign exchange markets. They are presently undergoing major changes in size, infrastructure, and regulation. The paper describes the current state of the on-going European regulatory and supervisory reform and the main drivers behind it. The authors conclude that European fixed income securities market regulation and infrastructure are not (yet) homogeneous. In some countries fixed income market regulation has been developed after intense political reflections on ways and means of promoting safe and efficient capital markets. In other countries, fixed income market regulation is a product of learning-by-doing (e.g, ad hoc reflections based on negative market experiences, financial scandals, etc.). To illustrate the heterogeneity in the European fixed income markets, the reports includes two examples: France as an example of a country from the euro area, and Denmark as an example of a country outside the euro area.
\end{abstract}

JEL Classification Code: G18, K22

Keywords: Debt Markets, Fixed Income Markets, Regulation, Supervision

World Bank Policy Research Working Paper 3308, May 2004

The Policy Research Working Paper Series disseminates the findings of work in progress to encourage the exchange of ideas about development issues. An objective of the series is to get the findings out quickly, even if the presentations are less than fully polished. The papers carry the names of the authors and should be cited accordingly. The findings, interpretations, and conclusions expressed in this paper are entirely those of the authors. They do not necessarily represent the view of the World Bank, its Executive Directors, or the countries they represent. Policy Research Working Papers are available online at http:/lecon.worldbank.org.

\footnotetext{
* This study was prepared by Hubert Grignon Dumoulin (Hubert.grignon-dumoulin@.cec.eu.int), Senior Officer at the French Securities and Exchange Commission detached at the EU Commission, and Mogens Kruse (mkr@nationalbanken.dk), Legal Advisor at the Danish Central Bank. The authors are grateful to Jeppe Furbo Ladekarl and his colleagues from the World Bank's Financial Sector Operations \& Policy Department for their assistance and support in the research and preparation of this paper, to Ove Steen Jensen and Karsten Biltoft from Danmarks Nationalbank and to Patrice Aguesse from the French Securities and Exchange Commission for providing comments and suggestions.
} 


\section{Table of Contents}

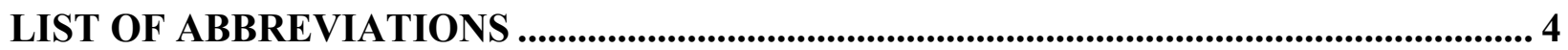

CHAPTER 1 - INTRODUCTION AND BACKGROUND ............................................... 6

CHAPTER 2 - EUROPEAN REGULATORY AND SUPERVISORY FRAMEWORK FOR FIXED INCOME SECURITIES AND MARKETS ..............................................................8

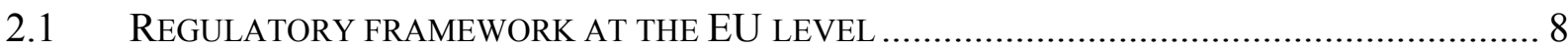

2.2 REGULATORY FRAMEWORK AT THE MEMBER STATES LEVEL …................................. 14

2.3 SUPERVISORY FRAMEWORK AT THE EU LEVEL ....................................................... 15

2.4 SUPERVISORY FRAMEWORK AT THE MEMBER STATES LEVEL ................................... 21

CHAPTER 3 - EU LEGISLATION RELATED TO EUROPEAN ...................................... 23

FIXED INCOME MARKETS ....................................................................................... 23

3.1 PRUDENTIAL RULES ON INVESTMENT IN FIXED INCOME SECURITIES ........................... 24

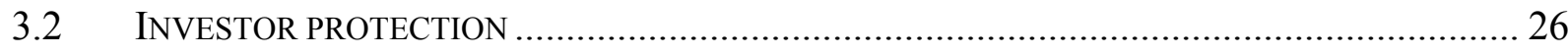

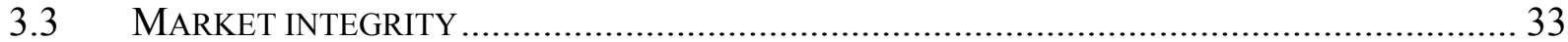

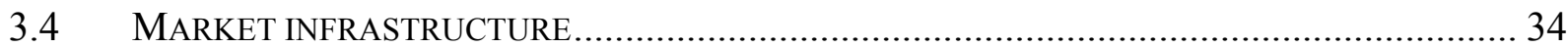

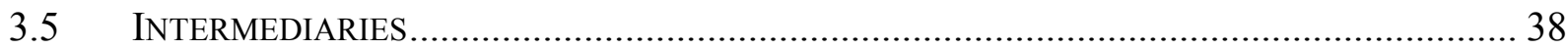

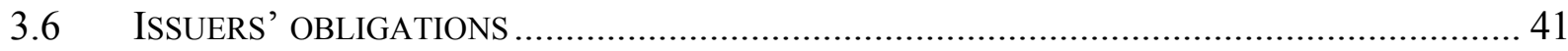

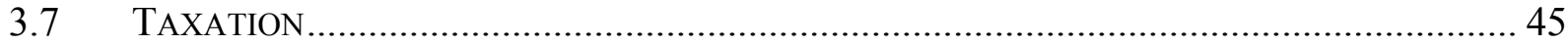

CHAPTER 4 - COUNTRY CASE: FRANCE ................................................................... 47

4.1. THE FRENCH GOVERNMENT DEBT MARKET .............................................................. 47

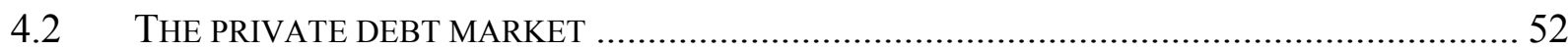

4.3 ORGANIZATION AND SUPERVISION OF THE FRENCH BOND MARKET ............................ 60

CHAPTER 5 - COUNTRY CASE: DENMARK ...................................................................66

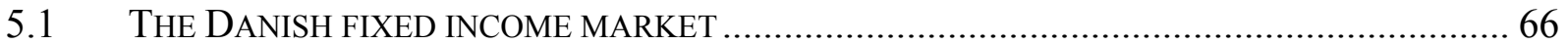

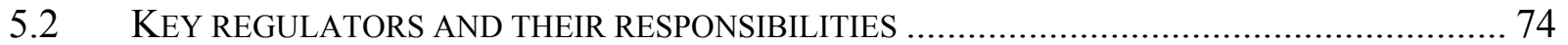

5.3 MAIN REGULATION OF DANISH FIXED INCOME MARKETS............................................ 76

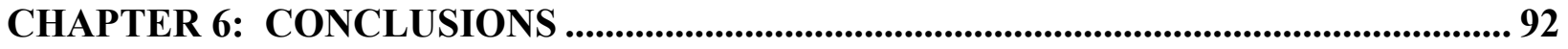

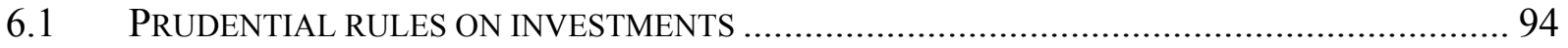

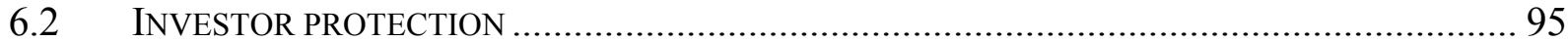

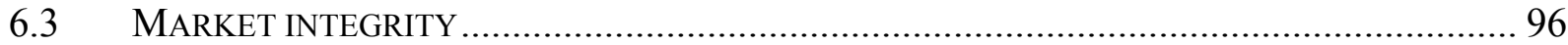

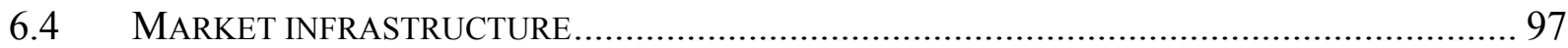

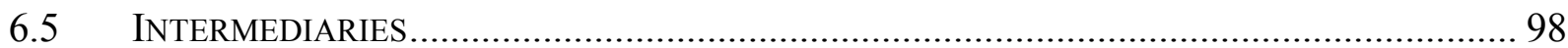

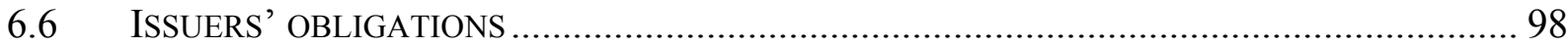

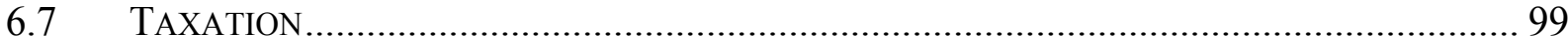

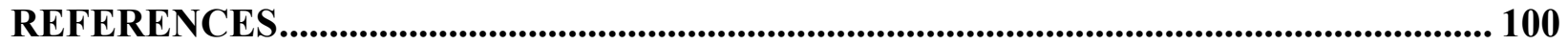




\section{BOXES:}

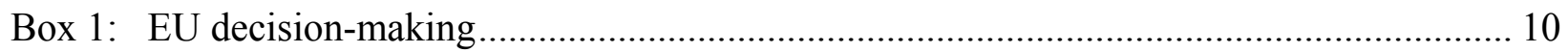

Box 2: The basic regulatory framework for EU fixed income markets........................................ 12

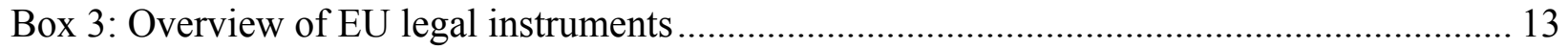

Box 4: European Central Bank cooperation ........................................................................ 19

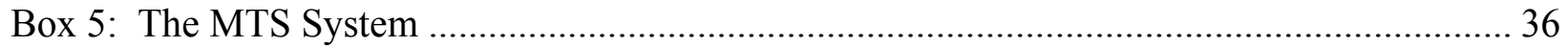

Box 6: Synopsis of regulatory framework for different methods of trade-execution.................. 37

Box 7: Basic features of regulation of investment firms in the 1993 ISD ................................... 39

Box 9: Regulation of Danish MCIs: a historical snapshot....................................................... 82

Box 10: Summary of key European regulatory framework ....................................................... 93

\section{TABLES:}

Table 1: Suggestion for a regulatory framework for different methods of trade execution. ........ 40

Table 2: Figures for 2002 including tap issues (sources: dialogic and bondware)....................... 56

Table 3: Market value of Danish listed bonds by end 2002 ...................................................... 66

\section{ANNEXES}

Annex 1: Terms of Reference for the study (in extract) ………………………..................... 102

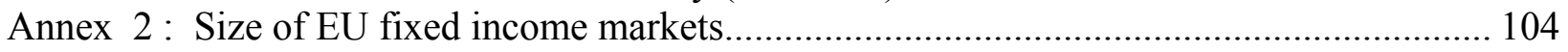

Annex 3: Illustration of the Lamfalussy-decision procedure.................................................... 106

Annex 4: EU regulation of fixed income securities markets ................................................... 107 


\section{LIST OF ABBREVIATIONS}

ATS

CAD

CCP

CESR

CSD

CSE

DKK

ECB

ECOFIN

ECU

EEC

ESC

ESCB

EMS

EMU

ERM

EU

FESCO

FSAP

IAS

ICSD

IORP
Alternative Trading System

Capital Adequacy Directive

Central Clearing Counterparty

Committee of European Securities Regulators

Central Securities Depository

Copenhagen Stock Exchange

Danish Kroner

The European Central Bank

The EU Council of Economic and Financial Ministers

European Currency Unit

European Economic Community

European Securities Committee

European System of Central Banks

European Monetary System

European Monetary Union

Exchange Rate Mechanism

European Union

Forum of European Securities Regulators

Financial Services Action Plan

International Accounting Standards

International Central Securities Depositories

Institutions for Occupational Retirement Provisions 
ISD

MCI

MTF

NCB

OTC

SFP

SRO

SVT

UCITS

U.S.SEC

VP
Investment Services Directive

Mortgage Credit Institution

Multilateral Trading Facility

National Central Bank

Over-the-Counter

The EU Single Financial Market program

Self-Regulatory Organization

Spécialistes en Valeurs du Trésor

Undertakings for collective investment in transferable securities

United States Securities and Exchange Commission

Danish Central Securities Depository 


\section{CHAPTER 1 - INTRODUCTION AND BACKGROUND}

Fixed income securities markets in Europe ${ }^{1}$ have historically been characterized by a number of national markets that were interconnected via the foreign exchange markets. Accordingly, regulation and supervision of fixed income securities markets in Europe was--and to some extent still is--based on national infrastructure, legislation and institutions. Technological progress and the implementation of European Monetary Union (EMU), especially the introduction of euro as the single currency in 1999, are drivers toward more integration of these domestically based markets. To support such integration, European policy-makers have made efforts to adapt the European Union (EU) framework for securities market regulation and supervision.

As regards market integration, on the one hand, early experiences indicate that a euro area $^{2}$ market for fixed income securities is emerging. ${ }^{3}$ A corporate bond market is rapidly developing $^{4}$ and asset securitization is growing. Demand for euro-wide investment products are increasing, traditional patterns in asset allocation are changing, and especially government fixed income markets are moving toward more integrated trading platforms.

On the other hand, although corporate bond markets are still in an embrionic stage, in contrast to the United States, banks are still by far the most important intermediaries on the European capital markets. ${ }^{5}$ Furthermore, there are considerable impediments to the establishment of an integrated European government securities market ${ }^{6}$. Expectations that EMU will lead to a more market-based dis-intermediated financial system in Europe need also to be seen in this perspective.

For many years, the only real pan-European fixed income market was the eurobond ${ }^{7}$ market (international debt securities). Initially, the driving factor behind the development of this

\footnotetext{
${ }^{1}$ Any use of the terms "European," "European Union," "EU" or "EU15" in this Study is a reference to the European Union in its current composition of the following 15 countries: Germany, France, Italy, Holland, Belgium, Luxembourg, United Kingdom, Denmark, Sweden, Spain, Portugal, Finland, Austria, Ireland and Greece. A further 10 countries are set to join the European Union on May 1, 2004: Cyprus, the Czech Republic, Estonia, Hungary, Latvia, Lithuania, Malta, Poland, the Slovak Republic, and Slovenia.

2 Any use of the terms "Euro area," "Eurosystem" or "EU12" in this Study is a reference to the European Union in its composition of the $12 \mathrm{EU}$ countries that has adopted euro as their currency (EU15 except from United Kingdom, Sweden and Denmark).

${ }^{3}$ See Hartmann, May 2003, Santillán, July 2000, or the Giovannini Group, 1997.

${ }^{4}$ See de Bondt, 2002.

${ }^{5}$ See Schinasi, December 1998, or Gros, 2000.

${ }^{6}$ For an analysis of sources of fragmentation in the Euro area government securities markets, see the Giovannini Group, 2000, or the analysis in Chapter IV in IMF, 2001.

${ }^{7}$ During the past 40 years, the eurobond market has experienced exponential growth. Market size - total number of outstanding international debt issues - is estimated to be almost Euro three trillion equivalent. The range of instruments traded has also grown substantially, and now includes debt denominated in euro and many other currencies as well as equity linked debt, global depository receipts, international floating rate notes and Euro commercial paper. As a result, the term "Eurobond" has given way to a wider label for all these forms of borrowing as "international securities." Rather, the appropriate wording should be "Xenobond" in order to stress that the issue is done outside of the country of origin of the issuer. Eurobonds are defined in the EU Prospectus directive (89/298/EEC) as transferable securities that are underwritten by a syndicate from at least two members from
} 
international securities market was the tax regime introduced by the American government in 1963, aimed at discouraging foreign issuers from borrowing from U.S. investors. U.S. tax law also made it difficult for U.S. multinationals to fund their overseas subsidiaries from within the United States. After 1963, however, borrowers wishing to raise debt denominated in U.S. dollars came to Europe, where investors were ready to provide those funds without bearing the burden of taxes. The eurobond market is a self-regulatory Over-the-Counter (OTC) market aimed at wholesale investors and organized by large and world-wide investment banks. However, it is estimated that some five percent of the outstanding amount is held directly by retail investors. Most of the significant size issuance of fixed income securities from European issuers is done on this market, but third- country issuers, notably American, are major participants. All types of maturity of fixed income securities can be found (short, medium and long term) and they cover a wide range of issuers (sovereign, municipalities, public entities, corporate). The linkage with EU regulated markets is done with admission of those eurobonds on specific segments of certain EU stock exchanges (mainly Luxembourg followed by London). Today, anonymity of transactions, a withholding tax exempt regime, and efficient solutions for clearing and settlement of operations $^{8}$ are the three major driving forces of the eurobond market.

As a general observation, for historical reasons, national financial systems in the European Union and their regulatory systems have developed independently from each other, assuming very different configurations in legal systems and traditions. The main characteristics of each of the historically domestic founded European fixed income markets mainly depend on the size of the outstanding public debt and the instruments available for debt refinancing, as government securities historically has been issued on the local market and held by domestic investors. However, sizeable private bond markets exist in some countries (corporate bonds in France and the United Kingdom; mortgage bonds in Germany, Denmark and Sweden; and investment funds in Spain and Luxembourg).

By and large, national financial systems are efficient from member states' domestic perspective. However, a growing demand from pan-European investors to operate across national financial systems increasingly confronts major inefficiencies in trading, clearing and settlement of fixed income securities. As a result, cross-border financial activity in the European Union is still constrained. ${ }^{9}$ Institutional investors are often not internationally diversified. In some countries, they may have a strong preference for equities, and in other countries a preference for government bonds. Pension funds are major players in some countries (e.g., in the United Kingdom and the Netherlands), but not in others (e.g., France and Germany). Also, despite the EU Single Market program for banking and financial services, the regulatory framework is still a source of fragmentation. Thus, differences in market structures still vary in the European Union, both in terms of the instruments used and in the role and importance of financial intermediaries.

different states, and are offered on a significant scale in one or more member states other than the issuer's registered office, and which may be acquired initially only by a financial institution.

${ }^{8}$ The two European international central securities depositories (ICSDs), Euroclear and Clearstream were initially developed mainly to clear and settle eurobond transactions.

${ }^{9}$ For a description of obstacles for cross-border financial activity in the European Union, see the following reports from the Giovannini Group, 1999, and Giovannini Group (2001 \& 2003). 
EMU is not the only force for change on European fixed income markets. Globally, capital markets have experienced huge transformations over the last three decades. The physical location of a market is becoming increasingly irrelevant, as markets turn virtual and intangible. For example, electronic trading platforms are gaining market share in bond trading compared with traditional OTC or stock exchange transactions.

These observations have raised a number of policy issues related to the regulation and supervision of EU securities markets, the supervision of banks and the adequate taxation of savings.

This study describes the current state of the regulatory and supervisory framework for fixed income securities and markets in the European Union. In order to illustrate the great variety of situations among EU member states, this report includes two examples of fixed income markets at the national level: France as an example of a country from the euro area, and Denmark as an example of a country outside the euro area.

\section{CHAPTER 2 - EUROPEAN REGULATORY AND SUPERVISORY FRAMEWORK FOR FIXED INCOME SECURITIES AND MARKETS}

\subsection{Regulatory framework at the EU level}

\subsubsection{Historical overview}

Regulation of financial markets at the EU level has a long history, leading to European Monetary Union. Below is a list of the main elements and operators of this development (in chronological order):

$>$ The idea of a European economic and monetary union first came up about 12 years after the Treaty of Rome was signed on March 25, 1957, founding the European Economic Community (EEC) In December 1969, the EEC agreed to the eventual establishment of an economic and monetary union (EMU) in Europe.

$>$ The three conditions for EMU were stated in the Werner Report of 1970: (1) the total and irreversible convertibility of currencies, (2) the complete liberalization of capital transactions and full integration of banking and financial markets, and (3) the elimination of margins of fluctuation and irreversible locking of exchange rate parities.

$>$ The European Monetary System (EMS), the European exchange rate mechanism (ERM) and the European currency unit (ECU) were established by a resolution of the European Council in 1978 and came into operation in March 1979. 
The Single European Act (the 1985 revision of the Treaty of Rome) set the legal framework for the Single Market Program on establishment of a common European market with free movement of goods, services, capital and people.

In 1992 the Single Market for banking and financial services was formally introduced.

$>$ The Maastricht Treaty (the 1992 revision of the Treaty of Rome) confirmed the three stages of EMU that were recommended in the Delors Report of 1989: During stage one, all candidates for EMU should join the ERM and adopt a narrow 2.25 percent currency band; powers of the Committee of Central Bank Governors and the Council of Economic and Finance Ministers (ECOFIN) should be increased, and the Internal Market should be completed. During stage two, the Committee of Central Bank Governors should be transformed into the European System of Central Banks (ESCB) which consists of a central institution: The European Central Bank (ECB) and the National Central Banks (NCBs) of the 15 EU member states, and its coordination of national monetary policies gradually transformed into a common monetary policy. During stage three ${ }^{10}$ exchange rates would be irrevocably locked and national currencies replaced by a single European currency (euro). The ESCB, the ECB and the NCBs was hereafter entrusted the single European monetary policy and to determine foreign exchange market intervention under the guidance of the ECOFIN.

In 1999, wholesale markets in the euro area converted into euro with immediate impact on money and foreign exchange markets.

The 1999 Financial Services Action Plan was the first EU Commission document to map out a plan for the regulation of securities markets. It was followed by the creation of the Committee of Wise Men chaired by Alexander Lamfalussy in July 2000 , with the mandate to reflect on existing and possible future arrangements related to securities market regulation in the European Union.

In 2002, a new decision-making procedure for regulation of securities markets in the European Union was adopted. As recommended in the 2001 Lamfalussy Report, ${ }^{11}$ this should enable more efficient regulation in order to match the rapid development in the EU securities markets.

\footnotetext{
${ }^{10}$ All 15 member states of the European Union are part of the ESCB. However, three member states of the European Union (United Kingdom, Sweden and Denmark) have decided not to participate in third stage of EMU and thus have not adopted euro as their currency. The 12 member states that have adopted euro as their currency, are normally referred to as the Eurosystem and their geographical scope referred to as the euro area or the euro zone. For a description of the institutional framework for the execution of common monetary policy in EMU, see Gros, 2000.

${ }^{11}$ Report of the Committee of Wise Men.
} 
This development has had major impact on integration ${ }^{12}$ of European fixed income securities markets. Chapter 2.1.2 describes the present institutional framework for regulation of fixed income securities markets at the EU level, and Chapter 2.1.3 introduces the EU regulatory framework that is described in further detail in Chapter 3.

\subsubsection{The institutional framework}

Regulation at the EU level is founded on cooperation between the European Parliament, the Council and the Commission; the latter with an exclusive right of regulatory initiative. The procedures for this cooperation and the necessary voting majority requirements depend on the area of regulation, as defined in the Treaty of the European Union.

\section{Box 1: EU decision-making}

Decision-making at the European Union level is the result of interaction between various parties, in particular the "institutional triangle" formed by the European Parliament, the Council of the European Union and the European Commission. Other European institutions, e.g., the European Central Bank and the Economic and Financial Committee also intervene in many specific areas.

The European Parliament is elected every five years by direct universal suffrage among the 374 million citizens of the European Union. It shares with the Council the power to legislate, i.e., to adopt European laws (directives regulations, decisions). It also exercises democratic supervision over the Commission.

The European Union Council is the European Union's main decision-making body. It is the embodiment of the $15 \mathrm{EU}$ member states, whose representatives it brings together regularly at ministerial level. It is the EU legislative body. For a wide range of EU issues, it exercises that legislative power in co-decision with the European parliament. The rules for this decision-making procedure are laid down in the Treaties and cover every area in which the European Union acts. The Council also coordinates the broad economic policies of the 15 EUs.

The European Commission embodies and upholds the general interest of the Union. The President and the Members of the Commission are appointed by the member states after they have been approved with the European Parliament. The Commission is the driving force in the European Union's institutional system and has the right to initiate draft legislation to the Parliament and the Council. It also acts as the European Union's executive body and as such is responsible for implementing the EU legislation.

These procedures for cooperation have not proved optimal in order to adopt changes to EU securities market legislation. The procedures did not allow for flexibility, as it did not sufficiently differentiate between issues of political nature (that should also in the future be addressed via cooperation) and technical issues (that could be addressed via more simple decision procedures). Therefore, to allow for a more speedy and flexible procedure, in February 2002 a common understanding was achieved between the European Commission and the European Parliament on a new decision-making procedure for regulation of securities markets in

\footnotetext{
${ }^{12}$ The introduction of the euro had an immediate impact on the euro money market; most profound on the unsecured cash market and to a lesser extent on the repo- and short-term securities markets; see Hartmann, 2003, and "The Euro Money Market,” July 2001 (ECB).
} 
the European Union. ${ }^{13}$ (See Box 1.) This so-called "Lamfalussy-procedure" implies that regulation in the future will be decided at different levels:

The EU Council of Ministers and the European Parliament will in principle only be engaged with the central principles of EU securities market regulation (Level 1- framework legislation). Technical implementation measures will be adopted with the European Commission after the vote of the newly established European Securities Committee (ESC). ${ }^{14}$ The detailed implementing measures (Level 2) are part of Community legislation with the same legal force. In addition, a Committee of European Securities Regulators (CESR) has been established ${ }^{15}$ inter $^{2}$ alia to advise the European Commission in the context of preparation of Level 2 measures. This Committee may also adopt standards on areas not covered by Community legislation and furthermore ensure uniform implementation of the Community rules through cooperation Level $3)$.

In 2002 the ECOFIN decided to extend this Lamfalussy procedure to the entire financial area (credit institutions, insurance and pensions, and securities. ${ }^{16}$ ) See Annex 3 for an illustration of the Lamfalussy-decision procedure on securities market regulation

\subsubsection{Regulatory framework}

The main legislative framework relevant for regulation of fixed income markets is the set of provisions on the Single Market for banking and financial services. ${ }^{17}$ A number of EU

\footnotetext{
${ }^{13}$ Initially these new powers of implementation are limited to a period of four years.

${ }^{14}$ The ESC will act in both advisory and regulatory capacities in the field of securities. Acting in its advisory capacity, and in line with the Stockholm Council Resolution, the ESC will be consulted by the Commission on policy issues, in particular, but not only, for measures the Commission may propose at Level 1. In order to ensure close links between both committees, the chairperson of the CESR will participate at the meetings of the ESC as an observer.

Subject to specific legislative acts proposed by the Commission and adopted by the European Parliament and the Council, the Securities Committee should also function as a regulatory committee in accordance with the 1999 Decision on comitology to assist the Commission when it takes decisions on implementing measures under Article 202 of the EC Treaty.

The Commission will inform the European Parliament on a regular basis of the ESC's proceedings acting under its regulatory capacity. It will send it at the same time and on the same terms as to the members of the ESC, the agendas for Committee meetings, the results of any votes and the summary records of meetings, as well as the list of the authorities to whom the representatives of the member states belong.

${ }^{15}$ The CESR is established as an independent committee of European securities regulators. All undertakings, standards, commitments and work agreed within the Forum of European Securities Commissions (FESCO) will be taken over by the CESR. The role of this Committee is to: (a) improve coordination among securities regulators; (b) act as an advisory group to assist the European Commission, in particular in its preparation of draft implementing measures in the field of securities; and (c) work to ensure more consistent and timely day-to-day implementation of Community legislation in the member states.

The Committee was established under the terms of the European Commission's decision of June 6, 2001 (2001/1501/EC). Each of the 15 member states of the European Union has one member on the Committee. The members are nominated by the member states and are the heads of the national public authorities competent in the field of securities.

Furthermore, securities authorities of Norway and Iceland are also represented at a senior level.

For further information on CESR, see Section 2.3.2.

${ }^{16}$ The extension of the procedure to cover EU regulation on investment funds (UCITS Directives) is expected to take place later this year.
} 
Directives have been adopted to ensure the development of a single securities market for both new issues and trading of securities. In short, they regulate the initial and on-going conditions for securities market intermediaries (investment firms), establish requirements for the issuance of securities (both as regards public offers of securities and requirements for securities to be listed on a stock exchange) and coordinate the conditions applicable to investment funds (UCITS). The conditions for setting up investment firms and their on-going business are similar to those for banks, and provide for a level playing field between non-bank investment firms and banks providing investment services. The legislation on issuance of securities lays down minimum requirements for the information that must be disclosed to the public and facilitates cross-border issuance of securities. The legislation on investment funds facilitates the distribution of units of such funds across the European Union.

The single market for banking and financial services relies on the building blocks of home country control and mutual recognition. Under these principles, a financial operator (a bank, an investment firm, etc.) that is operating in another member state (host country) continues to be supervised by the authority in the country of origin (home country). Any financial operator incorporated in a member state may, directly or indirectly, provide services across EU borders on the basis of a single license ("EU passport") issued by the home country authority and under its control. However, several areas, in particular those relating to consumer protection, competition and other conduct-of-business rules, continue to be covered by the host country's rules.

\section{Box 2: The basic regulatory framework for $E U$ fixed income markets}

The regulatory framework of the single securities market for issues and trading in securities is to a large extent determined by the following "core" directives (a detailed list is available in Annex 4):

The 1993 Investment Service Directive (ISD)

The legislation on Investment Funds (UCITS)

The 2003 Market Abuse Directive.

In banking, the regulatory framework is to a large extent determined by the First (1977) and Second (1988) Banking Directives, which are now integrated in the Directive relating to the taking-up and pursuit of the business of credit institutions (2000).

Despite successful implementation of the ISD and the UCITS Directives, legal obstacles to integration of financial services has continued to exist. Therefore, in 1999 the European Commission identified a number of areas in which action was required in order to complete integration of financial services. This took the form of the Financial Services Action Plan (FSAP), covering policy initiatives to be implemented by 2005 in the areas of financial law, regulation, supervision and taxation. So far two Directive proposals, one on market abuse, and one on prospectuses, have been introduced under the Lamfalussy-decision procedure (see Chapter 2.3.2).

\footnotetext{
${ }^{17}$ Legal basis in the Treaty of the European Union: Articles 44, 47 para 2, and 95.
} 
Parallel to the core securities market legislation, also certain general conditions have to be fulfilled in order to achieve integration in capital markets, for example with regard to company law, provision of financial information and taxation of savings income. Such general framework legislation is outside the scope of this study, but is described below in short in order to give a more complete picture of present regulatory initiatives with impact on European fixed income securities markets.

First, very few truly cross-border firm structures exist at present, but this may change following the recent political agreement on the establishment of a European Company Statute (2001). This will give companies (including banks) operating in more than one member state the option of being established as a single company under Community Law and operating on the basis of one set of rules throughout the European Union. Second, the recently adopted regulation (described in Chapter 3.6.2.1) requiring listed companies (including banks) to prepare consolidated accounts in accordance with the International Accounting Standards (IAS) from 2005 onwards will result in more reliable and transparent accounts, thereby reducing barriers to cross-border trading. Third, a draft EU Directive on takeover bids is presently discussed with the European Parliament. Finally, divergent taxation rules for savings remain a significant hurdle to further integration. An agreement (described in Chapter 3.7) has recently been reached on the exchange of information on savings held by residents from other members states, but a long transition period is scheduled.

The core remedies available for EU securities market regulation are Directives and regulations. Minimal harmonization is done through directives, which are EU legal instruments that need to be transposed into national law by each member state. Regulations are instruments that are directly applicable in the member states, but they are less often used for market integration. (See Box 3.)

\section{Box 3: Overview of EU legal instruments}

The most important EU legal instruments are:

Regulations are binding on all member states and shall be applied directly

Directives are binding upon member states in terms of their objective, but it is left to national authorities to decide the form and means for implementation.

Resolutions are binding in their entirety upon those to whom they are addressed

Recommendations and opinions are not binding, but national authorities may be obliged to take them into consideration in their interpretation of related legal issues.

So far, in EU securities market regulation only essential rules have been harmonized; thus leaving the bulk of regulation subject to mutual recognition. As an example, the first banking and insurance directives were based on minimum coordination, leaving room for each of the EU member states to impose additional and more stringent national rules. Due to this as well as on the various interpretations developed by member states on the scope and content of some 
securities market directives, this may lead to lack of real convergence or common market practice.

As a general trend, EU securities market legislation is developing toward a higher level of harmonization (in certain cases even full harmonization, e.g., IAS and the 2003 prospectus directive).

From a regulatory point of view, the single market for intermediaries on EU capital markets is almost complete. With the exception of pension funds ${ }^{18}$, EU markets have been opened up for the free provision of banking, investment and insurance services with a single license. The liberalization was implemented in different phases: in 1993 for banking, in 1994 for insurance and in 1996 for investment services. This also applies to foreign-owned institutions. The EU thus offers effective market access, which goes even further than the national treatment provided in the World Trade Organization (WTO) framework.

The same cannot be said as regards the EU regulatory framework for financial markets and products. It applies mainly at retail level, but also to some extent at the wholesale level, or has implications for the latter. Differing regulations at retail level can hamper securitization of products and thus affect the wholesale level. Apart from investment funds, common rules for securities emissions, initial public offerings and stock exchange listings have been much less developed. Although legislation is in place, harmonization has gone insufficiently far and implementation leaves much to be desired to make mutual recognition work. These insufficiencies are the key drivers behind the before mentioned 1999 EC Commission Financial Services Action Plan.

Therefore, to give a more complete picture, this study of the regulation of fixed income securities markets in Europe refers to current legislation, current legislative proposals and selected suggestions for further reform of the EC regulatory framework (Chapter 3) as well as examples of the regulatory framework at the member states level (Chapter 4 and 5).

\subsection{Regulatory framework at the member states level}

The residual regulatory framework for fixed income securities markets (compared with regulation at EU level) remains at member states level.

Different European financial systems have resulted in different regulatory answers. A market-based system is mainly regulated on the basis of market information, accounting standards and market integrity, whereas a bank-based system is mainly regulated on the basis of safety and soundness of the banking sector. Any market regulation is a trade-off between safety and efficiency. Some European market regulators have very strong focus on ensuring fairness and transparency, while others put greater emphasis on ensuring market efficiency and liquidity.

\footnotetext{
${ }^{18}$ From 2005 the 2003 EU Pension Funds Directive will allow pension funds to manage occupational pension schemes for companies established in another member state and allow a pan-european company to have only one pension fund for all its subsidiaries all over Europe. Creation of an EU Internal Market for pensions also requires the removal of fiscal barriers and barriers to the transferability of pension rights. Recent initiatives have also been taken by the Commission in this respect.
} 
Also, some EC legislation may differ somewhat from one member state to another due to different implementation techniques ${ }^{19}$ for transposition of EC directives (see Box 2) at the member state level. As an example of this, the legal definition of fixed income financial instruments in the 1993 EC Investment Services Directive is not uniform among the 15 EU member states (due to different variants of debt securities including secured money market instruments).

Finally, also the institutional framework may differ significantly from one member state to another. For example, in member state 1, listing rules may be set by the domestic securities regulator, and clearing and settlement rules set by the domestic central bank. In member state 2 listing rules are set by the domestic stock exchange, and clearing and settlement rules are set in cooperation between two domestic securities regulators.

\subsection{Supervisory framework at the EU level}

There is no supervisory framework at the European Union level in the securities area. Any attempt to compare the EU situation with the United States federal system of securities market supervision is simply not relevant. ${ }^{20}$ Until recently, only few voices raised the question of the opportunity of supervision at community level of securities markets. Neither the European Parliament nor the Council or the European Commission has officially expressed such a need.

Therefore, supervision of fixed income securities and markets is today left at national level. Describing the situation in each EU member states would result in a difficult exercise of comparative law. The situation is very heterogeneous not only at the EU level but also at national level.

Though, there is no supervisory framework at the European Union level, it is, however, worth describing the interesting recent developments following the publication of the Lamfalussy report, notably the creation of the Committee of European Securities Regulator. Moreover, certain persons are nowadays advocating the creation of European securities supervisor.

\subsubsection{Findings and recommendations of the Lamfalussy report ${ }^{21}$}

In July 2000, the European Union's economic and finance ministers requested to a committee of seven members to reflect on the existing and possible future arrangements related to the regulation of European securities market. This Committee was asked notably:

\footnotetext{
${ }^{19}$ Examples of techniques for implementation of an EU Directive into national law: (1) via a detailed national law approved by parliament, (2) via a general habilitation granted to either finance minister, central bank, securities regulator/supervisor, SRO or a stock exchange, (3) via detailed rules either at the level of finance minister, central bank, securities regulator/supervisor, SRO or exchanges, or (4) via contractual rules of private bodies if there is a specific habilitation in national legislation.

${ }^{20}$ For an analysis of securities market supervision in Europe, see Karel Lannoo: Does Europe Need an SEC? Securities market regulation in the European Union (1999), European Capital Markets Institute.

${ }^{21}$ Report of the Committee of Wise Men.
} 
- To assess the current conditions for implementation of the regulation of the securities markets in the European Union

- To assess how the mechanism for regulating of the securities markets in the European Union can best respond to developments under way on the securities market

- To propose scenarios for adapting current practices in order to ensure greater convergence and cooperation in day to day implementation and take into account new developments on the markets.

The fixed income securities were also in the scope of the Lamfalussy report notably corporate and government bonds but also market infrastructure (regulated markets, OTC markets and alternative trading system). However, the request did not refer to possible discussion on future reform of the supervision regime in the European Union and prudential supervision was explicitly excluded, notably at the request of the European Central Bank. Certain member states would have opposed to such inclusion in the mandate. Therefore, the terms of reference indicated that the Committee should "take into account the existing institutional framework" and should focus its discussion on the practical arrangements for implementation of securities community legislation notably by adjusting the cooperation between national securities regulators.

In its initial report published in November 2000, the Committee indicated that it believes that there are good reasons for not considering the establishment of a single regulatory agency. This solution would be envisaged only if the other approaches - notably cooperation between national securities regulators and supervisors - did not appear to have any prospect of success. In the final report published in February 2001, the proposal for a single regulatory agency is described as impractical under the present circumstances. It is worth mentioning that one member of this Committee would have supported a more ambitious approach but it was felt that all the conditions were not yet present for a recommendation for radical reform by creation of a European securities agency. It was also indicated that it might need modification of the EU Treaty to introduce such an agency. Therefore, in the Lamfalussy report, rationalization and convergence of regulatory and supervisory functions at national level is encouraged. One of the difficulties mentioned is the large number of authorities in charge of supervision and regulation of securities markets that creates unnecessary cost and confusion among market players. It is stated that there are approximately 40 regulatory organizations, far too many for an efficient system. Member states were encouraged to establish only one entity at national level with similar functions and powers. One of the recommendations was also the setting up of a new committee of European securities regulators for the purpose of the regulatory reform but also for the strengthened cooperation between themselves.

\subsubsection{Actions already taken following the endorsement of the Lamfalussy report}

Following the endorsement of the Committee of Wise Men recommendations in Stockholm Council in March 2001, the European Commission adopted two proposals end of May 2001: the market abuse Directive and the prospectus Directive. The two texts, two priority 
actions of the Financial Services Action Plan ${ }^{22}$, were drafted following the new regulatory approach described in the Lamfalussy report.

On the supervision aspect, for the first time in securities Community legislation, provisions related to the minimum powers of the competent authorities were included, respectively in Article 12 and 21 (notably possibility to require information and documents, suspension and prohibition of trading, scrutiny of information, etc.). The same approach has been used for the new proposals for an Investment Services Directive adopted in November 2002 (Article 46) and for a Transparency Obligations Directive adopted in March 2003 (Article 20). Such approach should normally contribute to greater convergence and harmonization of functions and powers of national supervisory authorities. In previous or existing EU legislation related to the financial markets, it was only required that member states should ensure that their national competent authority or authorities have the powers necessary to carry out their task. The detailed list of powers attributed to competent authorities was left to national legislation. Nowadays in its new proposals, the Commission has introduced a minimum list of rights for competent authorities in order to ensure consistency in the day-to-day application of Community legislation. Inputs from the IOSCO Report of September 1998 on "objectives and principles of securities regulation" 23 were used for the purpose of the definition of this minimum list of detailed powers.

Furthermore, the Commission has tackled the issue of the too numerous authorities within the European Union. In both market abuse and prospectus proposals, the principle of establishment of a single administrative competent authority to ensure application of the two directives was introduced. In the context of the prospectus proposal, the Council has agreed to a transitional period of five years for the maintaining of several competent authorities in a given member state. The issue of independence of the supervisory authority was also addressed by reference to the administrative nature of such authority. Exercise of powers or possible delegations of tasks to other entities differ in each text because of the different nature of the functions to be performed and because of the need to avoid conflict of interests. Nevertheless, different limits or safeguards are mentioned. The same approach is included in the proposal for a transparency obligations directive, where the competent authority must be the one designated for ensuring the functions provided in the prospectus directive (see Chapter 3.3.3)

The Lamfalussy report has also led to a significant reinforcement of the network system of those competent authorities. In December 1997, 17 competent authorities of EEA signed a multilateral convention, and as a consequence, the Forum of European Securities Regulators (FESCO) was created. It was the first official pan-European network of securities regulator and supervisor. In conformity with its charter, FESCO oriented its work towards operational tasks. Beside elaboration of common standards not covered by Community legislation, FESCO was designed also as a pan-European network in order to strengthen their cooperation, notably in the field of market surveillance through the creation of FESCOPOL with the signature of a multilateral memorandum of understanding. However, FESCO is not a Community institution

\footnotetext{
${ }^{22}$ Communication of May 11, 1999 from the European Commission "implementing the framework for financial markets: action plan" identifies a series of 42 measures that are needed in order to complete the single market for financial services.

${ }^{23}$ IOSCO Objectives and Principles of Securities Regulation.
} 
but was able to create what could be described as the first stone for an EU supervisory body. In March 2001, the Stockholm European Council resolution endorsed the Lamfalussy report and its new regulatory approach. In June 2001, the European Commission established two committees, the European Securities and the Committee of European Securities Regulators by two separate decisions. The later is replacing FESCO as an independent Committee where the European Commission is only observer. It is not a Community institution like FESCO but the previous role of FESCO has been officially recognized by the European Commission, the Council and the European Parliament in its resolution of February 5, 2002 on the implementation of financial services legislation. Therefore, despite the EU regulatory framework (arrangements described in another section), CESR is currently the European Union recognized network of national supervisory authorities in the securities field. However, its scope is limited to coordination and cooperation aspects with very limited binding force and no possibility to overrule national legislation. CESR has also an explicit role for supervision of the consistent transposition of Community legislation in the securities field without prejudice to powers of the European Commission on this matter.

\subsubsection{Other initiatives from the European Central Bank}

The Treaty establishing the European Community does not give a role to the European Central Bank (ECB) for supervision of securities markets or specific right to intervene in the definition of the supervisory framework of securities market. The primary objective of the ESCB is to maintain price stability. However, the ECB is following closely all EU initiatives in the securities field because of the growing importance of capital market financing of the economy, of the interaction with certain ECB activities (notably access to payment system for clearing and settlement activities) and of the overall concern on financial global stability.

Article 105 of the Treaty asks notably the ESCB to promote the smooth operation of payment systems and to contribute to the smooth conduct of policies related to the financial stability of the financial system. ECB is represented in certain EC committees or working groups involved with securities markets EU policy. ${ }^{24}$

A recent and interesting initiative of the ECB is related to a particular segment of European fixed income securities markets: the short term paper segment. A group of major market participants (Euribor-ACI ${ }^{25}$ ) is currently working on a definition of a pan-European market for short-term paper (treasury bills, certificates of deposits and commercial paper of an initial maturity of less or equivalent to one year). This is a private initiative led by major credit institutions. It is intended to cover all traditional aspects of a securities market (documentation and disclosure obligations of issuers, reporting of transactions, index definition). The approach is purely contractual by adhesion of interested issuers to participate to such market and their

\footnotetext{
${ }^{24}$ The ECB is an observer in the European Securities Committee; ECB and the 15 EU Central Banks are participants in the CESR/ESCB joint working group on clearing and settlement; and the ECB deliver opinions on certain European Commission proposals for a Directive or a Regulation (notably on the market abuse and the prospectus proposals adopted by the Commission in May 2001).

${ }^{25}$ ACI- The Financial Markets Association was founded in France in 1955 following an agreement between foreign exchange dealers in Paris and London. The task force on the euro short term securities paper was launched since the ECB Money Market Contact Group, an informal forum established by the ECB, considered insufficient the integration of those markets.
} 
acceptance of those rules additional to the Community and national one. However, this group felt necessary to have an oversight body able to ensure the functioning and the maintenance of these contractual arrangements. The ECB is ready to accept such role and is heavily involved in the process started by the market participants. With such a system, the ECB would be come de facto the supervisory entity at the EU level of short term fixed income securities, while national regime would be maintained but member states will be under heavy pressure to align it on the contractual pan-European rules if this market reaches the critical size. ${ }^{26}$

\section{Box 4: European Central Bank cooperation}

The European Central Bank (ECB) was established on June 1, 1998. Its highest decisionmaking body is the Governing Council (the six Members of the ECB Board and the governors of the 12 national central banks of the euro area. Its key task is to formulate the monetary policy of the euro area. Specifically, it has the power to determine the interest rate at which commercial banks may obtain liquidity (money) from their central bank. The Executive Board of ECB is responsible for implementing the euro area monetary policy and manages the day-to day business of the ECB. The third decision-making body of the ECB is the General Council (the President and Vice-president of the ECB Board as well as the governors of the national central banks of the $15 \mathrm{EU}$ member state). It contributes to the advisory and coordinating functions of the ECB and to the preparations for the possible enlargement of the euro area.

The European System of Central Banks (ESCB) is composed of the ECB and the national central banks of all $15 \mathrm{EU}$ member states. Among its tasks are promotion of the smooth operation of payment systems, review of developments in the banking and financial sector, and to promote a smooth exchange of information between the ESCB and supervisory authorities.

The Eurosystem is a term chosen by the ECB to describe the arrangements by which the ESCB carries out its tasks in the euro area. The term is necessarily as long as there are EU member states that has not adopted the euro as their currency (currently: United Kingdom, Sweden and Denmark). The primary objective of the Eurosystem is to maintain price stability.

As a European institution, the ECB has a reciprocal relationship with the EU Council (see Table 2). The EU Council president may take part in meetings with the ECB Councils, and the president of the ECB is invited to participate in EU Council meetings on subjects relating to the tasks and objectives of the ESCB (= ECOFIN Councils and meetings of the Eurogroup, which are meetings of the ministers of economics and finance of the euro area countries). Also, a member of the European Commission has the right to participate in ECB Council meetings. Finally, the ECB (and the 15 EU national central banks) also participate in the Economic and Financial Committee; a consultative Community body which deals with a broad range of European economic policy issues.

The legal basis for the ECB and the ESCB is the EU Treaty and its protocol on the Statute of the European System of Central Banks and The European Central Bank.

Source: ECB's homepage at http://www.ecb.int/home/home01.htm

\footnotetext{
${ }^{26}$ For further information on the background for these efforts, see ECB (2001) "The Euro Money Market."
} 


\subsubsection{Other initiatives for a more ambitious EU supervisory framework}

During the negotiations in the Council's working group on the prospectus proposal for a Directive, the German delegation felt it necessary to ask for the creation of a European Union entity responsible for the approval of prospectuses in the context of cross-border offers or multiple listings. Such an entity would have offered an even more operational answer to the functioning of primary market operations on a cross-border basis within the European Union. This proposal was officially presented at the Council level by the German Finance Minister, $\mathrm{Mr}$ Hans Eichel in June 2002. However, this initiative was not supported by other member states and the only concession to the German proposal has been the inclusion of a recital in the common position of the council for a prospectus Directive. It refers to the possible establishment for a European securities unit in the future. However, it does not create any kind of commitment for the future.

It is also worth mentioning some private initiatives calling for an EU supervisory framework not only based on coordination and cooperation between national competent authorities. Even if they do not address the precise details of a future architecture for a European supervisory level, the basic reasoning is that a more centralized and more ambitious system is necessary for industry. Certain operational aspects have been tackled, such as a pan-European information system and/or dissemination system for corporate disclosure. The reason is also that coordination and cooperation will not be sufficient to provide enough legal consistency and certainty for market participants involved in cross-border business. Large investment banks located in London have raised concerns that the proposed supervisory framework will not be able to cope with their practical needs. Major German banks have also pushed for more ambitious solutions (cf. Supra). With a different approach, a French think-thank, Eurofi 2000, is advocating that the European convention should address the issue and pave the way for a system comparable to the one set up for the introduction of the euro currency. A group led by Sir Nigel Wicks intends to federate the views of the City of London in order to counterbalance this French initiative, but also to prepare future policy in this area.

The description of the supervisory framework does not address the issue of possible European Self-Regulatory Organization (SROs). For the time being, no one really raised the question of whether or not such organizations are necessary at the EU level. Several reasons might explain why this debate is not relevant. Community legislation is addressed to member states and not directly to public competent authorities or SROs. The situation is very heterogeneous at the EU level concerning the recourse to SROs in member states. There are member states without SROs where there is at least a securities regulator in each member state. It was possible to create a European forum of securities commissions where the equivalent for SROs do not exist and would be very difficult to achieve. There is more and more convergence between the role and the tasks performed by national securities regulators where SROs are not in a position to redefine their role and to negotiate at international level. Moreover, there is a growing trend to suppress or restructure SROs following demutualization of stock exchanges. 


\subsection{Supervisory framework at the member states level}

The current structure of supervision of EU fixed income securities markets at national level is very heterogeneous. This part does not intend to present the situation in each member state. The two country cases on French and Danish fixed income securities markets (cf. Infra) provide two detailed examples of supervision regime in two EU member states. However, some broad common characteristics exist.

The supervision regime differs depending on the nature of the issuer (sovereign, municipalities, banks and corporate), on the nature of the fixed income securities (short, medium, long-term initial maturity), on the nature of the offer (private placement or offer to the public of securities) and on the nature of the markets (exchange trading, OTC trading, alternative trading systems and trading platforms). Other elements in the regulatory environment, which are closely related to securities laws, explain also the difference of supervisory framework at national level, notably accounting standards, company laws and taxation.

Each national regime makes use of traditional actors in the context of securities markets: i.e., ministry of finance/treasury, central bank/banking supervisors, securities regulator and supervisor, exchanges/trading platforms. It is also important to note the strong influence of market participants practice for certain EU fixed income securities markets, notably the eurobonds or the euro commercial paper segments.

The importance of the ministry of finance and the treasury at the national level in fixed income securities market derives from the necessity to finance of public deficits. In most member states, the main segment of the fixed income securities market is the sovereign debt. Generally, it is the benchmark for the other segment of bond issues and a deep and liquid sovereign market is a precondition for creating other efficient corporate debt market. However, there is a growing trend at national level to avoid mixing supervisory functions with the practical organization of the sovereign debt market. This split of functions intends to avoid conflict of interests and is seen by market participants as an important element for investor protection. In most member states, ministries of finance and treasuries are no longer in charge of daily supervision of these securities market and not involved in the process of drafting the detailed related legislation because they are seen as market operators. Their main tasks are limited to definition of their issuance program and the marketing of the different issues and assess new proposals for a better efficiency of their markets.

In all member states, there is a securities commission. Sometimes, it was the result of the transposition of certain EU directives related to securities law, where an appropriate body was necessary to ensure correct application of the provisions. In comparison with the U.S. Securities and Exchange Commission (SEC), European securities commissions were created much later, in general in the 1980s or early 1990s. It should be noted that their competence and powers are generally more limited and not comparable. Some commissions are comparable to the U.S. SEC (for example in France or Italy); others share their powers with the national stock exchange (for example in Germany or Luxembourg), or other authorities (for example in Ireland) with the 
central bank. The dividing line between regulation and self-regulation also differs importantly from country to country.

The involvement of central banks is also an important element in the context of supervision of fixed income securities market. One of the reasons is a lower recourse to market financing compared to credit and loans. Europe has a strongly bank-based system where the U.S. makes greater use of a segmented and market-based financial system. Historically, central banks would be designated as de facto securities market supervisors in the absence of a specific body. However, there is a growing trend to see day-to day supervisory functions removed in favor of the national security supervisor/regulator. There is only one member state where the central bank is empowered with the supervisory functions deriving from the securities Community legislation. Central banks thus tend to concentrate on assessing and promoting overall efficiency and stability of securities markets and payment systems. However, it is important to note for an important part of fixed income securities markets (government bonds and money market instruments), the involvement of central banks is greater because national legislation may designate those entities as responsible or co-responsible for market supervision of those segments.

Historically, most member states have relied on domestic providers of clearing and settlement services to support issuance and trading of fixed income securities. These providers may be organized as banks in some countries, as investment service firms in other countries, and as public entity service providers (e.g. in-house functions of a central bank) in other countries. Depending on national situation, domestic central banks might be directly involved in the daily functioning and organization of their national securities settlement systems (most often operated by the central bank or by a domestic Central Securities Depository (CSD). In other countries, the central bank is only involved as provider of settlement asset and/or as overseer of clearing and settlement functions. Therefore, also in this context the organization of supervision is not homogeneous in Europe. Presently, significant efforts are made to allow for easier and cheaper clearing and settlement of cross-border securities transactions in Europe. Among these efforts is an on-going cooperation between European securities supervisors (via CESR) and EU central banks (via ESCB) on how to organize cooperation between supervisors and overseers of providers of securities clearing and settlement services in Europe. ${ }^{27}$ However, as also referred to under the competences of CESR in Chapter 2.3.2, its scope is limited to coordination and cooperation aspects with very limited binding force and no possibility to overrule national legislation.

The involvement of banking supervisors is indirect but also an important element in the context of supervision of fixed income securities market. The main market participants to these markets are credit institutions and therefore under prudential supervision. Investment firms in Europe are generally subsidiaries of large commercial banks.

Another element that must be noted is the evolution of the traditional role of stock exchange. Most of EU stock exchanges have been through a demutualization process and are now for profit organizations. They are less and less private entities entrusted with certain public

27 A public consultation is scheduled for end of July 2003 with, inter alia, a suggestion for a standard on cooperation between securities regulators, -supervisors and -overseers. 
good functions that may justify monopoly on securities transactions and the fact that they could perform certain supervisory tasks. It can be noted that the three major European Stock Exchanges (London Stock Exchange, Euronext and Deutsche Börse) are already public and listed companies. Stock exchanges are less and less willing to ensure supervisory functions in order to concentrate their resources on their core business, and similarly governments are less and less willing to leave public service functions with for-profit organizations. Besides, in most member states, trading in fixed income securities markets take place outside the exchange itself and the only remaining link with the exchange is the listing function. Member states were also bound to reorganize the supervision and the regulatory functions traditionally held by the exchanges following the demutualization process in order to avoid conflict of interest and maintain confidence in market functioning. Market trends such as concentration and mergers of exchanges but also arrival of new competitors such as trading platforms called for reform. It has led to a reinforcement of supervision powers to the benefit of securities regulators and to the detriment of exchanges or SROs. Trading platforms such as MTS (see Chapter 3.4.1) or Brokertec, which are taking a growing market share in the trading of fixed income securities, are generally not covered the same way compared to exchanges by the supervisory framework at national level. Trading platforms provide a core investment service and therefore are caught most of the times under the regulation for investment firms for brokers-dealers but not always by the one for exchanges. They generally do not want to encompass the whole traditional functions of an exchange and will limit their operations in order to avoid to be recognized as an exchange. However, some trading platforms are operated by recognized exchanges at national level (for example in United Kingdom and in Italy).

\section{CHAPTER 3 - EU LEGISLATION RELATED TO EUROPEAN FIXED INCOME MARKETS}

This chapter describes the overall regulatory regime laid down in the relevant EUdirectives. As capital markets are an essential element for financing the economy, since its establishment the European Commission has made several legislative proposals in order to contribute to the build of a single European market in financial services and to favor market integration. Most of these initiatives have taken the legal form of Directives but other approaches are also possible (Regulation or Recommendations for example). The different existing Community texts with fixed income securities markets in their scope are described below. It presents also the current different proposals that are under negotiations at European Parliament and Council level. The presentation of those texts is organized following their main objective. However, such classification might be considered as a bit simplistic due to the fact that a given legislation might encompass several of the listed objectives.

Securities market regulation can be divided in two parts: regulation of the intermediaries that are active in these markets, and regulation of the markets themselves. While the objectives of regulation in both cases are the same - protection of depositors and investors and the maintenance of market stability - this has proved easier to address for intermediaries than for markets. For intermediaries the key issues are control of the solvency of the intermediary. Commonly agreed rules on minimum solvency ratios for banks and investment firms have been in place in Europe for years. 
For securities markets, by contrast there is lesser consensus on common rules to serve the objectives of regulation. The International Organization of Securities Commissions (IOSCO) has promoted agreement on global principles ${ }^{28}$ for market integrity and surveillance. However, much discretion is left to national regulators in their interpretation of these principles.

Thus, as an overall observation, European securities market regulation has to some extent been harmonized at EU-level. The current EU securities market regulation concern basic rules for issuers on EU capital markets, rules on stock exchange listing admission, disclosure and trading rules, regulation of market infrastructure and intermediaries, and investment products. Each of these areas is explained in more detail in this chapter.

Much of the core of this securities market regulation is currently being revised. Therefore, we have referred in this chapter to the present EU regulatory framework as well as to current Commission proposals for revision of it.

\subsection{Prudential rules on investment in fixed income securities}

\subsubsection{UCITS Prudential rules on investment in fixed income securities}

Community legislation on the coordination of laws, regulations and administrative provisions relating to investment funds (in EU-terminology: UCITS - undertakings for collective investment in transferable securities) was first adopted in December 1985 (since then, it has been modified and completed at five occasions). ${ }^{29}$ One of the aims of this EU legislative text is to ensure effective and more uniform protection for unit-holders. Notably, this Directive deals with certain prudential rules related to investment policy. There is an obligation for fund managers to enter into diversification of financial assets held by UCITS (Article 19 to 26 of modified UCITS Directive (85/611/EEC). The economic rationale of such diversification of assets is the limitation of risks for investors. Fund managers are required to enter into a minimum diversification of investments but also need to invest in securities of different issuers. However, this diversification is adapted depending on the nature of the UCITS (for example money market funds compared to equity funds).

A UCIT is not entitled to invest more than five percent of its assets in transferable securities or money markets instruments issued by the same body (the UCITS Directive has a broad definition of money market instruments but most of them, such as Treasury bills, certificate of deposits and commercial paper, have the form of transferable securitized debt with a short initial maturity). This threshold might be raised to ten percent at national level upon a 40 percent ceiling condition (Article 22(2)). However, Community legislation contains options for member states to opt for a differentiated regime for fixed income securities compared to equity and also for certain type of issuers. It may create a clear incentive for fund managers to invest in those securities, the rationale being that there is lower risk profile for those securities and less

\footnotetext{
${ }^{28}$ IOSCO Objectives and Principles of Securities Regulation.

${ }^{29}$ Directive (85/611/EEC) of December 20, 1985, Directive (88/220/EEC) of March 22, 1988, Directive (95/26/EC) of June 29, 1995, Directive (2000/64/EC) of November 7, 2000, Directive (2001/107/EC) of January 21, 2002 and Directive (2001/108/EC) of January 21, 2002.
} 
probability of default. This differentiated approach is also broadly in line with the traditional hierarchy of spreads that can be found in fixed income securities market and ratings assigned to such issuers.

A member state may raise the five percent limit to a maximum of 35 percent in the case of sovereign debt securities (Article 22(3) of UCITS Directive). The same approach has been retained in the case of covered bonds (e.g. mortgage bonds) where a member state may raise the five percent limit to a maximum of 25 percent (Article 22(4)). ${ }^{30}$ Therefore, UCITS Community legislation implicitly recognizes the less risky character of mortgage bonds compared to other corporate bonds because of their privilege in case of insolvency and the collateral in place. Community legislation also authorizes member states and their competent authorities to derogate from Article 22 in the case of sovereign debt securities. A member state may introduce the possibility to have a UCIT with 100 percent of its assets invested in one sovereign issuer with at least six different issues and any one issue should not account for more than 30 percent of its total assets (Article 23(1). With those elements, member states may introduce important incentives to create deep and liquid fixed income securities markets in the case of sovereign and mortgage bonds issuers.

The existing Community legislation was recently modernized. The two new Directives amending the initial one (Directive 85/611/EEC) should be transposed by member states by the end of August 2003. They constitute a further step in the integration of UCITS market. However, it cannot be expected a full harmonization of national legislations related to UCITS because Community legislation leaves many options to member states. The modernization did not tackle the issue of further harmonization and therefore important differences will remain. However, better understanding of UCITS Directive is envisaged through common interpretation of the text. There is flexibility to adopt implementing measures related to the definitions by the Commission after the vote of the UCITS contact committee. It is expected to extend the Lamfalussy framework to the UCITS Directive at the end of this year or beginning of next year. The ESC would replace the UCITS contact committee and CESR would provide technical advice to the Commission in the context of implementing measures for this Directive.

\subsubsection{Other prudential rules on investment in fixed income securities}

Regulation of institutional investors in Europe is based on a principle of freedom to invest, but with incentives aiming at ensuring a balanced level of financial risks. This is normally ensured via rules on investment diversifications allowing for lower capital adequacy requirements for investments in low-credit risk ("gilt edged") investment assets and rules on maximum concentration of assets ("single issuer rules"). No EU institutional investors are "captive investors" (e.g., with an obligation to do mandatory investments of a certain percent of their assets in domestic sovereign fixed income securities).

\footnotetext{
${ }^{30}$ Art. 22(4) allows for a lower risk weight for covered bonds, provided they (a) are issued by an EU credit institution, (b) which is subject to special public supervision designed to protect bond-holders, (c) investors claim on the issuer are fully secured on an ongoing basis by "eligible assets," and (d) investors claim furthermore have a priority claim on the proceeds from a subset of the issuers assets in case of default of the issuer. Presently, the Commission is considering to expand Art. 22(4) to cover also covered bonds that are not protected via a priority claim, but have a similar protection through issuance via a special purpose bank.
} 
In asset terms, banks are the most important group of financial investors in fixed income securities markets. On the securities side of banking business, the 1993 Capital Adequacy Directive (CAD) applies to investment firms as well as the trading books of universal banks. Opposite to UCITS, the CAD does not define specific thresholds for investment firms' or banks' investments in fixed income securities.

Insurance companies are the second most important group of financial investors in Europe, possessing total assets in the European Union as high as pension funds and UCITS combined. $^{31}$ EU's third life insurance directive contains investment rules that require 80 percent currency matching between the company's assets and liabilities. ${ }^{32}$

Attempts have been made to extend the single license to the management and investment of pension funds. A draft 1991 directive had to be withdrawn because of disagreements between member states on the prudential supervision. In 2000 the Commission proposed a slightly amended proposal for a directive on the activities of "institutions for occupational retirement provisions" (IORPs), which are pension funds other than social security schemes and individual schemes, e.g. company pension funds. This proposal was agreed both by Council and Parliament on 12 and 13 May 2003. The Directive suggests free choice of asset managers and custodians and provisions on own funds that will ensure a level playing field compared to life-assurance companies (whose investments are regulated under the Single Market Program for insurance companies). As regards investment rules, the Directive will allow IORPs to have relatively high levels of investments in risk-capital products. ${ }^{33}$ The proposal, however, does not suggest as detailed quantitative provisions on investments as in the UCITS directives.

\subsection{Investor protection}

Investor protection is mainly provided for in the EU Investment Services Directive, adopted in 1993 (1993 ISD). The directive establishes the conditions in which authorized investment firms and banks can provide specified services in other member states on the basis of home country authorization and supervision. Services eligible for a passport under the existing ISD include brokerage, dealing, individual portfolio management, reception and transmission of investor orders, and underwriting/placing activities. In addition, the ISD enshrines the right of direct or remote access of any authorized ISD firm to participate in trading on exchanges/regulated markets in other member states. To support the effective exercise of this right, the ISD defines some characteristics for mutually recognized exchanges and impose some conditions on the operation of those markets. The ISD is therefore the legal instrument that seeks to translate Treaty freedoms into practice in respect of investment services and organized trading of financial instruments.

\footnotetext{
${ }^{31}$ Gros, 2000.

${ }^{32}$ According to Gros, 2000, page 64, EMU has made this EU currencies matching rule irrelevant for euro area life insurance companies, allowing them to spread their assets in a larger currency area.

${ }^{33}$ Draft Article 18 of the proposal will allow member states to define investment rules for IORPs. However, an IORP shall at least be given the possibility to invest up to 70 percent of their assets in shares and corporate bonds and shall have access to invest in risk capital markets.
} 
The 1993 ISD refers to the 1993 Capital Adequacy Directive (CAD), which sets capital ratios for investment firms and for the trading book of banks. It is also supplemented by the 1996 Investor Compensation Schemes Directive that introduces a minimum level of protection for (retail) clients of investment firms and banks.

The 1993 ISD mainly regulates EU secondary equity and corporate bond markets and as a general rule - only to a limited extent provides regulation on fixed income securities that differs from that of equities. It focuses on retail investors (protection of small investors, via rules on transparency and disclosure of the price formation process) as well as of wholesale investors (rules on access).

In November 2002 the Commission adopted a suggestion for a Directive that will replace the present 1993 ISD (The 2002 ISD Proposal). The background for the proposal is a general acceptance that the 1993 ISD no longer provides an effective framework for undertaking investment business on a cross-border basis in the European Union. It does not establish clear ground-rules within which competition and consolidation of trading infrastructures (exchanges and other trading venues) can take place.

\subsubsection{Capital adequacy rules}

Under the 1993 ISD, compliance with the 1993 CAD initial and ongoing capital requirements, is a pre-condition for authorization and operation as an investment firm. These rules also aim at providing a level playing field compared to banks that are active in securities markets.

The 2002 Proposal for ISD revision envisages modification of the Capital Adequacy Directive to clarify that investment firms which provide only the service of investment advice shall be exempted from obligation under the Capital Adequacy Directive. This clarification is achieved through Art. 62 which proposes to add a $4^{\text {th }}$ indent to Article 2(2) of 93/6/EEC which clarifies that investment firms which are authorized to provide only the service of investment advice are not to be regarded as investment firms for the purposes of CAD. This special treatment of investment advisors for the purposes of the capital adequacy Directive is in addition to the existing exemption for investment firms which receive and transmit client orders without holding money or assets on their behalf.

\subsubsection{Conflicts of interests}

Investors must have confidence that brokers actively exploit new trading opportunities in order to obtain the "best deal" on client's behalf. Client interests must not be adversely affected by the existence of conflicts of interest when they rely on broker-dealers to execute their orders. Market professionals, issuers and regulators have a shared interest in ensuring that liquidity is not fragmented into shallow and disconnected pockets.

The 2002 ISD Proposal replies to these concerns with a package of measures to ensure that the dispersal of trading across multiple marketplaces and through diverse trading channels does not fragment liquidity and prevent market participants from identifying mutually 
advantageous potential trades. At the heart of this package is an effective transparency regime which seeks to ensure that appropriate information regarding the terms of recent trades and current opportunities to trade at all marketplaces, trading facilities and other trade-execution points is made available to market participants on an EU wide-basis. The proposal will also introduce enhanced obligations to ensure that intermediaries make active use of this information so as to get the best deal for their clients (see Section 4.2.4 below).

The proposed provision establishes an obligation for investment firms to, first, identify conflicts of interest that arise in their business activities that might prejudice the interests of their clients. Investment firms would then be required to either prevent those conflicts of interest from adversely affecting the interests of clients, or establish organizational and administrative arrangements which allow them to manage these conflicts of interest in such a way that the interests of clients are not adversely affected.

The provision does not prescribe the nature of organizational or administrative arrangements that shall be considered appropriate for management of different forms of conflict of interest, or way in which conflicts of interest must be disclosed where relevant. The provision foresees that detailed implementing measures be adopted at level 2 to provide guidance on these points.

Where the firm has sought to manage conflicts of interest through the establishment of organizational arrangements but it cannot be ascertained with reasonable confidence that these conflicts of interests no longer potentially prejudice the interests of clients, the firm shall disclose the existence of these residual conflicts of interest to the client. Disclosure may, where appropriate or necessary, be generic.

The proposal also recognizes that brokerage clients should be allowed to express any preference that they may have as regards the channels through which their order may be executed. Information that may be relevant to the choice of broker or perception of quality of execution-service should be provided up-front so as to allow the client to make an informed judgement. To this end, it is proposed that the retail investor should give its prior consent, either on a general or on a trade by trade basis (see draft Article 3.5), before its orders are executed elsewhere other than on a "regulated market" or Multilateral Trading Facility.

A particular concern with regard to investor protection concerns the scope for conflicts of interest within broker-dealers that may execute client orders internally against proprietary trading positions - a process widely referred to as "internalization". The integrated broker-dealer has an incentive to place the interests of its trading desks before the interests of the client. The existence of this conflict of interest raises the question of whether investors/clients can be confident that broker-dealers will comply with their over-riding duty to act in the best interests of the client. These conflicts of interest are already commonplace under the existing ISD and under those national regimes which allow broker-dealers to execute client orders outside the rules of a "regulated market." However, these conflicts of interest may be exacerbated where the investment firm has an active strategy of internalising client order flow and minimising the orders that have to be finalized on-exchange. 


\subsubsection{Conduct of business rules when providing services to clients}

Conduct of business rules are one of the mainstays of investor protection. Implementation of the 1993 ISD provision (Article 11) has been hampered by a lack of clarity as to interpretation of the main operational concepts (professional/retail investor), ambiguity as regards the role of home and host authorities in enforcing these obligations, overlap with market integrity issues, and inclusion of unworkable tests ("look through").

Therefore, the 2002 ISD Proposal suggests providing for the adoption of common conduct of business rules through comitology. It is provided that these detailed rules will differentiate in their application between investment services and between professional and retail clients who require different forms and intensity of agency protection.

\subsubsection{Best execution}

"Best execution" rules are important from a broader market efficiency perspective. The operation of an integrated financial market requires that orders to buy and sell financial instruments interact effectively, freely and instantaneously with each other on a cross-border basis. Requiring investment firms to consider trading conditions on a reasonable range of execution venues, and to route orders to the venues offering the best prices, will ensure that liquidity responds quickly to price differentials. In this way, an effective "best execution" policy helps to ensure that liquidity flows to the most efficient and competitive trade-execution venues and serves as a guarantor of overall market efficiency.

The 1993 ISD provides for an optional approach to the regulation of market structure creating a formidable stumbling-block to the emergence of an integrated and competitive trading infrastructure. Article 14(3) of the Directive allows national authorities to stipulate that retail investor orders be executed only on a "regulated market" ("concentration rule"). A number of member states have availed of this option to favor the interaction of retail investor orders on centralized public order books operated by regulated markets. Other member states have elected not to use this option and have left responsibility to the investment firm to determine how best it can secure "best execution" for its clients. This has resulted in greater diversity of orderexecution methodologies in these countries. Such fundamental divergences as to the regulation of market structure have, in turn, given rise to discrepancies between national trading conventions, rules on market operation, scope for competition between order-execution platforms, and the behavior of market participants. For example, member states which allow offexchange execution of client orders have been forced to develop more sophisticated "best execution" policies, whereas this have, to a large extent been unnecessary in member states which require concentration of retail investor orders on a "regulated market."

A related issue is that market fragmentation may undermine the representation of onexchange prices that have traditionally served as an anchor for "best execution" policies. "Best execution" rules generally provide that investment firms are considered to have discharged their duties to a client when its orders are executed on a "regulated market" or at a price equal to or better than that prevailing on the "regulated market." Widespread order-execution away from the "regulated market" could drain liquidity away from exchanges and undermine the 
representation of reference prices established on regulated markets. Under this scenario, "best execution" policies that benchmark broker performance against the price obtaining on regulated markets lose their relevance as a base-line of protection for clients. Furthermore, faced with fragmentation of trading across disconnected systems and markets, investors or their brokers may not be aware of or have access to the best available trading opportunities.

Therefore, the 2002 ISD Proposal suggests (Draft Article 19) a regulation of the "best execution" obligations of brokers/broker-dealers. The first element of the provision establishes the obligation for all investment firms acting on behalf of clients to exercise due diligence to ensure that the order is executed in the conditions that are most favorable to the client. It establishes a general benchmark against which the execution of client orders may be judged in a context where transactions in the instrument in question are potentially being concluded on a variety of marketplaces. This benchmark emphasizes, in the first instance, the best net price to the client. However, allowance is made for other factors that may influence the optimal handling of the order such as the time and size of order. These considerations may be particularly relevant for professional clients with larger orders that may require more sophisticated handling.

\subsubsection{Client order handling rules}

Rules regarding the way in which client orders are processed and executed can enhance confidence in the impartiality and quality of execution services.

The 2002 ISD Proposal (Draft Article 20) suggests a requirement that investment firms establish processes that provide for the fair and expeditious handling of client orders. Fairness and expediency for the purposes of this provision are to be understood not by reference to the quality of execution of a given client order relative to conditions in the wider marketplace ("best execution"), but relative to the handling of other client orders or proprietary transactions of the investment firm.

This requires that investors should be fully aware of different channels through which his order may be executed. Information provided up-front to the investor should allow him to make an informed judgement as to which are the potential risks and benefits attached to each of the different channels available. By default, the Directive establishes that when the investor does not express his preference his orders are to be routed to those channels, such as regulated markets or Multilateral Trading Facilities (MTFs), that do not give rise to potential concerns as regards the protection of the interests of the investor (notably conflicts of interest). To this end, the client should give its express consent before its orders are executed elsewhere other that on a "regulated market" or MTF (this is through OTC dealing or against proprietary positions/internalization). The investment firm will have the right to decide whether this prior consent will be obtained on a general (e.g., at the outset of the relationship) or on a trade-bytrade basis. This consent, when obtained on a general basis, will have to be renewed annually.

In the case of limit orders, where the client specifies conditions that prevent the prompt execution of the order, the firm shall take steps to facilitate prompt execution either by routing it to a "regulated market" or by MTF, or by disclosing the limit order to the market in some other way so as to allow other market participants the opportunity to trade at the specified terms. 


\subsubsection{Dealing with eligible counterparties}

OTC trades between financial institutions and specialized trading entities, such as commodity dealers, are generally undertaken on a principal-to-principal basis. These transactions do not involve the application of conduct of business/agency protections. However, the 1993 ISD does not clarify what obligations, if any, are owed to counterparties in the event of a transaction that does not involve provision of a "service to a client." Therefore, the 2002 ISD Proposal (Draft Article 22) suggests providing explicit treatment to this type of intercounterparty trading relationship in the ISD.

This will clarify that, in the event of a transaction involving an investment firm and an "eligible counterparty," the obligations that would be owed to a client under "conduct of business rules" do not hold. It therefore creates a safe harbor for investment firms authorized to deal with a population of "eligible counterparties" without triggering the application of agency obligations. Investment firms should simply confirm with the counterparty, at any stage prior to or during (but not after) the conclusion of the transaction, that the latter accepts to trade without the benefit of agency protections for one or more transactions. The scope of the "eligible counterparty" category is heavily informed by the corresponding definition adopted by CESR for the purposes of the counterparty regime. For purposes of ISD, eligible counterparty includes the following entities:

- Authorized credit institutions, investment firms and insurance companies;

- Member states have the option of authorising additional categories of locally domiciled entity as an eligible counterparty. ${ }^{34}$

The fact that a entity falls within the category of "eligible counterparties" is without prejudice to its right to request the investment firm to treat it as a "client" benefiting from conduct of business protections.

\subsubsection{Investor compensation schemes}

The 1997 EU Investor Compensation Directive requires member states to set up one or more investor compensation schemes. All investment firms supplying investment services must belong to such a scheme (credit institutions may be exempted provided that they already belong to a scheme which guarantees protection at least equivalent to that provided under a compensation scheme and that they fulfil certain specific conditions).

The compensation scheme operates where the competent authorities have determined that in their view an investment firm appears, for the time being, to be unable to meet its obligations arising out of investors' claims and has no early prospect of being able to do so; or a judicial

\footnotetext{
${ }^{34}$ Entities recognized as "eligible counterparties" by the national competent authority under this option will be able to trade as such with investment firms from throughout the EU. Investment firms in the same jurisdiction will not necessarily be able to presume that similar entities in other jurisdictions can also be dealt with as "eligible counterparties."
} 
authority has made a ruling which has the effect of suspending investors' ability to make claims against an investment firm.

Cover must be provided for claims arising out of an investment firm's inability to repay money owed to or belonging to investors and held on their behalf in connection with investment business; or return to investors any instruments belonging to them and held, administered or managed on their behalf in connection with investment business.

Where an investment firm is also a credit institution, the member state of origin decides which Directive should apply to money claims: the above-mentioned Directive or the one that govern deposit-guarantee schemes. No claim in respect of a single amount is eligible for compensation under both Directives.

The Directive sets a Community minimum level of compensation per investor of ECU20,000, while at the same time authorising member states to provide for a higher level of compensation if they so wish. However, certain categories of investors may be excluded by member states from the scheme's coverage or may be afforded a lower level of coverage. The arrangements for organising and financing schemes are left to the discretion of member states. There are procedures to be followed where an investment firm fails to comply with the obligations incumbent on it as a member of a scheme (penalties ranging up to exclusion). Provision is made for branches of investment firms to join compensation schemes in host member states if they so wish.

The coverage applies to the investor's aggregate claim, irrespective of the number of accounts, the currency and the location in the Community. In the case of joint investment business, claims are divided equally among investors. The compensation scheme may fix a period during which investors must submit their claims. The fact that that period has expired may not, however, be invoked by the scheme to deny cover to an investor. An investor's claim must be met within a maximum of three months of the establishment of the eligibility and the amount of the claim. Obligations are laid down regarding information that must be supplied to investors.

\subsubsection{General provisions on consumer protection}

The EC Directive on distance contracts for financial services also regulates investment services. It allows a consumer that enters a distance contract (a financial services agreement entered via electronic communication etc.) certain rights toward the provider of the contract. Thus, a consumer that invests in fixed income securities via a distance contract is granted the following privileges compared to other investors: right to reflect (written terms + a reflection period), protection against unsolicited services (which therefore will require prior consent) and a complaints procedure. $^{35}$

\footnotetext{
${ }^{35}$ The Directive also introduces a general right of withdrawal for investors. However, to avoid abuse of this right, it does not apply to investments in fixed income securities and other financial services "whose price depends on fluctuations in the financial market outside the suppliers control, which may occur during the withdrawal period" Art. 6(2).
} 


\subsection{Market integrity}

Market integrity in EU legislation is mainly addressed through two different texts: the Investment Services Directive (93/22/EEC) and the new market abuse Directive (2003/6/EC) replacing the existing insider dealing Directive. The first text deals with certain preventive measures in order to ensure market integrity through transparency of transactions. The second text is more of repressive nature because it prohibits certain wrongdoing practice such as insider dealing and market manipulation.

\subsubsection{Transparency and reporting obligations of trades}

Existing Investment Services Directive (93/22/EEC) in its Article 20 imposes reporting obligations to investment firms on all transactions carried out in financial instruments dealt in a regulated market. The obligation imposed to investment firms to report all transactions on financial instruments which are admitted to trading on a regulated market to their home competent authority covers all fixed income securities within the European Union at the exception of short term paper (cf. Art 20(1) b). The reporting obligation covers also off exchange transactions. However, member states have the possibility to limit the reporting obligation to aggregated transactions in case of fixed income securities. This information should be given to the competent authority as soon as possible and at the latest at the end of the next wording day after the transaction. The information should cover at the least the details of the names and numbers of the securities bought or sold, the dates and times of the transactions, the transactions prices and means of identifying the investment firms concerned. Information to investors is also necessary for market confidence. Therefore, Article 21 of the same Directive sets post-trade transparency obligations (price and volume) including for fixed income securities. However, the competent authorities may apply more flexible provisions for such securities. Pretrade transparency on price and quantities is not foreseen in this Directive as a mandatory provision but only an option. It is too soon to envisage what will be the new requirements in the future ISD Directive related to these issues. However, it is important to note that the draft Directive follows the new Lamfalussy approach: framework principles at the level of the Directive itself and detailed implementing measures to be adopted by the Commission according to the provisions of the 1999 comitology decision.

In November 2002, the European Commission adopted a proposal for a new Investment Services Directive in order to modernize and replace the existing one. This proposal takes into account the evolution of main fixed income securities markets into purely wholesale markets with off exchange transactions. Thus, post-trade transparency obligations (price and volume) for fixed income securities are no more envisaged. It is too soon to anticipate the outcome of the negotiation on whether or not member states will be able or not to impose equivalent obligations at national level.

\subsubsection{The new market abuse Directive (2003/6/EC)}

This Directive has been definitively adopted on 3 December 2002 and member states have to transpose it in their national legislation in a maximum delay of 18 months after its entry 
into force (20 days after its publication in the EC official journal in April 2003). It replaces the existing regime related to the prohibition of insider dealing Directive (89/592/EEC) with its modernization but it also introduces the prohibition of market manipulation covering also dissemination of false or misleading information as part of the definition of market manipulation.

Fixed income securities and money markets instruments are clearly in the scope of this Directive. No difference is made depending on the nature of the issuer (sovereign, municipalities, credit institutions or corporate), on the initial maturity of the paper (short, medium or long term), on the type of market (wholesale or not wholesale) and on the type of transactions on the secondary market (OTC, on or off exchange).

The main element that will trigger the application of the provisions included in this text is whether or not the fixed income securities and money markets instruments are admitted to trading on a regulated market as defined in the Investment Services Directive. This is the case for a large part of fixed income securities that are traditionally listed on regulated markets and declared as such by member states to the European Commission, even for eurobonds that are mainly listed on Luxembourg Stock exchange (two third of the issues). This is done mainly for prudential rules related to investments done on a collective basis (UCITS but also for insurance or bank investments). However, short-term paper is traditionally not listed on regulated markets as defined in the Investment Services Directive.

This approach clearly establishes that prohibition of market abuse on regulated markets is valid for all type of financial instruments, either of equity, non-equity or derivative nature. It is a matter of principle but it does not mean the type of market manipulation encountered on equity and debt securities markets are of similar nature. Investor protection and market integrity are also important elements for the proper functioning of fixed income securities market, even if those securities are aimed at professional investors and traded on wholesale segment of regulated markets. It is worth mentioning the exemption regime established in Article 7 of this Directive related to transactions made by entities in charge of monetary and currency policies and of management of sovereign debt. Transactions done by public bodies such as central banks and treasuries are not subject to the prohibitions of the market abuse Directive defined as market manipulations and dissemination of false or misleading information if such transactions are exclusively conducted for management of the public debt for example or monetary policy purposes. The underlying principle is that public good in this context is prevailing on market participants' interest. Moreover, this text incorporate the new ad hoc disclosure regime of price sensitive information that used to be part of the Directive 2001/34/EC on the conditions for admission to listing and on the information to be published (this obligation is described infra in paragraph 3.6.2.3). Sovereign issuers and other public bodies are also required to publish all inside information as soon as possible regardless the exemption regime of Article 7.

\subsection{Market infrastructure}

The 1993 ISD sets the basic conditions for a securities market to be recognized as a "regulated market." It has led to strong competition between financial centers as investment firms have made extensive use of their right to become remote member of a regulated market. 
European primary fixed income markets are not yet fully liberalized. Primary dealer markets do not fall within the scope of the EU Investment Service Directive, and thus there is no "European Passport" (single license) for primary dealers yet. This was identified by the Giovannini Group as one of 15 barriers for cross-border securities clearing and settlement in its 2001 report. According to the report, primary dealers still enjoy some form of protection in certain EU member states through different language and qualification requirements. Other countries, however, have already opened their markets and do not require primary dealer firms to have a physical establishment (branch, subsidiary etc) in the member state.

\subsubsection{Trading}

Historically, primary and secondary markets for fixed income securities in Europe have been over-the-counter (OTC). Often, the local stock exchange provides trading systems that also allows for trading in fixed income securities, but often not much trading occurs on these systems. To compensate for this, the regulatory framework of the stock exchange often requires certain intermediaries in the market infrastructure to report information on their OTC trading in fixed income securities to the stock exchange for quotation purposes. This is essentially provided for to establish reference rates for the secondary market and / or for regulatory (tax) purposes.

Certain fixed income markets are traded at common electronic trading platforms, with Euro-MTS ${ }^{36}$ as the most prominent example. Euro-MTS is currently ${ }^{37}$ operating as an investment firm (broker/dealer) in four jurisdictions (France, United Kingdom, Belgium and the Netherlands) and as a regulated market in Italy and Portugal.

In 1993 the ISD introduced the first elements for a common regime for national authorization and supervision of regulated markets. A "regulated market" is defined (Article 16) as: (1) a trading venue that is organized on a permanent basis (and thus functions regularly), (2) that complies with publicly approved trading rules (on reporting and transparency of trades as defined in Article 1.13), and (3) that imposes strict controls on the securities admitted to trading so as to sustain effective dealing in that instrument, are eligible for authorization as regulated markets.

A "regulated market" is required to make available information "to enable investors to assess at any time the terms of a transaction they are considering and to verify afterwards the conditions in which it has been carried out" (cf. Article 21 defining broad pre and post-trade transparency requirements). Conferral of "regulated market" status requires the market to admit any duly authorized bank or investment firm from another member states as a market participant.

\footnotetext{
${ }^{36}$ Euro-MTS provides a screen-based service for trading of benchmark euro-denominated government bonds in lot sizes of 5 mill. Euro. In contrast to most stock exchange trading platforms, it is quote-driven, mainly because of a lack of permanent liquidity, and it does not act as a central counterparty. Members of Euro-MTS are required to indicate buy and sell prices.

${ }^{37}$ FESCO (2000), The regulation of Alternative Trading Systems in Europe.
} 


\section{Box 5: The MTS System}

MTS S.p.A. is the wholesale interdealer electronic trading market for government bonds in Italy and was the first European electronic market for government bonds. It is a private company that administers the electronic trading platform Tele-matico. The company was founded in Italy in 1988, was privatized in 1997, and is today owned by around 60 major international financial institutions.

EuroMTS was launched in 1999 as an international trading platform for European benchmark government bonds (minimum outstanding volume EUR 5 billion) and is fully owned by MTS S.p.A.

There are also a large number of local/national MTS companies. These local trading platforms include MTS Amsterdam, MTS Belgium, MTS France and MTS Portugal.

MTS is an example of a dealer market with hybrid features. One the one hand, it is a quote driven, multidealer system in which major market makers are obliged to display bid / offers continuously during operating hours. On the other hand, it can be characterized as a centralized, cross-matching system as market makers' quotes are aggregated in a single order book to match best anonymous bids and offers automatically subject to non-discretionary priority rules. This unique market architecture enables MTS markets to simultaneously benefit from the strengths of two distinct systems: transparency and cost-efficiency of a central electronic cross-matching system as well as liquidity and immediacy of the quote-driven system.

MTS and/or EuroMTS provides electronic market-making in wholesale markets for government bonds in all 15 EU member states, except from United Kingdom, Sweden and Denmark and Luxembourg.

Source: World Bank (2001): "Developing Government Markets - a Handbook"

A "regulated market" benefits from the right to remote access into another member state. The directive requires member states to allow a regulated market from another member state to provide "appropriate facilities" (e.g., place trading screens and terminals on the desks of remote/overseas members) so as to allow the latter to participate fully in trading on the market (Article 15.4). Under Article 16 of the Directive, the Commission is required to publish a list of regulated markets on an annual basis.

The 1993 ISD does not address the regulatory and competitive issues that arise when exchanges start competing with each other and with new order-execution platforms. At the time of ISD adoption, competition between exchanges/trading systems was non-existent. Now, competition between different methods of trade-execution (exchanges, new trading systems, inhouse order execution by investment firms) is the principal regulatory challenge confronting EU securities regulators and supervisors. Box 6 contains a description of developments in EU financial trading since the adoption of the 1993 ISD. 


\section{Box 6: Synopsis of regulatory framework for different methods of trade-execution}

\section{New developments in EU financial trading:}

The following technology-driven trends have transformed the financial trading landscape:

1. inter-exchange competition: the era of utility-run stock exchanges, acting as a single uncontested national liquidity-point, is gone. Profit-driven exchanges are now competing directly for order flow and listings, seeking to expand activities through cross-border mergers or vertically integrating along the clearing and settlement chain;

2. competition from alternative trading systems ${ }^{38}$ : new entrants are providing alternative venues for own-account trading by institutional and professional investors. These systems are now the principal organized trading venues for bond trading. However, they account for only one percent of equity trading volumes in the EU (a much lower share of equity transactions than in U.S.); ${ }^{39}$

3. increased internal execution of client orders within investment firms: the concentration of brokerage in the hands of a diminishing number of investment firms and banks is creating a situation in which large volumes of client orders can be executed "in-house" - either by crossing one client order against another or executing against proprietary position of broker-dealers. A diminishing balance of retail investor orders that cannot be executed internally is routed to exchanges for execution. This practice is well established in jurisdictions which have not introduced a "concentration rule": in these countries, available information suggests that many large institutions are currently internalizing between 15-30 percent of client order flow.

Source: EC Commission November 2002

Therefore, the 2002 ISD Proposal seeks to establish a coherent and risk-sensitive framework for regulating the main types of order-execution arrangements currently active in the European financial marketplace. It aims to create a situation in which trading interests, regardless of the medium through which they are expressed or where they are located in the European Union, are able to interact with each other on a cross-border basis in real time, so that liquidity is fully responsive to price differentials.

Central to realization of these goals is a comprehensive set of rules requiring transparency of trading information. This regime encompasses all main categories of execution method for equities transactions - regulated markets, MTFs, and off-exchange execution by investment firms. These transparency obligations aim to allow the effective, real time, cross-border interaction of trading interests without which a single financial market cannot be said to exist. This regime will also permit competition and innovation in trade-execution, or services that include trade-execution, without jeopardizing efficient price-formation. It will do so in a manner that promotes the disclosure of as much trade information as is possible, taking account of the fact the same degree of transparency is not suitable for all business models. This transparency regime will be an important guarantor of the fairness and efficiency of EU financial markets, and

\footnotetext{
${ }^{38}$ The term "alternative trading system" (ATS) has entered into common parlance as a catch-all term for a wide range of new trading support facilities whose shared characteristics are that they are not licensed as exchanges. Some respondents to the consultation have noted that this terminology is not suitable for a legal text and does not capture the specific functionality of the entities which it is proposed to authorize as a new core service. In view of this, the term "alternative" has been replaced by "multilateral." The word "system" is replaced by "facility" to avoid confusion with a well-established bond-trading outfit.

39 J.P. Morgan, 2002.
} 
of investor access to the best deal for the size and type of trade that they are considering. It is not the only guarantor.

The 2002 proposal also envisages the introduction of a new core ISD service relating to the operation of alternative trading systems, referred to as Multilateral Trading Facilities (MTFs). This will allow entities operating such systems to be authorized as an investment firm subject to a customized regulatory regime. The recognition of MTFs as a new category of investment firm is intended to clarify the nature of this business for the purposes of EU law, and to allow for the application of a common set of customized regulatory disciplines to deal with (market-facing) risks. On this basis, MTFs will be able to make their facilities and services available to users throughout the European Union on the basis of home country authorization.

\subsubsection{Clearing and settlement}

There is no EU prudential framework (authorization, ongoing supervision and mutual recognition) for intermediaries that provide clearing and / or settlement functions for fixed income securities transactions. Thus, regulation of such functions with, e.g., registrars, common depositories, central clearing counterparties (CCPs), central securities depositories (CSDs), and certain custodian banks, is a matter for regulation at the member state level.

The 1993 ISD contains a provision that in principle allows investment firms remote access to clearing and settlement systems. The 2002 ISD proposal confines its treatment of clearing and settlement to clarification of the present rights of the investment firm and regulated market populations in terms of access to / choice of clearing and settlement facilities located in other member states (Article 32). These rights are not absolute: demonstrable prudential concerns on the part of the supervisor or commercial interests of clearing and settlement providers may prevail over the access demands of investment firms or market operators.

Most recently, the European Commission has adopted a Communication ${ }^{40}$ that considers the need for EU level actions to improve clearing and settlement in the European Union. The Communication sets out, for the first time, overall Commission policy on this subject and presents possible courses of action to improve the cross-border post-trading environment. Its overall aims are to remove barriers to the finalization of individual cross border transactions and to remove any competitive distortions that prevent market forces from delivering a more efficient infrastructure for cross border activity in Europe.

\subsection{Intermediaries}

The basic regulation of fixed income securities intermediaries is the 1993 ISD, which defines the modalities for the free provision of investment services in the European Union for investment firms (brokers). The ISD refers to the capital adequacy directive (CAD), which sets capital ratios for investment services firms as well as for the trading books of banks. Also banks (credit institutions) are entitled to provide investment services on the basis of a banking license as long as they comply with specified provisions of the ISD (e.g., conduct of business rules).

\footnotetext{
${ }^{40} \mathrm{~A}$ second communication is expected later this year, explaining in more detail which kind of action the Commission envisages to meet the aims identified in its first communication.
} 
ISD requires any entity that provides investment services as its regular occupation to be licensed and supervised as investment firms in accordance with the provisions of the Directive. ${ }^{41}$ Core investment services for which an ISD license is compulsory include reception and transmission of orders, execution of orders (brokerage), dealing, individual portfolio management and underwriting. Firms can provide a combination of core and non-core services as long as they are explicitly authorized to do so and this is specified in their license In addition, licensed investment firms may also provide a range of non-core services on a cross-border basis on the basis of their ISD license. The main non-core services include safekeeping and administration of assets (custodianship), and investment advice. Firms may be licensed at national level to provide one or more non-core services without being licensed to provide any of the core services. In such cases, the firm cannot rely on this authorization when trying to provide those non-core services in other member states. Box 7 below contains a list of the main elements of the 1993 ISD:

\section{Box 7: Basic features of regulation of investment firms in the 1993 ISD}

The ISD requires an investment firm to:

$>$ Possess initial and ongoing capital reserves in accordance with the requirements resulting from the CAD;

$>$ Have organizational requirements designed to uphold the orderly conduct of the firms operations (art. 10);

$>$ Have conduct of business rules governing the way in which it acts in its dealings with and on behalf of its clients, and when participating in the market (art. 11);

Be member of an Investor Compensation Scheme Directive (art. 12 and Dir. 97/9).

Report transactions in specified instruments conducted on/off exchange (art. 20).

The ISD entitles an investment firm to:

$>$ Freely provide investment services to clients in other member states on the basis of home country supervision, except where otherwise provided for in the provision of the Directive (e.g. Articles 11, 13);

Establish branches in other member states for the provision of investment services;

$>$ Benefit from a right of access, on a direct, indirect or remote basis, to the trading systems of exchanges / regulated markets in other member states. This right also extends to membership of clearing and settlement arrangements that are used to finalize transactions concluded on the "regulated market" in question.

${ }^{41}$ Article 2(2) of the Directive contains a negative list that excludes a number of categories of operator, which would otherwise be categorized as investment firms, from the scope of the Directive. 
In the 2002 ISD Proposal, it is proposed to expand the scope of the Directive to integrate some investor-facing activities or dealing activities that (1) are financial in character, (2) are widely offered to investors, clients, or financial market participants, (3) and/or which give rise to investor or market-facing risks which could usefully be addressed through the application of core ISD disciplines. The most notable changes are to regulate as investment service also investment advice, financial analysis, and commodity derivatives business.

The 2002 ISD Proposal also seeks to create a regulatory framework in which obligations are tailored to the specific risk-profile of different market intermediaries, and which takes account of competitive and regulatory interactions between different trading formats so as to maintain overall market efficiency. Table 1 summarizes the basic features of the suggested differentiated regulatory regime.

Table 1: Suggestion for a regulatory framework for different methods of trade execution.

\begin{tabular}{|c|c|c|c|c|c|c|}
\hline & $\begin{array}{c}\text { Market } \\
\text { integrity }\end{array}$ & $\begin{array}{c}\text { Trading } \\
\text { processes }\end{array}$ & $\begin{array}{c}\text { Conflict of } \\
\text { interest vs. } \\
\text { Client orders }\end{array}$ & $\begin{array}{c}\text { Best } \\
\text { execution }\end{array}$ & $\begin{array}{l}\text { Post-trade } \\
\text { information }\end{array}$ & $\begin{array}{l}\text { Pre-trade } \\
\text { information }\end{array}$ \\
\hline $\begin{array}{l}\text { Regulated } \\
\text { Market }\end{array}$ & $\begin{array}{l}\text { Market } \\
\text { monitoring }\end{array}$ & $\begin{array}{l}\text { Prior } \\
\text { supervisory } \\
\text { approval }\end{array}$ & $\mathrm{N} / \mathrm{A}$ & N/A & $\begin{array}{l}\text { Full reporting } \\
\text { of all trades on } \\
\text { mkt. Deferral } \\
\text { for large trades }\end{array}$ & $\begin{array}{l}\text { Depth/range } \\
\text { to be } \\
\text { specified - } \\
\text { not for large } \\
\text { illiquid } \\
\text { trades }\end{array}$ \\
\hline MTF & $\begin{array}{l}\text { Capacity to } \\
\text { detect and } \\
\text { report } \\
\text { atypical } \\
\text { trades }\end{array}$ & $\begin{array}{l}\text { Prior } \\
\text { supervisory } \\
\text { approval }\end{array}$ & $\mathrm{N} / \mathrm{A}$ & $\mathrm{N} / \mathrm{A}$ & $\begin{array}{l}\text { As for reg. } \\
\text { Market }\end{array}$ & $\begin{array}{l}\text { As per } \\
\text { regulated } \\
\text { market. }\end{array}$ \\
\hline Dealer & $\begin{array}{l}\text { Comply } \\
\text { with } \\
\text { market } \\
\text { Abuse } \\
\text { Directive }\end{array}$ & N/A & N/A & N/A & $\begin{array}{l}\text { Same as per } \\
\text { trades on Reg. } \\
\text { Market }\end{array}$ & $\begin{array}{l}\text { Quote } \\
\text { disclosure } \\
\text { for large } \\
\text { dealers }\end{array}$ \\
\hline $\begin{array}{l}\text { Broker- } \\
\text { dealer }\end{array}$ & $\begin{array}{l}\text { Comply } \\
\text { with } \\
\text { Market } \\
\text { Abuse } \\
\text { Directive }\end{array}$ & $\begin{array}{l}\text { Client order } \\
\text { handling } \\
\text { rules }\end{array}$ & $\begin{array}{l}\text { Admin and } \\
\text { organizational } \\
\text { arrangements. }\end{array}$ & $\begin{array}{l}\text { Reinforced } \\
\text { obligation }\end{array}$ & $\begin{array}{l}\text { Same as per } \\
\text { trades on Reg. } \\
\text { Market }\end{array}$ & $\begin{array}{l}\text { Client order } \\
\text { handling \& } \\
\text { quote } \\
\text { disclosure } \\
\text { for large } \\
\text { B/Ds }\end{array}$ \\
\hline Broker & $\begin{array}{l}\text { Comply } \\
\text { with } \\
\text { market } \\
\text { abuse } \\
\text { Directive }\end{array}$ & $\begin{array}{l}\text { (some) } \\
\text { client order } \\
\text { handling } \\
\text { rules }\end{array}$ & $\mathrm{N} / \mathrm{A}$ & $\begin{array}{l}\text { Reinforced } \\
\text { obligation }\end{array}$ & $\begin{array}{l}\text { Same as per } \\
\text { trades on reg. } \\
\text { market }\end{array}$ & N/A \\
\hline
\end{tabular}

Source: EC Commission November 2002 


\subsection{Issuers' obligations}

Disclosure obligations of corporate information are an important tool in EU legislation for promoting market integrity and investor protection but also for ensuring better functioning of capital markets. Minimum conditions for admission of securities to listing also contribute to these objectives and were introduced in 1979 in Community legislation. Listing particulars (in case of securities listing) and prospectus (in case of offer to the public of securities with or without listing) requirements were adopted respectively in 1980 and 1989. Financial reporting standards are set in the $4^{\text {th }}$ and $7^{\text {th }}$ company law directives on individual and consolidated accounts. Nowadays, the codified Directive 2001/34/EC on the admission of securities to official stock exchange listing and on information to be published on those securities replace four previous Directives dealings with listing conditions and disclosure obligations for issuers. This text adopted in May 2001 was not a modernising of the existing Directives but simply a legal compilation. This codified Directive covers both disclosure requirements for issuers and minimum conditions for an issuer in order to be listed on an exchange. These obligations are of minimum standards and member states are free to impose more stringent conditions if not discriminatory. The way this Directive is transposed by member states is rather heterogeneous. In some countries, all the provisions are in national legislation and imposed directly to the issuer, where in certain countries the competent authority has the ability to have its own regulation covering notably EU requirements and in others, it will be the listing rules of the exchange itself that will provide for the application of Community legislation. Moreover, an exchange has always the capacity to enter into a contract with an issuer in whom the latter agrees to comply with the other exchange's requirements.

Existing Community legislation is based on a differentiation of disclosure obligations depending on the nature of securities. It is important to note that in all existing and forthcoming securities Directives, at the exception of the market abuse one, fixed income securities may benefit from a less stringent regime compared to equity securities if a member state wishes so. Community legislation recognizes implicitly that fixed income securities benefits from a lower risk profile compared to equity securities and authorizes member states to adopt a differentiated regime adapted to those securities. However, certain member states do not make important differentiation between disclosure obligations for equity and non-equity securities (for example France and Spain).

It is also important to note that European institutions are currently moving forward "a disclosure and transparency agenda" with several legislative initiatives, part of the Financial Services Action Plan (FSAP) adopted in 1999. It covers the new regulation on the application of international accounting standards and the two proposed directives on prospectus and transparency obligations for issuers that should overhaul existing securities legislation in the area of financial reporting and disclosure obligations (cf. infra).

\subsubsection{Conditions for admission of fixed income securities to trading on a regulated market}

The particular conditions relating to the admission to official listing of fixed income securities are set out in Articles 51 to 63 of Directive (2001/34/EC). They are minimum 
conditions and of basic nature in order to be sufficiently flexible to take into account the differences in the structures of securities markets in the member states. They address notably the legal status of the debt securities to be listed, the negotiability of such securities, their form (dematerialization and bearer form) and certain liquidity aspects (listing obligation for all securities of the same rank and minimum size of the issue). For sovereign and municipalities debt, a specific regime is applying (Articles 60 to 63 of the same Directive). It covers only the freely negotiability of the securities, the obligation to list the securities after the closing of the subscription, the obligation to list all securities with same ranking and specific arrangements and warnings when the securities are in a physical form. The new proposed Investment Services Directive adopted by the European Commission in November 2002 does not intend to replace and modernize these particular conditions. However, it will create a new regime for financial instruments (all fixed income securities including short term paper) that are traded on other segments of regulated markets (not only official listing) through its envisaged Article 37 . The detailed implementing measures related to conditions for admission of such fixed income securities should be adopted at a later stage according to the new regulatory approach envisaged in the securities fields (cf. Supra).

\subsubsection{Disclosure requirements and financial reporting}

\subsubsection{EU Accounting standards}

One priority of the Financial Services Action Plan (FSAP) was the adoption of financial reporting standards applied by EU companies participating in financial markets. The objective is the achievement of a single set of global accounting standards for publicly traded companies. This will ensure the comparability of consolidated financial statements prepared by those companies, contribute to a better functioning of EU financial markets and thus accelerate completion of the internal market. Existing $7^{\text {th }}$ Company Law Directive 83/349/EEC on consolidated accounts was not sufficient to ensure enough convergence between the different member states GAAP because of its minimal harmonization approach and the various options left to national legislation. Therefore, in July 2002, a Regulation ${ }^{42}$ on application of international accounting standards was adopted with the European Parliament and the Council.

This new Regulation will apply to equity and debt securities issuers including fixed income securities corporate issuers whose securities are admitted to trading on a regulated market even if they have no shares listed. However, member states may use the transitional period for those companies. The obligation to apply the adopted international accounting standards starts from January 2007 instead of January 2005. This obligation is for the time being limited to the annual consolidated financial statements and the Regulation does not address interim financial reporting. The detailed implementing measures related to the adopted international accounting standards should be completed before the end of 2003 according to the procedure set out in Decision 1999/468/EC (Comitology procedure).

\footnotetext{
${ }^{42}$ A Regulation is directly binding upon all EU member states and shall be applied directly (see Chapter 2.1.3 - Box $3)$.
} 


\subsubsection{Prospectus Directive}

Current initial disclosure requirements in Community legislation are provided in two different legislative texts mainly for historical reasons. The particular conditions for drafting a prospectus (defined as listing particulars) when securities are to be admitted to official listing are set out in Articles 20 to 41 of Directive (2001/34/EC). The scope of this Directive is limited to corporate securities and member states are free to define their own policy for sovereign and municipalities issuers. This is also a minimum coordination Directive and member states have the possibility to impose more stringent rules. A Community schedule is provided in Annex 1 of this Directive (schedule B). It contains the different minimum information items that should be included in a prospectus for fixed income securities to be admitted on stock exchange official listing. However, the existing Directive contains many options for member states to apply different disclosure rules for certain types of issuers and securities. This is particularly true for certain fixed income securities. Member states have the possibility to define national rules less stringent than the schedule B, notably for debt securities only traded by qualified investors (Article 27 used mainly for Eurobonds), for debt securities issued in a continuous or repeated manner by credit institutions (Article 29 used notably in the context of tap issues) and guaranteed debt securities by a State (Article 34). United Kingdom, Luxembourg, France and Germany are the main users of the flexibility that authorizes to have specific rules for Eurobond markets, however they are not harmonized. Other countries (Germany, Italy, Denmark, Sweden Austria and Portugal) have transposed the Article 29 in order to have a less stringent regime for debt securities issued in a continuous or repeated manner by credit institutions. Because of these national options combined with the possibility to add national more stringent rules and due to the various interpretations developed by member states during the past 23 years, it is notorious that there is no real convergence and common practice within the EU related to the drafting of prospectuses for fixed income securities. This situation has contributed to the fragmentation of EU capital markets and clearly maintains the idea, that EU regulated markets are of national nature and not Community one.

The existing Directive 89/298/EEC on the prospectus to be published when securities are offered to the public also contains some contradictions that contribute to this fragmentation. In the absence of a Community definition of a public offer of securities, it can be said that there are 15 different approaches for private placement and public offers. This situation has not encouraged cross borders operations due to the complexity of managing several offers in different jurisdictions.

To remedy this situation, in May 2001, the European Commission adopted a proposal for a new prospectus Directive in order to replace the two existing sets of Community rules related to initial disclosure requirements. The proposed Directive seeks to ensure that adequate and equivalent disclosure standards are in place in all member states when securities are made available for all European investors either through a public offer procedure or because they are admitted to trading on a regulated market. The proposed Directive includes in its scope all types of securities normally traded in the market at the exception of sovereign and municipalities issues. There is not enough support from member states and Parliament to include municipalities in the scope of this Directive. For sovereign issues, very few member states are used to produce a set of documentation when offering government securities to the public like in the United 
States. To avoid loopholes and disparities in the treatment of retail investors, it will introduce a standard definition of a "public offer." It includes definition of clear conditions for offering securities to the public and for admission to trading with a harmonization of the essential definitions in order to avoid loopholes and different approaches, thus ensuring a level playing field throughout the EU. Exemptions of information items and derogation of prospectus are harmonized and member states have no more the possibility to apply national rules (less or more stringent rules). For investors, the proposal would ensure better quality of information through the introduction of enhanced disclosure standards based on international standards (IOSCO) for public offer of securities and admission to trading. This text also includes an automatic mutual recognition procedure for cross border offers and listings with the possibility to offer or admit securities to trading on the basis of a simple notification of the prospectus approved by the home competent authority.

The proposed Directive follows the Lamfalussy-procedure (see Chapter 2.1.2). Thus, implementation measures in several specific areas shall be adopted with the European Commission after consultation of member states' representatives in a Securities Committee. These areas are notably the specific disclosure standards for prospectuses adapted to the different nature of issuers and securities, including for fixed income securities because both Council and European Parliament felt necessary to adopt a differentiated regime for such securities. An amended proposal was adopted in August 2002 in order to take into the amendments introduced by the European Parliament and the negotiations at Council level. This text, after minor modifications, has been agreed by the Council and sent to the European Parliament for its second reading. The main changes related to fixed income securities compared with the European Commission's original proposal are the introduction of special EU rules for securities with an high minimum denomination ( $€ 50000$ ), which are designed to be traded by qualified investors (notably eurobonds), adapted schedules for non-equity securities such as bonds and the introduction of new prospectus formats for frequent issuers, notably for offering Euro Medium Term Notes or for mortgage bonds issued on a continuous or repeated basis.

\subsubsection{Periodic and ongoing disclosure requirements}

Current periodic and ongoing disclosure requirements in Community legislation are set out in Articles 64 to 97 of Directive (2001/34/EC) on the admission of securities to official stock exchange listing and on the information to be published on those securities. These articles cover periodic reporting (annual and half yearly), major holdings in the capital of an issuer, certain specific events reporting notably those related the shareholder meetings and the general principal of ad hoc disclosure of material information. There is a differentiation in disclosure requirements between issuers of fixed income securities whose shares are not listed and those with listed shares (the latter apply the more stringent conditions). They are minimum conditions and of basic nature in order to be sufficiently flexible to take into account the differences in the structures of securities markets in the member states. They address notably the interim reporting obligations (annual and half yearly reporting obligations but no quarterly reporting). In the case of fixed income securities issuers with no listed shares, the disclosure of periodic reporting is limited to annual reporting. Minimum requirements for securities holders are also provided, and for sovereign and municipalities debt, a specific regime applies (Articles 83 to 84 of the same Directive). These two articles deal with the equal treatment principle, the obligation to put in 
place all the necessary facilities for a debt securities holder in order to enable him to exercise his rights and the obligation to give equivalent information on all markets where these securities are listed. The general principal of ad hoc disclosure of material information was included in this Directive (Art 68(1) and 81(1). However, it has been repealed and modernized through the adoption of the Article 6 of the new market abuse Directive with a new obligation to publish all inside information (cf. Supra). There is no more differentiated regime between equity and nonequity issuers on this matter.

Again, the European Commission felt it was necessary to update and upgrade periodic information requirements for all type of securities issuers. Current EU law dates back some twenty years and should be modernized to take into account the introduction of the adopted international accounting standards. Several member states have already increased their requirements for the mandatory disclosure of information by issuers, largely exceeding the requirements currently imposed by EU law. In March 2003, the European Commission adopted a new proposal for a Directive on transparency obligations for issuers. The proposed Directive will apply to all companies whose fixed income securities are admitted to trading on a regulated market in the EU. It takes into account the particularities of wholesale bond markets, such as the eurobond markets, along the same lines as in the Prospectus Directive (no periodic reporting requirements envisaged for those who issue solely bonds the denomination of which is $€ 50,000$ or more).

The proposed Directive would require to disclose to the public periodically an audited annual financial report (financial statements based on international accounting standards) and a management report, within three months of the end of each financial year and a half-yearly condensed financial report based on international accounting standards on interim financial reporting (IAS-34) as well as an update of the last annual management report. In addition when an issuer of fixed income securities issuers has also its shares listed, quarterly financial information would be required. All this interim information would need to be published within 60 days after the end of the period concerned.

The proposed Directive also upgrades the current requirements on information that is not periodic notably securities issuers would have to provide information to holders of debt securities so as to facilitate participation in general meetings. This would include information about proxy voting under the law of the issuer's home member state. This proposal intends to modernize also existing Community rules on means for dissemination of information to the public and requirements on languages and has been drafted in conformity with the institutional arrangements laid down in the Stockholm European Council Resolution which resulted from the recommendations in the Lamfalussy-report (see Chapter 2.3).

Final adoption of the new prospectus Directive was reached after European Parliament's second reading on 2 July and Council's agreement on 15 July 2003.

\subsection{Taxation}

A major element of the competitiveness of fixed income securities market in Europe is related to taxation. However, there is no such equivalent incentive as the U.S. tax-exempt 
regime for sovereign and municipalities debt securities. Nowadays, there are important differences between EU member states in the taxation of interest payments coming from debt securities. Certain member states decided to encourage the development of fixed income securities market at national level by ensuring that non-residents will not bear any taxation for revenues coming from the holding of debt securities. This is one of the main elements of the success of the eurobond market (international debt securities) and any major modification of this regime could lead to negative consequences to market places such as London and Luxembourg. Some member states have also created some tax incentive at national level for fixed income securities with a more favorable regime applying for debt securities compared to equity securities. The fact that member states need to finance their deficit and therefore need to offer to investors their sovereign debt partly explains this kind of differentiated tax regime. The same reasoning is valid for the difference between taxation for residents and non-residents. Some member states have favored a system of withholding tax where some prefers to tax the income of interest payments like the other incomes. All these elements concur to a great diversity of situation and it was felt necessary by the European Institutions to adopt a common regime at EU level at least for cross-border interest payments to individuals among member states.

In June 2000, the Feira European Council reached a historic agreement on the taxation of savings and maintained momentum in the tax package, initially agreed in December 1997. It is worth noting that Community legislation in the taxation area needs unanimity at Council level. The member states agreed to information exchange as the ultimate objective of the EU's tax policy. An interest payment made in one member state to an individual resident in another member state should be effectively taxed in accordance with the laws of the latter member states. This means that an EU individual resident will be taxed wherever he lives in the European Union. This system implies efficient exchange of information between member states for taxation reasons and therefore modifications of bank secrecy legislation in certain member states. A proposal for a Directive was adopted with the Commission in July 2001. The effective introduction of this Directive should limit harmful tax competition within the Community and ensure greater harmonization on taxation level of interest payments coming from fixed income securities, even if it is not an attempt to harmonize domestic tax treatment of such income. It may force certain member states to reduce their tax rates on domestic interest payments coming from fixed income securities.

The efficient lobbying of certain market participants involved in fixed income securities market is one of the reasons why this proposal is solely based on exchange of information. An alternative regime based on a withholding tax (where interest income would be taxed at source by the paying agent) was rejected because Eurobond market participants feared the negative impact of such a withholding tax on the Eurobond market. A grandfathering clause is included in the proposed Directive to avoid market disruption for already issued fixed income securities. Eurobond issuing contracts generally include gross up clauses with the effect to create a compensation obligation to investors if any tax is withheld.

However, there are still important difficulties in order to obtain a final adoption of this Directive proposed by the European Commission. This Directive should have been adopted no later than 31 December 2002 once sufficient guarantees have been obtained on the adoption of equivalent measures by certain key third countries and associated territories in order to avoid 
important movement of savings outside of the European Union. A transitional period until 2009 was granted for certain member states (Belgium, Luxembourg and Austria) that applies withholding taxation today in order to avoid important modifications to their bank secrecy regime. At the Council on 19 and 20 March 2003, all delegations but one agreed on the present draft Directive and the draft agreement with Switzerland and Liechtenstein, Andorra, Monaco and San Marino. However, unanimity is required for the final adoption of the Directive and the related agreement with certain third countries. A final agreement was reached in Luxembourg on 3 June 2003 paving way for the final adoption of this Directive.

\section{CHAPTER 4 - COUNTRY CASE: FRANCE}

This section is divided in three parts. The first part is related to the description of the French sovereign fixed income securities market. The second part describes the French private fixed income securities market (public entities, corporate and credit institutions) and the third part deals with the French regulatory and supervisory framework, notably with a description of the authorities involved in the supervision of the French debt market and its regulatory environment.

\subsection{The French government debt market}

In 1985, the French Ministry of Finance implemented a series of reforms to lay the groundwork for a harmonious, liquid, attractive and safe government securities market. The objective was to enable the state as an issuer to borrow on optimum conditions while offering market participants standardized securities and easy and safe access to the primary and secondary markets.

In order to ensure the success of this reform, the composition of government debt has been divided in three categories of standardized government securities: OATs, BTANS and BTFs. These securities are distinguished by their initial maturity on issue.

OAT - Obligations Assimilables du Trésor (fungible treasury bonds) are the government's long-term debt instruments with initial maturity from seven to 30 years, ${ }^{43}$

$>$ BTAN - Bon du Trésor à taux fixe et à intérêts annuels (negotiable fixed-rate medium-term treasury notes with annual interest) are medium-term government debt securities with an initial maturity from two to five years, ${ }^{44}$

BTF - Bon du Trésor à taux fixe et intérêts précomptés (negotiable fixed rate discount treasury bills) are the French government's cash management instrument. They are mainly use to cover short-term fluctuations in the government's cash position (maturity up to one year).

\footnotetext{
${ }^{43}$ OAT initial maturity and interest payment date are usually set on the 25th of the month (generally April or October).

${ }^{44}$ BTAN initial maturity and interest payment date are set on the 12 th of the month.
} 
For practical reasons, the individual denomination of such securities is one Euro because quotation of fixed securities is done in percentage. With the introduction of the Euro currency, it was felt necessary to introduce such a system.

In addition, the Ministry of Finance decided in 2000 to create a specific agency (Agence France Trésor), dedicated to the management of French government debt securities. This agency is seconded by a Strategic Committee in order to advise on the main lines for a government financial policy (including exchange offering, ${ }^{45}$ securities buy-backs through reverse auction ${ }^{46}$ and use of interest rate swap).

\subsubsection{Framework of the issues}

The government bond issues relied on a voluntary transparency principle with exhaustive information made available to investors.

\section{Transparency principle}

There is an annual funding program for the three types of debt securities issued by the State. Announcement of the issues is done in advance at the beginning of each period. OAT issues occur every first Thursday of the month and a BTAN auction is conducted every third Thursday of the month. Envisaged volume is published in advance for each half yearly period and for BTF auction, it occurs every Monday with information published in advance on a quarterly basis.

\section{Exhaustive information available to investors}

The Agence France Trésor publishes a monthly bulletin, an annual review and an annual report. Typically, the content of the monthly bulletin includes information relating to primary issues (with a description of the terms and conditions of the new issue(s)), information concerning the secondary market such as the average amount traded during the last month or the five most traded OAT during the past month, as well as a detailed French government debt description (amount and maturity) at the most recent date. Finally, the monthly bulletin includes a calendar of the next issues (BTF, BTAN and OAT) and an update of key figures of the French economic (with international comparison). The monthly bulletin, as well as detailed historical data and recent information, are available on the website of the Agence France Trésor.

\subsubsection{Structure of the government bond market}

\subsubsection{Figures}

The outstanding amount of French government debt as of December 31, 2002 was about 717 billion Euro with an average maturity of five years and 343 days. The following breakdown gives figures for the three different types of instrument:

\footnotetext{
${ }^{45}$ Through a paper takeover.

${ }^{46}$ An alternative form of a cash takeover.
} 
$>$ BTF : 88 billion Euro with an average maturity of 105 days,

$>$ BTAN : 151 billion Euro with an average maturity of 2 years and 96 days,

$>$ OAT: 477,7 billion Euro with an average maturity of 8 years and 53 days.

Twenty BTAN and OAT issues have an outstanding amount of more than 15 billion euros (out of 50 issues, 40 are OAT issues and 10 are BTAN issues). Due to the low rate environment, most of the issues bear a fixed interest rate (only two issues bear a TEC $^{47}$ floating rate and four bear a fixed interest rate partly linked to the inflation index).

At the end of October 2002, 35 percent of French government debt securities (266 billion Euro out of 706 billion) were held by non-residents (BTF for $21 \mathrm{bn}$, BTAN for $83 \mathrm{bn}$, and OAT for $162 \mathrm{bn}$ ), 35 percent by insurance companies and retirement funds, 15 percent by banks and about 9 percent by UCITS. Each year (since September 1994), the French Treasury reserves a small part of its OAT issue program for retail investors (especially with the launch of the inflation index linked government bond two years ago). However, this part is non-significant compared with the outstanding amount of the French government debt.

Due to the 2002 environment (weak economic growth, declining inflation, fragile equity market and corporate scandals) the French government bond market and more generally European government bond market rallied for most of the year reducing fixed cost of borrowing and took profit of the fly to quality.

Since the beginning of 2003, the French government debt outstanding amount has increased by 20 billion to reach 738 billion at the end of February 2003 (cf. Agence France Trésor's website). The French government debt is rated AAA by all rating agencies.

Since 1983, the French government bonds as well as corporate bonds are issued with a dematerialized form, ensuring a high level of security, especially for clearing and settlement operations.

Finally, the liquidity and the transparency of the French government bond market allows the existence of a reliable government bond yield curve (almost all maturity are covered), which is the basic foundation of any private bond market, as well as a mandatory step to develop an hedging market ${ }^{48}$ (based on standardized future contracts and options).

\subsubsection{Primary market}

\section{Method of issue}

The principal method of issuing French government securities since 1985 has been the "bid price system" (referred to in France as "à la hollandaise"). Bank syndication is used only in special circumstances.

\footnotetext{
47 Taux à Echéance Constante: index of long-term government bond yield.

48 The "fixed income" futures and options market are supported by a pool of French and German bonds; therefore, investors in the Euro Notional contract can be sure that the underlying pool is an adequate size and depth.
} 


\section{Methodology: the bid system price}

The bid price system consists of serving securities at the bid price or the effective bid rate as opposed to the marginal price or rate. This type of auction is known as an "auction with several prices and sealed prices." The highest bids are first served, followed by lower bids and so on, up to Agency France Trésor's target amount. Participants pay different prices, precisely reflecting their bids.

However, on $3^{\text {rd }}$ October 2002, the French Minister of Finance mandated four SVTs for placing a new issue of OAT linked to the Euro area harmonized index of consumer price. This syndicated issue intended to reach a broader range of investors compared to auction.

\section{Primary dealers}

Since 1987, the state's issuance policy has relied on a network of primary dealers (Spécialistes en Valeurs du Trésor: SVT ). The SVT's mission is to maintain the liquidity of both primary and secondary government debts markets. The SVT are selected for a 3-year period. ${ }^{49}$ On January 2002, the group of primary dealers comprised 7 French banks and 14 foreign institutions (6 U.S., 3 Germans, 2 British, 1 Italian, 1 Dutch and 1 Swiss).

At the beginning of 2003 a new charter has been established between the French Treasury and the SVT in order to improve the debt government issues. According to the charter, SVTs are responsible for placing the French government debt securities and for maintaining a liquid secondary market. In particular they have to meet the following obligations:

$>$ To help ensure the success of the auctions (they are required to participate significantly in all auctions (even if they don't have the monopoly on auctions) as well as to estimate the demand of the market)

$>$ To maintain a perfectly liquid secondary market in government debt securities by displaying permanently bid and offer prices on the main issues

$>$ To make and ensure the liquidity of the repo market (which is essential for the liquidity of the debt market)

To promote investment in French government securities and inform the French Treasury securities agency on market development.

\footnotetext{
${ }^{49}$ SVTs must also comply with a number of organizational rules; such as having a permanent establishment in Paris, which trades in French government securities on behalf of the corporate groups to which they belong. Such entities must also have trading, sales and economic and strategic research teams in Paris, and the required technical, logistics and financial facilities (back-office and middle-office). Lastly, they have to comply with some business ethic rules, laid down in 1997 in a code of fair practice by Association des Spécialistes en Valeurs du Trésor, the association of French primary dealers.
} 


\subsubsection{Secondary trading}

Lastly in July 1999, the SVTs launched plans for new electronic trading platform for French government debt securities, MTS France, ${ }^{50}$ developed in partnership with Euronext Paris (Paris stock exchange) and MTS Spa. This platform started operating in the second quarter of 2000. In 2002, the French government debt was mainly transacted on this platform as well as on the EuroMTS platform where the main European government debt issue ${ }^{51}$ are traded (less than 1 percent was traded on Euronext Paris). All OAT are listed on Euronext Paris, however the effective dealing market is MTS. There are two main explanations: the OAT market is essentially a professional market and only credit institutions are allowed to trade on the MTS market. (Therefore the market is not perturbed by retail or institutional investors. Order and bid/offer prices can be made for a standardized size, generally 10 or 50 million Euro).

The French government debt market liquidity is also the consequence of a well-developed repo, strip market and settlement/delivery procedures.

\section{The strip}

A strip OAT consists of, in exchange of a bond, requesting separately tradable securities each representing an interest maturity and a capital maturity (known as the principal). A strip operation can be reversed at any time assembling all of these distinct stripped securities (Euroclear France ensures the security of stripping and reconstituting operations). This possibility, first made in 1991, has attracted many investors who want to have a greater exposure to interest rate movements (a stripped bond has a greater sensitivity to interest rate fluctuation) or due to the elimination of the interest rate risk of reinvestment each year, who want to match perfectly the duration (technically speaking the duration is the same as the maturity of a stripped bond) of their portfolio with their liabilities (stripped bonds are very practical tool for assets and liabilities managers). On January 1, 2002 outstanding OAT strips came to about 35 billion Euro compared with 15 billion in Spain and less than 5 billion in Germany.

\section{The repo market}

The repo market is an important link between long and short-term debt markets. A repo is a repurchase agreement between a seller and a buyer, whereby the seller agrees to repurchase and the buyer to re-sell the securities at an agreed price and at a stated time. In addition to the irrevocable commitment by both parties, delivered securities repo transactions involve exchanges of cash and of securities at the beginning and at the end of the transaction. These transactions are made through the parties' Banque de France account which ensures a high level of security. An act of December 31, 1993 gave a legal status to the repo market. However no implementing measures is accompanying this act. The repo market (the French government repo market is the

\footnotetext{
${ }^{50}$ Nevertheless a number of euro-denominated non-sovereign securities are also listed, namely three CADES (Caisse d'Amortissement de la Dette Sociale) securities, one ERAP, and two CRH (Caisse de Refinancement de l'Habitat) securities with maturities ranging from 2 to 11 years.

${ }^{51}$ In order to be traded on EuroMTS government bond must meet two main criteria: Principal amount outstanding of not less than euro five billion and not less than eight European Primary Dealers or Single Market Specialists agreeing to accept market making obligations in respect of the financial instruments issued by such issuer.
} 
second most liquid repo market after the U.S.) has improved the fluidity of the bond by allowing investors to be able to price without having the concerned bond in their portfolios and funds to generate safely interests for short periods. As a result, the French Treasury has created a new category of market maker to manage the repo market. However, the primary dealers (SVTs) are also the repo market makers. The Banque de France publishes daily benchmark rates for each maturity, based on the prices quoted by SVT, and has no other particular supervisory or regulatory role. This enables investors to know at all times what are the market conditions. Finally, the efficiency of this market relies on efficient clearing and settlement procedures which are organized by the Banque de France and Euroclear France.

\section{The delivery and settlement procedures}

Government securities transactions are settled through Relit Grand Vitesse $(\mathrm{RGV})^{52}$ developed by Euroclear France in partnership with the Banque de France. Euroclear France also acts as a central securities depository for government debt securities. RGV participants are financial intermediaries, issuers and foreign depositories and international clearing organizations. The Banque de France is a key player: it acts as a payment agent, as a counterpart for intraday repo and it initiates transactions on the money market. This network ensures a high level of security and confidence on the French debt market.

Finally, development of the French government debt, as well as of the private debt market has been favored by two historical measures:

- An attractive taxation regime for individual residents with a 26 percent inclusive taxation rate $^{53}$ (instead of being linked to the level of the investor income tax rate, as it is for the share taxation)

- A well developed and organized demand, especially through UCITS (the outstanding amount managed by French UCITS. ${ }^{54}$

\subsection{The private debt market}

\subsubsection{The short-term debt market}

Besides bonds, another type of fixed income debt instrument being traded in the French domestic market is Titre de Créances Négociables (TCN). They are governed by French law and are not defined as securities under French Law, rather as money market instruments because they are not aimed at being listed in the securities regulated markets and are not offered to retail investors. This kind of short-term paper would be considered as securities in most other jurisdictions because they have all the characteristics of securities (treasury bills (cf. supra), certificates of deposit, commercial paper) with the exception that they are not listed on a regulated market (it is technically possible to list such short term paper on a regulated market but

\footnotetext{
52 Transactions can be settled the same day or during a period between $\mathrm{D}$ and $\mathrm{D}+100$, at the discretion of participants. Nevertheless, the most popular period is $\mathrm{D}+3$.

${ }_{53}$ Actually an investor has the possibility to choose between a 26 percent inclusive taxation rate or its income tax rate.

${ }^{54}$ The UCITS development has been strongly favored by an attractive taxation.
} 
useless in practice). Therefore, it seems important to present the French short-term debt market because TCNs are nowadays the main competitor of the Euro Commercial Paper (ECP).

\section{History and origin}

The TCN market was created in 1985 at the initiative of French Treasury during the reorganization of the French capital markets. Prior to that date, only interbank market limited to credit institutions existed. One of the purposes of this reorganization was to enable the creation of a short-term domestic financing market open to credit institutions and also to commercial companies. Several amendments were subsequently made to the TCN regime, mainly in order to allow the issuance of very short term securities (TCN can be issued for one day) and to broaden the list of eligible issuers.

There are three main categories of TCNs:

$>$ Certificats de Dépôts: Certificates of Deposit issued by banks with initial maturity of up to one year;

$>$ Billet de Trésorerie: Commercial Paper issued by corporate issuers with initial maturity of up to one year;

$>$ Bon à Moyen Terme Négociables: negotiable medium-term notes by both corporate and banks with initial maturity exceeding one year (medium-term paper).

\section{Figures}

The TCN market has increased sharply in size over the past seven years. At the end of February 2003, there are 577 programs of TCNs (an issuer can have at the same time a certificate of deposit program and a medium-term note program). The outstanding amount of TCNs at the end of 2002 exceeded 313 billion Euro (the certificate of deposit issues represented 185 billion euros, the Billet de Trésorerie (commercial paper) issues represented 74 billion Euro and BMTN issues represented 54 billion euros). Ninety-nine percent of the issues were denominated in Euro (source Banque de France).

The minimum individual denomination is 250,000 Euro. Therefore, the TCN market is essentially a wholesale market ${ }^{55}$ (even if final owners are most of the time retail investors through UCITS). Investors are essentially credit institutions (which own 75 percent of the BT and BMTN issues), collective investments schemes, insurance companies and corporate issuers (which own 30 percent of the CD issues usually in order to manage their short-term treasuries).

At the end of February 2003, the average maturity of the BT is between one and six months while the average maturity of the $\mathrm{CD}$ is slightly higher, between three and six months. The average maturity of the BMTN is around seven years.

\footnotetext{
${ }^{55}$ However, retail investors can purchase CDs.
} 
The remuneration of a TCN is generally based on a fixed or a floating rate, however, since a few years ago new types of remuneration have appeared, such as, remunerations linked to an index (especially for BMTN issues) or a credit derivative (for CD issues).

TCNs are not listed on a regulated market. ${ }^{56}$ However the Banque de France has organized an unofficial listed market to value TCNs mainly for BMTNs because of their longer initial maturity (however there are almost no transaction on the TCNs due to the short maturity of issues and illiquidity of the market). The TCN market is not a Community regulated market within the meaning of the Investments Services Directive (93/22/EC). It has to be understood as a market regulated under French law with no direct application of the provisions related to regulated markets coming from this Directive. However, this TCN market in under formal regulatory oversight of the Banque de France.

\subsubsection{The bond market}

\subsubsection{The retail bond market}

Less than 5 percent of the outstanding French public and private bond issues are owned by retail investors.

For many investors, it is more convenient and less expensive to invest on the bond market through a UCIT (collective investment scheme) rather than to directly buy a bond on the stock exchange.

Until recently, the bond market was less attractive than the share market. Even if this is no longer true, due to the current low rate environment the bond market is not appealing (many analysts consider that the European interest rates have almost reached a bottom). Corporate issuers are not willing to sell bonds to retail investors, to the extent that it is easier and faster to deal with a banking syndicate rather than with retail investors. French credit institutions are not refinancing themselves through extensive bond issues.

However, the banking sector still continues to sell its own bonds to retail investors through its network. There are two advantages:

- A bank can make its own funding at lower costs (sometimes close to the government bond yield) irrespective of its rating (retail investors are not really aware of the meaning of the rating). Actually, there is a clear difficulty to understand information concerning the accurate level of rate of interest at the time of the issues.

- A retail investor will be more willing to keep the bond until maturity (i.e., stability).

More than three billion euros were issued in 2002 (Caisses d'Epargne (French savings and loans), Crédit Agricole and BNP-Paribas were the main issuers).

\footnotetext{
${ }^{56}$ As defined in the Investment Services Directive.
} 
Since the beginning of 2002, French banks have also started to sell structured bonds to retail investors, such as, index-like bonds or digital bonds (e.g., the coupon is function of a basket of shares, if one decreases by more than 25 percent during the year, the coupon is equal to zero). These products are in competition with insurance products or UCIT The French supervisory authority has been concerned by this type of issue, due to the market volatility and the difficulty for a non-professional investor to understand the proper functioning of these products. Therefore it requires a high level of disclosure and explanation.

\subsubsection{The "wholesale" bond market}

\section{Credit institutions}

The bank's issues represented traditionally more than 50 percent of the total bond issue. The French financial system (and the capacity to borrow) is still based on the banking system. In addition, due to the low rate environment, banks managed to issue bonds at very low conditions especially compared with their networks conditions.

\section{Corporate bonds}

The corporate bond market has increased rapidly during the past few years. Several external factors have created favorable conditions; a low interest rate environment and the introduction of the Euro and subsequently the disappearance of currency exposure which has broadened the scope of qualified investors (i.e., banks, mutual funds, insurance companies) as well as the improvement of trading and clearing conditions, but in the same time increased the competition between issuers. During the same period, issues have be driven by the increase in Merger and Acquisition activities, pressure to improve returns and shareholders value and the desire for an issuer to be less dependent on the banking system and to diversify it creditors base. Furthermore, this trend has been facilitated by banks, which have been prompted to use their balance sheets more efficiently in order to increase their return on equity.

Beyond the move to lower-grade credits is the arrival and expansion of the European high yield market, especially in 1999 with the surge in issuance by investment grade corporate bonds (Groupe André, Moulinex ${ }^{57}$ or Remy Cointreau) and in 2002 with the downgrading of many corporate issuers to an non-investment grade rating due to the weak economic growth (such as, Rhodia). ${ }^{58}$

It is worth mentioning the amazing increased volatility of spreads on the bond market especially for corporate issuers (due to the share market influence and the high level of indebtedness of many issuers). As an example, France Telecom spread on the ten-year maturity was 281 basis points at the beginning of February 2003 and 155 basis points in mid-April.

\footnotetext{
${ }^{57}$ Moulinex went to bankruptcy last year.

${ }^{58}$ A clear distinction must be made between initial junk bond issues with contingency clauses and bond issues downgraded with no contingent clauses.
} 


\section{Public entities}

The public entity issues (e.g., SNCF, EDF) have been growing quickly. This is partly due to Maastrich criteria. ${ }^{59}$ According to these criteria, the French government debt ratios must be contained in a certain level. Therefore, instead of refunding some public entities, the government has pushed them to fund themselves on the bond market. ${ }^{60}$ There is no specific regulatory framework for public entities. They are subject to the same securities regulation as corporate issuers. However, they benefit from an adaptation of the content of the prospectus to their particular nature if necessary (accounting standards, some public entities have no auditors). The French securities regulator has also established a specific schedule of prospectus for territorial communities (Schedule P).

Table 2: Figures for 2002 including tap issues (sources: dialogic and bondware)

$\begin{array}{lrrr} & \begin{array}{c}\text { Amount. millions } \\ \text { (Euro) }\end{array} & \text { Percentage } & \text { Issues } \\ \text { Central government } & \mathbf{9 1 , 2 7 6} & \mathbf{4 7 . 3 8} & \mathbf{4 1} \\ \text { Central government } & 91,276 & 47.38 & 41 \\ \text { Corp/Util (public and private) } & \mathbf{3 1 , 9 5 3} & \mathbf{1 6 . 5 9} & \mathbf{1 3 1} \\ \text { public entities } & 8,639 & 4.48 & 35 \\ \text { Public corporate } & 4,677 & 2.43 & 11 \\ \text { Public utility } & 3,962 & 2.06 & 24 \\ \text { privates } \text { entities } & 23,314 & 12.10 & 96 \\ \text { Private corporate } & 18,622 & 9.67 & 83 \\ \text { Private utility } & 4,692 & 2.44 & 13 \\ \text { Banks/Finance } & \mathbf{5 9 , 2 5 7} & \mathbf{3 0 . 7 6} & \mathbf{4 6 0} \\ \text { Private bank } & 37,131 & 19.27 & 343 \\ \text { Private finance (other) } & 7,901 & 4.10 & 27 \\ \quad \text { Finance vehicle (private } & 1,000 & 0.52 & 1 \\ \quad \text { bank/finance) } & & & \\ \text { Public bank } & 7,722 & 4.01 & 71 \\ \text { Public finance (other) } & 5,504 & 2.86 & 18 \\ \text { Authorities } & \mathbf{7 0} & \mathbf{0 . 0 4} & \mathbf{2} \\ \text { Local authority } & 70 & 0.04 & 2 \\ \text { Others } & \mathbf{1 0 , 0 9 5} & \mathbf{5 . 2 4} & \mathbf{5 2} \\ \text { Supranational institution } & 3,319 & 1.72 & 22 \\ \text { SPV } & 6,776 & 3.52 & 30 \\ \text { Total } & \mathbf{1 9 2 , 6 5 2} & \mathbf{1 0 0 . 0 0} & \mathbf{6 8 6}\end{array}$

\section{Mortgage bonds development}

Until 1999, the mortgage bond market was a "niche" with a unique issuer since 1995, the Credit Foncier de France. The French government decided to create a new type of issuer: les sociétés de crédit foncier (SCF) as an alternative to Pfandbriefe. SCF are credit institutions supervised by the French Banking Commission. Their financial statements must be certified by regular auditors and an independent specific auditor in charge of controlling the compliance of

\footnotetext{
${ }^{59}$ Established in order to "harmonize" European economics for the purpose of the introduction of euro in 1999.

${ }^{60}$ Due to their top ratings, some public entities issues can be considered as a benchmark for private issuers.
} 
the SCF assets with legal requirements (ALM). ${ }^{61}$ The minimum capital requirement is 15 million euro. $^{62}$ The sole objects of a SCF are:

- To grant or acquire secured loans and loans to public entities (government and public sector borrowers). These loans ${ }^{63}$ must meet strict requirements (described in the law) concerning the quality of the loan (loans may be secured by a first-tier rank mortgage ${ }^{64}$ hypothèque de premier rang) or a link over real property, a bank guarantee or a guarantee given by an insurance company to a certain extent), the collateral must be located in Europe ${ }^{65}$ and the risk-weighted assets which must at all times exceed the outstanding obligations foncières.

- In order to finance its assets, to issue obligations foncières. An obligation foncière is a preferred senior bond. If the issuer is subject of judicial receivership or liquidation proceedings, holders of obligations foncières have preferred claim (le privilège) on the underlying loans (even before the state or employees.) ${ }^{66}$ However a SCF can also issue unpreferred debt. The failure of the SCF's parent would not have an impact on the SCF.

There are four SCFs in France, la Compagnie du Financement Foncier (CFF), CIF euromortgage, the Credit communal d'Alsace and Dexia Municipal Agency (DMA). DMA's assets are only composed with public loans (Dexia main sector of activity is to grant loans to public entities). Until now all issues have been granted AAA by international rating agencies except for one issued by the Credit Communal d'Alsace (which was rated AA).

Practically all SCFs have been created to optimize the funding of the parent group. Therefore they are not aimed at making profits.

From September 1999 to the end of February 2003, about 45 billion Euros of obligations foncières ${ }^{67}$ (with an average maturity of seven years) have been issued by SCF (CFF for 19 billion, DMA for 21 billion, CIF euro mortgage for 4 billion and Crédit Communal d'Alsace for less than 0.2 billion).

Some bonds issued by The Compagnie du Financement Foncier (one issue) and Dexia Municipal Agency (two issues) are eligible to Euro Credit MTS. ${ }^{68}$

\footnotetext{
${ }^{61}$ The legal framework governing the activities of sociétés de crédit foncier is based on: Act $\mathrm{N}^{\mathrm{o}}$ 99-532 of June 25, 1999, Decrees $\mathrm{N}^{\circ}$ 99-710 of August 3, 1999, and No 99-1217 of December 30, 1999; Government Order $\mathrm{N}^{\circ}$ 99-10 Article 12 of July 21, 1999; Regulation $\mathrm{N}^{\circ}$ 99-11 modifying the regulation $\mathrm{N}^{\mathrm{o}} 9105$ of Comité de réglemantation bancaire et financière.

${ }^{62}$ Normally, the capital stock is reinforced by subordinated debts issued by the SCF and most of the time owned by the parent (due to their high level of remuneration).

${ }^{63}$ Units of debt mutual funds shall be treated as loans provided that their assets consist of at least 90 percent of debts of the same nature as if they were loans.

${ }^{64}$ The loan must be limited to 60 percent of the housing value.

${ }^{65}$ This requirement may be modified in 2003 to enlarge the possibilities to Canada and Japan.

${ }^{66}$ Practically, to avoid any problems with trade unions, an SCF has no employees (except the management board) and is managed by its parent.

${ }^{67}$ Sources: dialogic and bondware.

${ }^{68}$ EuroCredit MTS is a division of EuroMTS which opened for trading on May 22, 2000. EuroCredit MTS is an electronic trading platform for high quality covered bonds, such as Pfandbriefe, Obligations Foncieres and Cédulas Hipotecarias. In order to be listed on EuroCredit MTS, non-government bonds must be: collateralized with either
} 
Finally, the obligations fonciers are eligible for refinancing with the ECB and have a 10 percent risk weighted for the purpose of the capital adequacy ratio.

\section{The growing use of rating}

Portfolio managers attach more and more importance to rating (in 2002, few issues were undated).

This is becoming a form of "benchmarking" for investors and part of their internal management rules (if a company is downgraded below a certain rating, the fund manager will have to sell it), even if ratings should be considered to be supplementary information rather than a substitute for legal requirements. The sector of activity must also be taken into consideration. As an example, last year, Telecom issuers with equivalent rating as distribution issuers had to pay higher spreads.

\section{Trigger clauses}

Ratings triggers have appeared more frequently on the bond market. In essence, "ratings triggers" are contractual provisions that terminate credit availability or accelerate credit obligations in the event of specified credit actions. ${ }^{69}$ As an example a trigger clause gives lenders the right to demand the repayment of outstanding bonds once the issuer rating declined to certain levels. These triggers have been included in the contract to protect investors again any type of downgrading effects, but on the other hand these triggers could be considered as a vicious circle for the issuer (ratings triggers may contribute to the issuer's financial difficulties and escalate liquidity problems). As a result, it seems that some companies are beginning to remove rating triggers from their agreements.

\section{Exchange offer}

Since the beginning of the 1990s, exchange offers have been developed on the private bond market, due to the wish of many issuers to restructure their debt and to eliminate illiquid issues. Exchange offers are opened to the public as well as to professional investors (the bidder must prepare a document describing the terms and conditions of the offer as well as a description of the issuer and the target). There are two types of offers:

- A cash takeover: The bidder (which is almost all the time the issuer of the targeted bonds) offers to repurchase bonds at a specific price, generally higher than the market price ${ }^{70}$ and

\footnotetext{
mortgages or public sector loans, or a combination thereof; Euro denominated; in excess of $€ 3$ billion in terms of outstanding size; issued by an institution with total outstanding debt in excess of $€ 10$ billion in respect of the asset class of the bond in question (including that issue); given a triple A rating by at least one of Standard \& Poor's, Fitch IBCA or Moody's. Furthermore, in order for an issuer's eligible bonds to be selected for the system, that issuer must be selected for quoting by at least seven existing EuroCredit MTS Market Makers. As of June 2002, single-sided daily volumes averaged $€$ million with a record daily high of $€$.39 billion.

${ }^{69}$ For example, Alcatel and France Telecom have included trigger clauses in some bond contracts (especially in 2001) which state that the rate of interest paid by the issuer will be increased in case of downgrading.

${ }^{70}$ To the extent, there is an efficient market price.
} 
for a limited period of time). As an example in September 1999, the Compagnies du Financement Foncier launched a cash takeover on 14 exiting issues for a total amount of about 20 billion Euro with a successful rate of 30 percent (which is supposed to be a successful operation concerning straight bonds). Last year, Credit Agricole Indosuez, Banque Internationale du Luxembourg or Aventis did the same (Aventis launched a cash takeover on its Rhodia share linked bond with a successful rate of 95 percent).

- A paper takeover: The bidder offers to exchange existing bonds for new issued bonds. It is another way to restructure a debt, most of the time by exchanging short-term bonds again long-term issues.

The exchange offer technique is more frequently used. However, due to the market volatility (in terms of rate of interest, but also especially in terms of spread which can be substantially different from one week to another), exchange offer period has been narrowed to a minimum of five days ${ }^{71}$ (for the Aventis operation) and the price in Euro is most of the time definitively set up two days before the end of the period offered (due to the interest risk).

\section{Comparison between the government and the private bond market}

Contrary to the French government debt, private debt issues are not systematically listed on the Paris Stock Exchange (bonds may be listed or not on another exchange depending on investor's wishes. ${ }^{72}$ ) Currently, there are few transactions on the Paris Stock Exchange. The bond market is an OTC market (for the main issues, there are unofficial market makers which give an indicative quotation of some bonds on their private Reuters pages, but not on the regulated market). According to the French law an order can be traded out of the stock exchange as soon as the order is above 30,000 Euro (which is the case in 99 percent of bond transactions). A report of each transaction must be disclosed (amount and price) to the French authorities (cf. infra in 5.3.1.3). In addition, there are two intrinsic reasons for the absence of liquidity on the bond market: Bond investors do not want to make any publicity of their deals (especially when they want to sell a bond), and it is easier to trade (to reach an agreement on the price) on a oneto-one basis.

Eventually, the liquidity of most of private issues is not enough to ensure a proper repo market, even if more and more private issuers try to "tap" existing issues (e.g., to issue a bond which is assimilated to an existing issue) in order to create liquidity.

\section{A few qualitative words about the wholesale market in 2002 and perspectives for 2003}

Growth in 2002 was generally disappointing, reducing earnings and credit quality. Corporate scandals increased the corporate risk and unsettled credit markets. Corporate bond spreads widened (even if the French companies were not directly hurt by corporate scandals), particularly for lowed-rated credits on the back of these developments (and these effects were

\footnotetext{
${ }^{71}$ The maximum period accepted is three weeks. After three weeks, the French authority considers that due to the possible interest rate volatility and due to the asymmetry of information between the bidder and the bondholder, there is a risk to the bondholder.

72 Practically, many bonds of French issuers are listed on the Luxembourg Stock Exchange.
} 
exacerbated by flight to quality). The number of upgrades is dwarfed by the number of downgrades.

The corporate bond issuance volume in 2003 is expected to be similar to that seen in 2002 owing to:

- $\quad$ Reduced global mergers and acquisitions and less aggressive corporate activity

- $\quad$ Continued de-leveraging and higher equity market issuance

- $\quad$ Increased government supply expected which may have the effect of crowding out non-government supply to some extent.

However, strong technical such as continued low supply and high redemption (high redemption will in any case underpin demand) are very positive for the bond market and 2003 should be characterized (unless economic events happen) by a continuation of the trend toward a wider range of names accessing the debt markets.

\subsection{Organization and supervision of the French bond market}

In France, overall supervision of financial markets is the responsibility of the Minister of the Economy. In addition, several other bodies are charged with regulating and monitoring the markets and with overseeing financial intermediaries. However, there is no specific body in charge alone of the fixed income securities market.

Framework legislation is adopted by the French Parliament. Most of the national legislative framework are derived from the transposition of EU Directives in the securities field. However, general law empowers securities agency and central bank to take regulatory action. Detailed regulation is generally provided at the securities agency and/or central bank level. Euronext Paris (Paris Stock Exchange) has no particular role in this framework in order to avoid conflict of interest.

\subsubsection{Main French entities involved in the supervision and the regulation of fixed income securities market}

\subsubsection{The Ministry of Finance and Economy}

The Ministry of Finance and Economy prepares laws and decrees related to fixed income securities. It also approves the rules governing financial services prepared by financial regulators (the law unifies the rules applicable to all regulated markets, including fixed-income, equity, spot and futures markets). The French Treasury Agency for debt securities is the body in charge of managing the French Government bond issues and is part of the Ministry of Finance and Economy.

In addition, until 1999, through the "Comité des Emissions" (main French banks and the Treasury were involved in this committee), the Minister had the responsibility to regulate the primary bond market in order to avoid too many issues at the same time. It was especially true during the 1980s. However, since the beginning of the 1990s, due to the involvement of foreign 
banks in the French primary bond market, this Committee has been less active. The Comite des Emissions was dissolved with the introduction of Euro currency at the beginning of 2000.

\subsubsection{The French central bank: Banque de France}

Banque de France has been an integral part of the European System of Central Bank since January 1, 1999; its independence has been guaranteed by law. As a member of the ESCB, Banque de France supervises the money market and also monitors operation and protection of the French payment system.

Banque de France is also part of the regulatory framework through the Commission Bancaire (banking commission), chaired by the Governor of Banque de France and in charge with prudential control over all investment service providers other than portfolio management companies and also in charge of supervising the French banking system. Regulation is prepared under the responsibility of the Banking Regulatory Committee (CRB) and the agreement function of the credit institutions is done by the Investment Firm and Credit Institutions Committee (CECEI). These three bodies are independent authorities. However, they are closely linked with the Banque of France where the services are held by employees coming from the Banque of France.

The French Central Bank is also responsible for ensuring that all TCN issuers comply with applicable regulations. Its supervision gives the right to the Banque of France to suspend or forbid issues by an issuer who fails to comply with applicable regulations (see 5.2.1). The French Central Bank must be informed of the entry of new issuers on the market and the issuers are required to file with the BDF a copy of their information memorandum and any subsequent updates. The content of the information memorandum is defined by the French law.

\subsubsection{The Financial Market Council: Le Conseil des Marchés Financiers}

The French Financial Markets Council (CMF) was created pursuant to the Financial Activities Modernization Act of July 2, 1996, which transposes into French law the Investments Services Directive (93/22/EC). The CMF's jurisdiction in terms of regulation and supervision is not restricted solely to regulated markets. It is a self-regulatory authority entrusted with public functions by French law.

Among others things, the CMF has established general trading rules (such as "The execution of transactions on a regulated market results from the general meeting of supply and demand," best execution rules). Internalization is not possible under French law for small order trades. However, one of the most important elements is the possibility for market participants to ask that an order be executed otherwise than on the centralized regulated market if the amount of trade exceeds 30,000 Euro (derogation to the centralized order book used traditionally for equity in France). ${ }^{73}$ Due to the possibility to derogate to the "marché central," 99 percent of the debt transactions are traded off exchange (to the extent that the bond market is mainly a "wholesale" bond market and the average transaction is far above 30,000 Euro). However all transactions made out of the centralized market must be reported to the CMF (price and amount). According

\footnotetext{
${ }^{73}$ See Article 4-1-32 of CMF General Regulation
} 
to CMF's rules any transaction must be reported to the CMF as soon as possible by the investment firm. Unfortunately, because CMF's competence is of territorial nature, some transactions are not reported to the extent that transactions are made abroad with foreign entities. The CMF has no obligation to disclose this information to the public and is not disclosing these figures. All transactions are submitted to the best execution rules which apply for any investment firms. However, in the context of debt securities, due to lack of liquidity and the absence of price on the exchange itself, it is almost impossible to verify if an order has been executed at the best possible conditions. There is no obligation that OTC prices are closely linked with the quotes on the regulated market where the debt securities are listed.

Finally, the CMF lays down the compliance regulations applicable to investment services providers, market executive bodies and clearing mechanisms, securities delivery systems and central depositories. Surveillance of investment firms is done with the cooperation of the French Banking Commission (Commission Bancaire) because most of investment firms are or part of credit institutions in France. CMF has also investigation powers inside investment firms.

The CMF is also in charge of the regulation and approval of tender offers. Nevertheless, bond takeover bids are not submitted to its scrutiny.

\section{de Bourse}

\subsubsection{The French Securities and Exchange Commission: Commission des Opérations}

The Commission des Opérations de Bourse was set up by Executive Order on September 28, 1967. Laws of August 2, 1989 and July 2, 1996 provided most of its current wide-ranging powers (sanctions, international investigations, etc.). The Commission is an administrative independent regulatory and supervisory agency and is planned to be merged with the Conseil des Marchés Financiers before the end of 2003 and named Financial Market Authority.

The COB is also responsible for ensuring compliance with reporting requirements applicable to TCN issuers and that must be satisfied in the information memorandum (see 4.2.1). In addition, unrated TCN programs must obtain the approval of the $\mathrm{COB}$ for their information memorandum. ${ }^{74}$ To this end, issuers of unrated programs are required to submit their information memorandum to the $\mathrm{COB}$ at least one month before their first issue (with a copy to the BDF).

Finally, if the COB finds that an issuer (of a rated or unrated program) has not fulfilled its reporting requirements or that the information memorandum or its updates "contain errors or omissions affecting the quality of information," it is entitled to give notice to the issuer requesting it to carry out the necessary rectification. If issuers do not accede to the COB's request, the COB may terminate the validity of the COB's visa or ask the Banque de France to suspend the issues.

\footnotetext{
${ }^{74}$ The French government has appointed three rating agencies: Standard and Poor's, Moody's and Fitch Ibca.
} 
One of COB's roles is to protect investors ${ }^{75}$ against savings invested in financial instruments (including debt instrument) or in any markets based on public offering.

\subsubsection{The Stock Exchange}

The Stock Exchange (Euronext) has no particular role on the debt market. However it has established a rule book (concerning thresholds of suspension, market manipulations) approved by $\mathrm{COB}$ and $\mathrm{CMF}$ which applies to all types of securities including bonds.

In addition, the transposition of the Investment Services Directive into the French law gives to Euronext the possibility to strike out a listed security (including a bond) with the COB approval.

\subsubsection{Main areas covered by French regulation on fixed income securities market}

\subsubsection{Disclosure obligation}

\section{Approval of prospectuses}

As soon as an issuer wants to make a public offer in France (which means a public offer to retail investors or an admission to listing on a regulated market), he has to draft a prospectus. This prospectus must contain all information (terms and conditions of the notes, capital breakdown, activity, financial statements, management and forecasts, if any). ${ }^{76}$ This prospectus must be scrutinized and approved by the $\mathrm{COB}$ before the offer takes place. This document must be available to the public as well. The content of the prospectus is based on both European Directive 2001/34/EC (Annex 1, Schedule B) concerning prospectus and national company law (such as a description of environment and legal risks or some information regarding corporate governance). However, the content of a debt prospectus is less demanding than the one for equity securities. Prospectuses for equity securities issuers are more detailed in terms of description of the issuer (activity), number of years covered by the financial statements (3 years required versus 2 years) and corporate governance. The COB has established a specific schedule for municipalities and public bodies (Schema P). However, due to the national specificity of this schedule, the prospectus cannot be used for the purpose of mutual recognition. Moreover, some adaptation is accepted for certain public entities issuing fixed income securities (for instance no requirement of an auditor's opinion).

In case of private placement, no prospectus is needed. However, it is common practice to have a detailed information memorandum for professional investors. Besides, if the securities are to be listed, a prospectus will be drafted according to the COB rules. The French Government, as well as OECD states are not obliged to draft prospectuses.

\footnotetext{
${ }^{75}$ Art 1 states that "The Commission des Opérations de Bourse, an independent administrative authority, oversees the protection of savings, invested in financial instruments and all other investments offered to the public, the disclosure of information to investors and the proper functioning of financial instruments markets."

${ }^{76}$ In accordance with the COB's rule No. 2002-06.
} 


\section{Implementation of rules relating to the disclosure of corporate information}

As soon as the bond is sold to a retail investor or listed in the Paris Stock Exchange, the issuer must also comply with the obligation to disclose information related to the issuer and its securities in order to ensure the efficiency of the secondary market. ${ }^{77}$ This obligation can be divided into two types of information: the periodic information (regular reporting) and the ongoing information (events reporting but also ad hoc disclosure of price sensitive information).

The periodic information requires issuer to publish its annual financial statement at the latest six months after the end of the fiscal year. From January 1, 2005, annual and half yearly reports should be prepared according to adopted international accounting standards.

\subsubsection{Market integrity (insider dealings, market manipulations, corners, etc.)}

The aim is to detect those movements on the market:

- Which may appear abnormal when compared with the customary behavior of a given security or with that of the market overall on a given day;

- Which may be the sign of a practice contrary to the proper operation of the market or of a possible stock exchange rules breach.

In this connection, the $\mathrm{COB}$ has at its disposal, data processing resources to enable it to keep constant watch on changes in the market: computer links with the various markets to ensure comprehensive transmission in real time to the COB of all market information; analysis software enabling exhaustive and systematic tests to be carried out on all the information gathered and, where appropriate, "alarm bells" to be set off.

In any case, the $\mathrm{COB}$ can conduct investigations and decide on the action to be taken on the matter. The Chairman of the COB can order an investigation at any moment. Usually, an investigation is triggered as a result of observations arising out of market surveillance, the follow up of corporate disclosure, or as a result of complaints. The COB has investigators who are authorized: to enter all business premises; to have all documents made available to them, irrespective of the carrier and to obtain a copy of said documents; to summon and interview any person likely to be able to supply information, under the supervision of the examining magistrate; to seize documents; and to conduct on site visits in the event of investigations related to stock exchange violations. The $\mathrm{COB}$ can also for the purpose of its investigations request information from its foreign counterparts or supply them with such information. In practice, for fixed income securities, the COB will have more difficulty to detect abnormal movements to the extent that the French bond market is not a centralized market.

Following an investigation, the $\mathrm{COB}$ can impose an administrative sanction (including penalties) and/or refer the case to the disciplinary or judicial authorities for purposes of prosecution as well as to address its observations to the persons concerned.

\footnotetext{
${ }^{77}$ In accordance with the COB Rule No.2002-06 concerning the periodic information, and Rule No. 98-07 concerning the permanent obligation to disclose price sensitive information.
} 


\subsubsection{Regulation of market infrastructure (fixed income trading platforms, inter dealer} brokers, and clearing and settlement)

\section{Alternative trading systems}

The growing number of debt transaction on alternative trading systems, which are not officially recognized as regulated market has raised concerns among European regulators due to the fact that the existing regulatory framework only applies to regulated markets (as defined by the investment services directive). Some market participants think that there is no need for a regulatory framework to the extent that only credit institutions have an access to these markets and consider them as organized private markets. Some other participants think that, so long as bonds traded on these markets are also listed on a regulatory market, regulators must be concerned by the alternative trading systems (due to its impact on the regulated market). MTS France is an investment firm under French Law and not a regulated market. New securities directives (which should be implemented soon) has extended their scope of application to all transactions (notably the market abuse directive), notwithstanding if the transactions has occurred on a regulated market or not so long as the bond is at least listed in one regulated market in Europe.

\section{Inter-dealer brokers or intermediaries}

Inter-dealer brokers or intermediaries are considered by the French law as investment service providers. Therefore, they have to comply with the CMF rules. Prior to their authorization, the CMF examines the scope of the operations envisaged by investments services providers. ${ }^{78}$ The CMF assesses the applicant's organizational structure relative to the activities envisaged as well as each financial instruments and market concern. In particular, the CMF verifies that the resources to be engaged in as per the application filed are suited to the businesses planned, the integrity and expertise of its senior managers, and the suitability of their experience to their functions. Investment service providers must also comply with the CMF's rules of conduct. The core principle of the rules of conduct is that the investment services provider's activities shall be performed "diligently, honestly and fairly, respecting the primacy of customers' interests and integrity of the market" (which means, among other things, the necessity of a compliance officer, a Chinese wall). The Comité des établissements de Credit et des Entreprises d'investissement (CECEI) which is part of Banque de France is in charge of verifying the capacity and the solvency of the investment service provider in the light of its activity's program.

\section{Clearing houses}

A clearing house is a key element of the debt market infrastructure (among other things, a clearing house supervises the commitments and positions of clearing members, records the trade they are to clear, calculates and calls sum of money that the clearing members must remit to cover or guarantee their commitments or positions). Therefore, clearing houses must submit their operating rules (which include conditions for memberships, the nature and the scope of the

\footnotetext{
${ }^{78}$ See Title II and III of CMF General Regulation.
} 
guarantee that the clearing house gives to its members) to the CMF for approval. ${ }^{79}$. Clearing houses are also subject to rules of conducts (they shall perform their activities diligently, honestly and impartially). Finally, clearing houses must publish a yearly report on the conditions in which they exercise their functions (this report must include a description of how supervision and monitoring are organized and a description of the tasks performed in carrying out these duties).

\section{CHAPTER 5 - COUNTRY CASE: DENMARK}

This chapter is divided into three parts: Chapter 5.1 is an overall introduction to the Danish fixed income market and a description of the Danish Government and corporate fixed income securities market. Chapter 5.2 describes the different authorities involved in the regulation and supervision of the Danish fixed income market. Chapter 5.3 describes the main regulation of the Danish fixed income securities markets.

\subsection{The Danish fixed income market}

\subsubsection{Introduction}

The Danish fixed income market is developed around relatively proliferated mortgage bond and government bond sectors. The total outstanding volume of listed Danish Kroner (DKK) - denominated fixed income securities amounted to DKK 2,410 billion by end of 2002, equal to 176 percent of GDP. As a special feature, the outstanding volume of Danish mortgage bonds is more than twice that of government bonds. (See Table 3)

Table 3: Market value of Danish listed bonds by end 2002

\begin{tabular}{|l|r|r|r|r|r|}
\hline $\begin{array}{l}\text { Type of } \\
\text { security }\end{array}$ & $\begin{array}{l}\text { Market value } \\
\text { (DKK billion) }\end{array}$ & \multicolumn{1}{|c|}{$\begin{array}{l}\text { Market value } \\
\text { (\%) }\end{array}$} & $\begin{array}{l}\text { Turnover (DKK } \\
\text { billion) }\end{array}$ & Turnover rate & $\begin{array}{l}\text { Number of } \\
\text { bond series }\end{array}$ \\
\hline Treasury bonds & 631 & 26.2 & 2,014 & 3.2 & 42 \\
\hline Treasury bills & 63 & 2.6 & 178 & 2.8 & 4,745 \\
\hline $\begin{array}{l}\text { Mortgage credit } \\
\text { bonds }\end{array}$ & 1,426 & 59.2 & 3,349 & 2.3 & 359 \\
\hline $\begin{array}{l}\text { Special } \\
\text { institutions }\end{array}$ & 163 & 6.8 & 214 & 1.3 & 100 \\
\hline $\begin{array}{l}\text { Other (incl. } \\
\text { corporate } \\
\text { bonds) }\end{array}$ & 116 & 4.8 & 142 & 1.2 & \\
\hline Total & 2,410 & 100 & 5,899 & & 2.4 \\
\hline
\end{tabular}

Source: Danish Stock Exchange (www.xcse.dk) and Charlotte Christensen (2002): Denmark - a chapter on the bond market»

During the last three decades, fixed income markets has gained an increasingly important role in financial intermediation in Denmark, especially fostered by pension reforms in the late

\footnotetext{
${ }^{79}$ See Title IV of CMF General Regulations.
} 
1970s that has lead to increased long-term liabilities and thus increased domestic demand for long-term fixed income bonds. The organization and regulation of Danish fixed income markets has been adapted similarly. Below is a list of the main elements and operators of this development (in chronological order):

1980: The Danish Central Securities Depository, Værdipapircentralen (VP) was established for the purpose of facilitating dematerialization and settlement of listed securities. By 1983, all listed Danish bonds were dematerialized.

1988: The First Stock Exchange Reform abolished the exchange-trading monopoly with Copenhagen Stock Exchange (CSE) previously enjoyed by 27 authorized broker firms, while simultaneously substituting the trading floor with a decentralized computer trading system for bonds, equities and derivatives. Also, to protect pricing, further reporting obligations was imposed so that any member of CSE or VP was obliged to report to CSE any off-exchange trading in listed securities.

1996: The Second Stock Exchange Reform abolished the exchange-monopoly previously enjoyed by Copenhagen Stock Exchange and introduced a change in the regulatory and supervisory structure of the Danish securities market. First, responsibility for supervision of Danish securities markets was delegated to a newly established body, the Danish Securities Council while responsibility for supervision of intermediaries in the securities market remained with the Danish Financial Supervisory Authority (Danish FSA). Second, the regulatory authority was divided. From now on, Level 2 regulation of Danish securities markets was divided between the Danish Securities Council and the Danish FSA, while CSE remained to be a self-regulatory organization responsible for Level 3 regulation. The Reform also implemented the $1993 \mathrm{EC}$ directives on regulation of EU securities markets and intermediaries ${ }^{80}$ into Danish law.

To delimit the Danish market for fixed income securities, it is necessary to define what a "security" is. Danish secondary market legislation ${ }^{81}$ applies to any "security," as defined by any of the following instruments:

1) Shares and other negotiable securities equivalent to these

2) Bonds and other negotiable securities equivalent to these

\footnotetext{
${ }^{80}$ The Investment Service Directive (93/22/EEC) on the minimum authorization requirements for securities firms and on the basic conditions for a securities market to be recognized as a "regulated market," and the Capital Adequacy Directive (93/6/EEC) on minimum capital requirements for banks and investment firms (see Chapters 3.2, 3.4 and 3.5)

${ }^{81}$ The Danish 2002 Securities Trading Act, Section 2. The definition of "securities" in this Act is broader than the definition used in the Investment Service Directive (93/22/EEC). The relevant Danish securities market authority (The Danish Securities Council) is, however, entitled to exempt specified instruments from secondary market regulation. So far, such exemption has only been granted to Indskudsbeviser (Certificates of deposit) issued by the Danish Central Bank.
} 
3) Any other securities normally dealt with in giving the right to acquire such securities as listed in item 1 or 2 hereof by subscription or exchange or giving rise to a cash settlement

4) Units in collective investment undertakings and special-purpose associations

5) Money market instruments listed on a stock exchange as well as certificates of deposit and commercial papers

6) Financial future contracts and similar instruments

7) Future interest rate agreements (FRAs),

8) Interest rates, currency and equity swaps,

9) Commodity instruments, etc., including similar cash-settled instruments,

10) Options to acquire or dispose of any securities under items 1 to 9 and options for equity and bond indices, including equivalent cash-settled instruments

11) Negotiable mortgage deeds on real property or bills of sale

12) Other instruments and contracts as decided by the Danish Securities Council.

In essence, Danish fixed income market legislation applies to fixed income securities, irrespective of their initial maturity, tradability or negotiability. The legislative and supervisory framework for Danish fixed income markets, therefore, includes long-term as well as short-term fixed income instruments (government securities, mortgage bonds, other corporate bonds, listed money market instruments, certificates of deposit and commercial papers).

\subsubsection{The Danish government fixed income market}

The Danish government fixed income market can be divided in three categories of standardized government securities: Government Bonds, Treasury Note, and Treasury Bills. These securities are distinguished by their initial maturity on issue.

$>$ Government Bonds are the Danish governments long-term debt instruments. They are issued as fixed-rate bullet loans and with an initial maturity from five to ten years;

$>$ Treasury Notes are the Danish governments medium-term debt instruments. They are issued as fixed-rate bullet loans and with an initial maturity from one to two years;

Treasury Bills are cash management instruments. They are issued as zerocoupon loans and with an initial maturity of up to one year. They are presently the only listed Danish money market instrument

All tradable Danish Government fixed income securities are issued by the Kingdom of Denmark as dematerialized and negotiable securities. They are all registered with the Danish Central Securities Depository (VP) and listed with the Copenhagen Stock Exchange (CSE). 
With a single exception ${ }^{82}$, all tradable government securities are denominated in Danske Kroner (DKK) with an individual denomination of 0.01 DKK.

The Danish Government fixed income securities are traded in the secondary market along with other Danish securities and are therefore subject to secondary market regulation. ${ }^{83}$

Government securities are, however, explicitly exempt from the disclosure obligations that apply to private sector issuers, i.e, prospectus requirements (see also Chapter 5.3.1.1). This is due to the unique position of the government as a public issuer.

\subsubsection{The Danish GSE (Government Sponsored Entities) fixed income market}

The Danish Government provides guarantees for the borrowing and related financial transactions of a number of public service companies. ${ }^{84}$ A government guarantee is attractive to the borrower since it reduces borrowing costs. When a loan is guaranteed by the central government, the lender's credit risk on the loan will be reduced, so that the lender will be willing to lend at a lower interest rate.

Danish GSEs are typically structured as government-owned limited-liability companies, and their tasks are defined in an act or another legislative provision that gives access to government guarantees for loans within certain limits. The board of directors and management of each government-guaranteed entity are responsible for the entity's financial transactions, risk management, etc. The guidelines for borrowing by government-guaranteed entities are laid down in a set of agreements comprising three elements: (1) An agreement between respectively the Ministry of Finance (or the Ministry of Transport) and Danmarks Nationalbank; (2) an agreement between the Ministry and the individual entity; (3) and finally, a list of acceptable loan types.

There are no restrictions as to where GSEs can raise loans. Most of GSE funding are covered via foreign fixed income markets (mainly European). Therefore, only to a limited extent Gases issue bonds in the domestic financial infrastructure. GSE bonds registered at the Danish CSD are traded in the secondary market via Copenhagen Stock Exchange along with other Danish securities and are therefore subject to secondary market regulation. Unlike Government securities, GSE securities are not exempt from the disclosure obligations that apply to private sector issuers on prospectus requirements.

\footnotetext{
${ }^{82}$ In April 2002 the Danish government issued a euro denominated government bond with a size of EUR 1.5 billion and a maturity of five years, and a second issuance with a size of EUR 2.3 billion and a maturity of three years was initiated in May 2003. As the regulatory and supervisory framework for these bonds is similar to that of DKKdenominated bonds, it will not be further dealt with in this chapter.

${ }^{83}$ The core of Danish secondary market regulation (i.e., rules on issuance, trading, clearing and settlement of securities on a regulated market in Denmark) is held in the 2002 Act on Securities Trading, etc. ("Securities Trading $\left.A c t^{\prime \prime}\right),{ }^{83}$ as commented below in Section 5.3.1.

${ }^{84}$ Presently, the Danish GSEs are A/S Storebælt, A/S Øresund, Øresundsbron (Øresund Bridge), Hypotekbanken (the Mortgage Bank of the Kingdom of Denmark), DSB (the Danish State Railways), and Danmarks Radio (the Danish Broadcasting Corporation). As regards Øresundsbron, the Danish and the Swedish Governments jointly guarantee its debts. The borrowing, etc. of Øresundsbron is subject to guidelines laid down by Sweden and Denmark. These guidelines correspond to those for the other entities. Further information on the Danish GSE market is available in the "Danish Government Borrowing and Debt 2002," Danmarks Nationalbank (see footnote $32)$.
} 

77.8 billion. $^{85}$

Overall, the government-guaranteed debt for the entities at the close of 2002 totals DKK

\subsubsection{The Danish Mortgage backed bond market}

With a market value of DKK1.298 billion (equal to 96.5\% of Danish GDP) and a turnover of DKK 3.148 billion during 2001, the Danish mortgage bond market is the second largest in Europe (second only to the German Pfandbriefe market) and the largest in the world in per capita terms. ${ }^{86}$

The first Danish mortgage bank was set up in 1797 as a direct consequence of the need to finance the rebuilding of Copenhagen after a great fire in 1795 (see also Chapter 5.3.1.3 - Box 8). The fire resulted in the creation of a system for investment in real property with an intermediary - a private mortgage credit institution (MCI) - between investors and lenders. Since the mid-19th century, the MCIs have taken up a predominant position in the financing of real property in Denmark. ${ }^{87}$

MCIs normally offer property funding through callable bonds. These mortgage bonds usually have an initial maturity of 30 years. In recent years, MCIs have issued adjustable rate mortgage loans, which are based on non-callable mortgage bonds. These mortgage bonds have a shorter maturity and the interest rates may change over the term of the loan. The Danish mortgage credit bond market is also characterized by a very large number of series (see Table $3) .^{88}$

The market concentration is relatively high, partly due to a de facto prohibition by government for new banks to enter into the mortgage market from 1970 to 1989, when free access to the market was introduced via the adoption of a new, more liberal mortgage credit act (see Chapter 5.3.1.3-Box 8).

\footnotetext{
${ }^{85}$ In addition to the above entities, also another entity, Ørestadsselskabet, is subject to the guidelines for government-guaranteed entities. However, since the entity is a general partnership of which the central government is a co-owner no government guarantee is provided for the entity's borrowing. Ørestadsselskabet has had access to re-lending for a number of years. The extent of re-lending to the entity was DKK 9.5 billion at the end of 2002 . In 2002, A/S Storebælt and A/S Øresund gained access to borrow via re-lending. In 2002, these two government-guaranteed entities took up re-lending for a total of DKK 3.0 billion.

${ }^{86}$ Source: The Danish Mortgage Credit Association.

${ }^{87}$ Until mid-1980s, mortgage bonds were considered the Danish benchmark bonds. During the 1980s, the Danish government bond market expanded due to several years of very large public deficits. Today, with public surplus for several years and subsequently pay-back of government bonds, the situation is the opposite, and this may ultimately lead to a situation when mortgage bonds may regain their position as Danish benchmark bonds in some market segments.

${ }^{88}$ The very high number of series also gives Copenhagen Stock Exchange (CSE - the domestic stock exchange) a special function in the Danish fixed income market compared to other stock exchanges where domestic fixed income markets are often based on a few, highly liquid government bond issuances.
} 
There are rather low credit spreads between mortgage credit bonds and government bonds (usually between 15 and 45 basis points, depending on the exact duration of the bond). ${ }^{89}$ The significant dual role of the mortgage bonds as an effective funding instrument on the one hand and a secure investment on the other hand has given the bonds a central positioning the Danish capital market.

\subsubsection{The Danish short term fixed income (money) market $^{90}$}

Money markets are a core element in monetary policy operations and thus a responsibility of monetary authorities (in Denmark: Danmarks Nationalbank). On the other hand, an active money market is also a prerequisite for medium-and long-term fixed income market development (as it increases the liquidity of the longer-term securities). Money market regulation is thus at a borderline between monetary policy, securities market regulation and probably also to the banking regulation (liquidity requirements with banks and other credit institutions).

Danish securities market legislation has defined this borderline (see Chapter 5.1.1), and thus securities market legislation also applies to listed money market instruments as well as to (listed and non-listed) certificates of deposit.

Bonds with a short initial maturity (or a short remaining term to maturity) are often traded on money market terms and may be included in the group of money market instruments. This group of bonds includes commercial papers (CPs), e.g., short-term mortgage-credit bonds issued to finance adjustable-rate mortgages, and Treasury bills (see section 5.1.1).

Presently, treasury bills are the only listed Danish money market instrument. Danish CPs are short-term corporate bonds with maturities of up to one year. They are typically used for short-term financing. Aside from short-term mortgage credit bonds, CP programs are only used by very large corporations, which have high ratings. ${ }^{91}$ They are short-term securities and, consequently, they are traded in the primary market, i.e., a secondary market for CPs is virtually non-existent. Therefore, CPs are rarely listed.

In regard to certificates of deposit, presently the only Danish issuance is Indskudsbeviser (Certificates of deposit issued by the Danish Central Bank). The relevant Danish securities market authority (The Danish Securities Council) has exempted Indskudsbeviser from Danish secondary market regulation.

\subsubsection{Other Danish fixed income markets}

For various reasons (size of the economy, certain specialized institutions and a very strong banking and mortgage credit finance alternative), the Danish fixed income market outside

\footnotetext{
${ }^{89}$ The rating of the five largest MCIs range from Aaa to Aa2. For further information, see the homepage of the Danish Mortgage Credit Association.

${ }^{90}$ For further information, see The Danish Central Bank, Monetary Review 2Q2002 "The Danish Money Market."

${ }^{91}$ As they are short-term bonds, the credit risk assessment is based on Standard \& Poor's and Moody's ratings for short-term debt.
} 
the government bond and the mortgage credit bond market is negligible. Below is an overview of the main elements of these markets.

\section{Municipal bonds}

Danish local governments are based on a constitutional right ${ }^{92}$ for citizens to handle a number of local and regional tasks through their own representatives. Danish local governments are legal entities constituted by Acts of Parliament. The local government system presently consists of 271 kommuner (municipalities) and 13 amter (counties).

Municipal bonds are not issued directly by local authorities, but via KommuneKredit, a specialized, non-profit Danish mortgage credit institution. ${ }^{93}$ KommuneKredits benefits from a very high asset quality. ${ }^{94}$ KommuneKredit can only lend to local governments in Denmark or entities guaranteed directly or indirectly by local governments in Denmark. The financing of local governments is restricted to financing capital expenditure, not current expenditure or commercial projects. Furthermore, the local governments are subject to strict regulations, controls and supervision by the central government. Local governments are empowered freely to levy taxes on personal income and have an obligation to levy sufficient taxes to balance their annual budgets. Furthermore, an equalization system has been established, which enables also local governments with a lower income base to provide adequate services.

There are no restrictions as to where local governments can raise loans. Most of Kommunekredits funding is covered via foreign fixed income markets (mainly via European and Japanese markets). Therefore, only to a limited extent KommuneKredit issues bonds in the domestic financial infrastructure. Bonds listed on the Copenhagen Stock Exchange divide fairly between annuity loans and index-linked ${ }^{95}$ loans.

\footnotetext{
${ }^{92}$ Section 82 of the Danish Constitution reads as follows: "The right of the municipalities to manage their own affairs independently under the supervision of the State shall be Laid down by Statute."

${ }^{93}$ KommuneKredit was established in 1898 by Act to provide cheap financing to the Danish local government sector. Presently, it provides for 60 percent of all Danish local government financing (the rest is provided by banks and MCIs). KommuneKredit is organized as an association, whose members have joint and several liability for all of its obligations and is supervised by the Danish Ministry for Internal Matters. Members are not permitted to withdraw from the association while any loan made to or guaranteed by them remains outstanding. All municipalities and counties in Denmark are members of KommuneKredit. All of KommuneKredit's funding has to match the terms and conditions of the lending to local authorities. Derivatives might be used to create a certain currency or amortization profile. Due to this matching criteria KommuneKredit was excluded from certain markets for cheap funding. To avoid this situation, the Ministry for the Interior has decided to allow KommuneKredit to raise up to DKR $1.5 \mathrm{bn}$ without necessarily having a commitment from a local authority to take the funding. The funds raised on this basis must be invested in the same currency and in highly liquid and highly rated bonds. In respect of the use of derivatives, KommuneKredit has clear guidelines stating required credit quality of counterparties and maximum individual exposure. All derivatives are monitored regularly. Even the proceeds from the prefunding limit of DKK 1.5 billion are fully hedged in order to eliminate any kind of interest rate and currency exposure. KommuneKredit funds are placed on deposits in banks or invested in securities typically Danish mortgage and government bonds. KommuneKredit has been assigned a zero percent risk weight by the Danish FSA.

${ }^{94}$ Danish local governments cannot go bankrupt and no financial institution has ever lost money from lending to a local authority. Due to the joint and several liability, ample reserves and the high asset quality, KommuneKredit has been assigned AAA rating by Standard \& Poor's and Aaa rating by Moody's Investor Service.

${ }^{95}$ For tax reasons, these index-linked loans are only relevant for Danish institutional investors
} 


\section{Corporate bonds ${ }^{96}$}

Domestic corporate bond market activity is low in Denmark. This is mainly due to the relatively large number of small-and medium-sized enterprises (SMEs) in Danish industry and the fact that most short-and medium-term mortgage financing of SMEs are provided with MCIs (see Chapter 5.1.4), particularly through the specialized institution - the FIH (Finance for Danish Industry $\mathrm{A} / \mathrm{S}) .{ }^{97}$

An important difference between corporate bonds and government and mortgage bonds is the credit risk ${ }^{98}$ involved. Companies, which plan on issuing corporate bonds, often get a credit rating -- the higher the credit rating, ${ }^{99}$ the higher prices the company can expect for its bonds, which will reduce the interest rate on the loan. Therefore, another reason for the low activity relates to the costs of rating.

Also, another important difference is the higher level of liquidity risk that is often involved in investments in corporate bonds, as most corporate bonds are issued in relatively small series and are often sold as private placements, i.e., the bonds are initially distributed to investors who wish to hold the bonds until maturity. Thus, secondary markets may turn out to be rather modest. Therefore, investors who wish to sell such corporate bonds on the secondary market may have to accept a reduction in the price, i.e., pay a liquidity premium in order to sell their bonds.

Exchange-traded corporate bonds have only existed in Denmark over the past few decades and equal just two percent of the total Danish fixed income market. Of these bonds issuance, $42 \%$ are issued by GSEs (see Chapter 5.1 .3 ), $35 \%$ relate to foreign and supranational ${ }^{100}$ loans issued in Denmark and denominated in DKK, and 19\% to subordinated debt issued by banks and mortgage credit institutions ${ }^{101}$.

\footnotetext{
${ }^{96}$ Sources: Danish Stock Exchange and "The European Bond Markets - An overview and Analysis for Issuers and Investors" (1997).

${ }^{97} \mathrm{FIH}$ was established in 1958 with the purpose of providing medium- and long term capital for Danish industries. It was established on the initiative of the Danish Central Bank, domestic banks, insurance companies and industry confederations. Its first domestic bond issue (maturity eight years) was in 1961. It was first rated (by Moody's) in 1989. In 1999 the majority of shares in FIH was taken over by a Swedish banking group.

${ }^{98}$ Credit risk indicates the likelihood of an investor losing part or at worst the entire principal amount, if the company that has issued the corporate bond defaults. The credit risks may vary; bonds issued by governments and GSEs are typically considered to be credit-risk free. Also, bonds issued by supranationals are usually associated with a moderate credit risk.

${ }^{99}$ The most commonly used rating firms in Denmark are Standard and Poor's, Moody's and Fitch/IBCA. Any reference in this report to Investment Grade bonds is a reference to bonds with a rating from one of these rating firms at AAA (Aaa) to BBB (Baa). Reference to high-yield or junk bonds is a reference to bonds with a $\mathrm{BB}(\mathrm{Ba})$ credit quality or lower, i.e., they have speculative characteristics.

${ }^{100}$ Supranationals typically are international organizations and institutions backed by one or more countries, e.g., the Nordic Investment Bank (NIB), the European Investment Bank (EIB) and the World Bank (IBRD). Moreover, a number of foreign companies have issued bonds denominated in Danish kroner, e.g., Statoil, Landesbank Kiel and Banca di Roma.

${ }^{101}$ Issuers of subordinated debt in Denmark exclusively include credit institutions, i.e., primarily banks and a few mortgage banks. Subordinated loans are issued as an alternative to equity in order to fulfil their own fund requirements as set out in the EU Capital Adequacy Directive (see Chapter 3.2.1). Unlike the other bond loans, bonds issued as subordinated loan capital rank lower in the order of priority if the issuer should go into insolvent
} 
Almost all Danish exchange-traded corporate bonds are issued as bullet loans, i.e, the entire principal falls due at maturity. Payment of interest typically takes place once a year and the size of such payment depends on the coupon. However, the terms of interest and repayment may vary. Some bonds carry a floating coupon rate, while others are callable (typically 3 years before maturity). Moreover, there are a few corporate bonds denominated in foreign currencies.

In regard to unlisted corporate bonds, and unlike other countries such as the United States and Germany where many and huge asset-backed securities are often listed on a stock exchange, so far, Danish banks have chosen not to securitize their loans in the form of asset-backed securities. ${ }^{102}$ Commercial papers (CPs) are commented in Chapter 5.1.5.

\section{Fixed income derivatives}

Trading in interest rate futures and options was possible in the organized market in the period from 1988 to 2001, when trading in listed Danish fixed income derivatives was moved outside Denmark. Thus, trading in Danish fixed income securities is now restricted to OTC trading (which has taken place since the early eighties).

\subsection{Key regulators and their responsibilities}

\subsubsection{Ministry of Economy and Business Affairs and Ministry of Finance}

The Minister of Finance is authorized by the Danish Parliament to raise loans on behalf of the central government. The Minister of Finance thus holds the overall and political responsibility for central-government borrowing and debt. This division of work towards the Danish Debt Office (see below) is set out in an agreement between the Ministry of Finance and Danmarks Nationalbank.

The Ministry of Economy and Business Affairs prepares laws related to Danish securities market legislation. It coordinates the political level of the legislative process, while all other aspects of this process is delegated to the Danish Financial Supervisory Authority (see below), which is a sub-government administration under the Ministry.

\subsubsection{The Danish Central Bank and the Danish Debt Office}

The Danish Central Bank is the domestic monetary policy authority. It is an independent institution under the Danish Central Banking Act and is responsible for maintaining a safe monetary system, as well as facilitating and controlling monetary flows. The Central Bank meets the requirements of the Maastricht Treaty with regard to independence (all EU central banks must be independent in taking monetary policy measures). It has been an integral part of the European System of Central Bank since January 1, 1999, but as Denmark has decided not to

liquidation. Subordinated loan capital is seen as a sort of shareholders' debt and, consequently, it is ranked after the ordinary bond loans, which are equated with creditors. All things being equal, the credit risk associated with bonds issued as subordinated loan capital is higher than that associated with other bond loans.

${ }^{102}$ Asset-backed securities do not include mortgage bonds. 
adopt the euro, it does not participate in the Eurosystem (See Chapter 2.3.3 - Box 4) in tasks related to monetary policy, e.g., its surveillance of euro money markets.

The Danish Central Bank acts as a settlement bank and overseer of Danish payment and securities settlement systems. It has no supervisory or regulatory functions towards securities markets or any of its intermediaries. It is represented in the Danish Securities Council and in the board of the Danish CSD.

Since 1991, the Danish Central Bank has undertaken the management of the centralgovernment debt through a separate in-house entity (the Danish Debt Office). As the Danish Central Bank is monetary authority as well as manager of the Government's Treasury Bill issuance, there could potentially be a conflict between monetary policy and securities market policy. However, as it does not use add-ons to Treasury Bills auctions as a monetary policy instrument, this specific conflict is not relevant.

\subsubsection{The Securities Council and the Danish Financial Supervisory Authority}

The Danish fixed income securities market is organized as an integrated system consisting of the Copenhagen Stock Exchange, the Danish Securities Center and the FUTOP (Derivatives) Clearing Center. The Danish Financial Supervisory Authority (Danish FSA) supervises all three institutions. Apart from banks, the Danish FSA supervises mortgage credit institutions, insurance companies, pension funds, mutual funds and the securities market, including stock exchanges, authorized marketplaces and securities centers, etc. Thus, in essence the Danish FSA is a single-entity supervisor responsible for supervision of all Danish financial institutions and markets. Its different tasks are reflected in its internal organization. The Danish FSA has the status of a directorate under the Ministry of Economy and Business Affairs, which has overall responsibility for legislative acts.

The Securities Market Council (Fondsrådet) was set up in December 1995 to ensure a well-functioning Danish securities market that is attractive to issuers, investors and securities dealers. The basic idea of setting up a Securities Market Council to supplement the work of the DSFA was to ensure that that the regulation of the securities markets would be able to follow market developments as well as comply with international standards. Therefore, its members represent issuers, investors, traders, brokers as well as the Danish Central Bank.

\subsubsection{Copenhagen Stock Exchange A/S}

Copenhagen Stock Exchange A/S (CSE) is primarily a bond exchange (by end of 2002, 72 percent of its market capitalization was in bonds) and has operated an electronic trading platform since the late 1980s. It is the center of official trading in a wide spectrum of Danish listed securities - bonds, equities, derivatives and money market instruments. Until 1996, it enjoyed a monopoly on trading, listing, reporting and level three regulation of securities offered to the public in Denmark. In 1996, this monopoly was lifted, and the CSE was converted from a selfgoverning institution into a limited liability company, with members receiving 60 percent of the shares and 20 percent distributed to equity and bond issuers. 
Until recently, it operated as a self-regulatory organization (SRO), setting rules on trading admission, prospectuses, conduct rules, trade reporting and on listing requirements and conducting market surveillance. In 2002, to avoid conflict of interests, the rules on prospectuses, trade reporting, takeovers and disclosure were transferred to the Danish Securities Council and the Danish FSA through an amendment of the Danish Securities Trading Act,. ${ }^{103}$ This is in line with the general trend mentioned in Chapter 2.4 to withdraw public service functions from demutualized infrastructure providers.

The Copenhagen Stock Exchange is the only place in Denmark where listed securities are traded and to which deals are reported.

\subsubsection{Værdipapircentralen A/S (The Danish CSD)}

Værdipapircentralen A/S - the Danish Securities Center - is a central securities depository that registers and settles trades of Danish listed securities. All securities are registered electronically which ensures safe custody, trading, and settlement. The Danish Securities Center is also the registrar and, as such, registers the legal ownership of securities. In 2000, the Danish Securities Center converted from an independent institution into a limited liability for-profit company, initially owned by its users. It sets out clearing rules to be approved by the Securities Council.

\subsection{Main regulation of Danish fixed income markets}

As a basic feature, Danish securities market legislation ${ }^{104}$ does not require securities to be issued, traded, cleared or settled in the domestic financial infrastructure, nor to be denominated in the domestic currency (Danske Kroner - DKK).

A primary objective of Danish fixed income market regulation is the pursuit of financial stability. This is generally speaking translated into control over the financial infrastructure (its regulated markets and the securities clearing and settlement system) and its intermediaries. A second objective is to promote transparency in the market and investor protection. This is linked to a more general objective of ensuring equal treatment and avoiding market failure due to information asymmetries (via rules on correct dissemination of information, insider trading, market manipulation, exchange price discovery mechanisms and conduct of business rules). A

\footnotetext{
${ }^{103}$ For the time being (awaiting the final implementation of the 2003 EC Prospect Directive), these functions have temporarily been delegated back to the CSE.

${ }^{104}$ Danish capital market legislation does not consist of a single set of regulations (e.g., a securities markets code). Rather, regulations applicable to the capital markets are found in a variety of acts and orders. However, among these, the Securities Trading Act stands as the basic regulatory instrument with respect to trading, clearing and registration of securities. The act lays the general provisions concerning requirements for listing of securities on a stock exchange, disclosure obligations, mandatory and voluntary takeover bids and precautions against abuse of insider information and price manipulation. Several important detailed orders have been issued under the Securities Trading Act: The Emission Requirements Order set out the requirements applicable to listing of securities on a stock exchange. The Prospectus Order (listed securities) sets out the requirements that the prospectus must comply with in order to ensure that the information given to investors about the issuing company and the securities is correct, complete and not misleading. The Prospectus Order (unlisted securities) contains similar prospectus requirements with respect to certain public offers of unlisted securities.
} 
third objective of regulation, linked with a general objective of efficiency, is to safeguard and promote competition among providers of financial infrastructure services.

The basis ${ }^{105}$ for regulation of fixed income securities is whether or not a service qualifies as a "securities transaction." Act on Securities Trading $\S 1(2)^{106}$ defines "securities transactions" as (1) public offers of securities, (2) purchase and sale of securities for own or third party's account, (3) procurement of purchase and sale of securities, (4) professional advice with respect to securities, (5) portfolio management, and (6) issue underwriting.

So far, adjustments to the regulation of Danish fixed income markets have been based on either (1) a systematic periodic review and benchmarking of the domestic infrastructure and its regulation, ${ }^{107}$ (2) ad-hoc-regulation in response to various market crises and inefficiencies, or (3) implementation of EC legislation, in particular through the introduction of the single market for financial services.

Below is an introduction to the main regulation of Danish fixed income markets. This regulation may differ depending on who the issuer is (see 5.3.1); the type of market on which his securities are traded (see 5.3.2) and on the intermediaries that facilitate it (see 5.3.3); how information in the market is provided (see 5.3.4) and used (see 5.3.5); and finally, on the way its investors are regulated (see 5.3.6) and protected (see 5.3.7).

\subsubsection{Issuance (and regulation of primary markets)}

\subsubsection{General terms and conditions for admitting bonds to listing}

Sections 2 and 21 of the Danish Securities Trading Act defines, that in principle all fixed income securities can be admitted to listing on a Stock Exchange.

Normally, admitting to listing with CSE requires that the bond issuer shall submit a signed application for admission of bonds to listing on the Copenhagen Stock Exchange. ${ }^{108}$ The application shall contain (1) general information about the bond issuer and may also state the reason for the application for admission to listing, (2) information about the loan and the admission of bonds to listing, (3) a timetable for the stock exchange listing, and (4) a draft prospectus. ${ }^{109}$

However, Danish securities legislation has exempted bonds issued by the Danish Government or by mortgage-credit institutions ${ }^{110}$ from the requirement of drawing up a

\footnotetext{
${ }^{105}$ Unlike the regulation of U.S. markets, there is no requirement for issuers to register fixed income securities that are offered or sold to the public.

106 This provision implements the EU 1993 ISD Directive art. 1(4-5) and section $\mathrm{a}+\mathrm{b}$ of its annex.

${ }^{107}$ In particular the first and second stock exchange reforms as mentioned in Chapter 5.1.1EU

${ }^{108}$ Rule 4 of the Copenhagen Stock Exchange's terms and conditions for admitting bonds to listing.

${ }^{109}$ A bond issuer whose securities are not listed on the Copenhagen Stock Exchange shall also submit reports and accounts for the past two financial years, a copy of the latest registered set of articles of association, and the bond issuer's internal rules

${ }^{110}$ The exception for mortgage credit institutions to draw up a prospect reflects the fact that issuance of mortgage credit bonds are issued as tap issues. Thus, Denmark has taken advantage of Article 29 of the European Union
} 
prospectus. Thus, the majority (both in terms of number and volume) of fixed income securities are exempted from the general requirement for issuers of fixed income instruments to prepare and publish a prospectus. ${ }^{111}$

The specific procedures for issuance and market making are described below as they apply to issuance of government bonds (5.3.1.2) and of mortgage credit bonds (5.3.1.3).

\subsubsection{Issuance of Danish Government fixed income securities}

\section{Government borrowing authority}

Under the Danish Constitution, no loans may be raised by the central ${ }^{112}$ government, unless they have explicit legal authority. The statutory basis for government borrowing is set out in the Act on Authority to raise loans on behalf of the central government of $1993 .{ }^{113}$ In this Act the Danish parliament authorizes the Minister of Finance to raise loans on behalf of the central government for a maximum amount of DKK 950 billion, which is the upper ceiling for the total domestic and foreign debt. In connection with borrowing and ongoing debt management, the Minister of Finance is moreover authorized to enter into swap agreements and other financial transactions.

The Danish Constitution furthermore requires that all government expenditure must be authorized under the annual Finance Act or another appropriation act. Therefore, costs of borrowing, e.g., interest costs and capital losses on issue (the difference between the market and nominal values of the loan) furthermore must be appropriated under the annual Finance Act and is thus subject to "double-approval" by the Danish Parliament.

As part of its authority, the Danish government has legal ability to delegate borrowing authority and debt management policy to a government debt agency. Since 1991, the Danish Central Bank (Danmarks Nationalbank) has undertaken the management of the centralgovernment debt. The Minister of Finance holds the overall and political responsibility for central-government borrowing and debt. This division of work is set out in an agreement between the Ministry of Finance and Danmarks Nationalbank.

\section{Government debt instruments and issuance procedures ${ }^{114}$}

Both domestic and foreign borrowings are based on long-term strategies that match the primary objective with a market for Danish government debt securities: to cover the government's financing requirements at the lowest possible long-term borrowing costs, subject to a prudent degree of risk. The overall strategy for government borrowing is agreed at quarterly

2001 "Codified Listing Directive," that allows member states exempt "debt securities issued in a continuous or repeated manner by credit institutions" from drawing up a prospect (see Chapter 3.6.2.2).

${ }^{111}$ The exemption does not apply to GSEs, who therefore must provide a prospectus as part of the listing procedure.

112 The Danish central government offers re-lending and guarantees the borrowing of a number of companies that are engaged in major public key infrastructure projects (bridge buildings etc.). The same constitutional requirement for an explicit legal authority applies for these commitments.

${ }^{113}$ Act No. 1079 of 22 December 1993

${ }^{114}$ For further information, see "Danish Government Borrowing and Debt 2002," Danmarks Nationalbank. 
meetings between the Ministry of Finance and Danmarks Nationalbank on the basis of written proposals from the latter. The Ministry of Finance authorizes Danmarks Nationalbank to execute the adopted strategy. At the meeting in December, the overall strategy for the following year is determined, including the duration band, on-the-run issues, and the expected distribution of sales on-the-run issues. Furthermore, the strategy includes securities eligible for buy-back, re-lending, and securities lending facilities. At the subsequent quarterly meetings, any adjustments and further specifications of the overall strategy for the following quarter are adopted.

Danmarks Nationalbank regularly publishes ex post and ex ante information on Danish government borrowing and debt.

All Government Bonds and Treasury Notes are issued through CSE (by Danmarks Nationalbank and on behalf of the Government). All licensed traders on the CSE have equal access to purchase government securities directly from Danmarks Nationalbank via the electronic trading system of CSE. There is no requirement for bond trading in Denmark to take place via CSE's electronic trading system. A large portion of trades thus takes place through the telephone market, with subsequent reporting of trades to the CSE. All members of CSE are obliged to report bond trading outside CSE within a short period of time (see Chapter 5.3.4).

Treasury Bills are issued at monthly auctions. All licensed traders on CSE as well as Danmarks Nationalbank's monetary-policy counterparties that meet the requirements set for participation in the CSE electronic auction system, have equal access to bid at the auctions.

To support liquidity, there are market-maker schemes for government securities under the auspices of CSE and the Danish Securities Dealers Association. In these schemes, participants commit to setting current bid and ask prices for a specific volume of the relevant bonds.

Most recently, it has been decided to establish electronic trading in the primary market for Danish government bonds using the electronic trading system MTS (See Chapter 3.4.1 - Box 5 ) as the chosen platform. Today MTS is the predominant system for primary market trading of benchmark European bonds. In this connection, it has also been decided to establish a primarydealer scheme for Danish government securities. These decisions will be implemented later this year.

Government Bonds, Treasury Notes and Treasury Bills are registered at VP (the Danish CSD). When government securities are traded today, the trades are normally cleared and settled in VP. As VP is connected to the two European ICSDs (International central securities depositories), Euroclear and Clearstream, Danish government securities can also be held, cleared and settled with them.

\subsubsection{Issuance of mortgage bonds}

All Danish mortgage bonds are issued by mortgage credit institutions (MCIs). ${ }^{115}$ They are specialized commercial banks regulated separately from other commercial banks by a

\footnotetext{
${ }^{115}$ At present, there are eight mortgage banks in Denmark. All of them operate on a nationwide scale, and some of them also grant loans outside Denmark. Mortgage credit loans may be granted either as bond loans or cash loans.
} 
separate mortgage credit act. ${ }^{116}$ MCIs, like all other Danish commercial banks, are supervised by the Danish Financial Supervisory Authority. The legal provisions particular to the Danish mortgage credit system focus on several areas, which aim at protecting the mortgage bond investors: ${ }^{117}$

MCIs are by law prevented from undertaking any substantial currency, liquidity or interest rate risk ("balance principle").

$>$ MCIs are (like all other EU commercial banks) required to maintain a capital adequacy ratio of at least eight percent of their risk-weighted assets.

MCIs are by law prevented from taking on un-collateralized credit risk via regulation on loan-to-value limits, maturities, valuation and repayment profiles.

$>$ Holders of Danish mortgage bonds hold a preferential claim on assets in case of an MCI bankruptcy.

The mortgage credit system has a strong legal position via the Danish Land Registration and Cadastral System.

The Mortgage Credit Act limits the range of business activities of an MCI to the granting of loans against mortgage on real property (residential and/or commercial property) They do not enjoy a monopoly on this market, as also other financial institutions are free to grant loans secured by mortgages. However, the Act gives MCIs an exclusive right ${ }^{118}$ to fund mortgage loans by issuing mortgage bonds and a monopoly to the name "mortgage bonds."119

As the credit risk for MCIs is minimized by the demand that all loans must be secured by a mortgage on real property, as a consequence, MCIs, to a limited extent, focus only on the financial strength of the potential borrower when granting loans and on the value of the collateral. The lack of borrower screening emphasizes the need for efficient screening of the value of the properties under the mortgages. ${ }^{120}$ This is ensured by rules on valuation and on maximum loan-to-value ratio ${ }^{121}$ that restricts the size of individual loans granted by an MCI. In

Both types have several variations, e.g., fixed-interest loans, adjustable interest loans or index-linked loans. Irrespective of the loan type, the mortgage bank will provide the loan amount by issuing mortgage bonds. Mortgage banks will primarily issue three types of bonds: Annuity bonds, serial bonds and bullet bonds. The bulk of the mortgage bonds is issued as fixed-interest, callable annuity bonds, usually with an initial maturity of 20 or 30 years. Further information is available at the Danish Mortgage Bankers Association.

${ }^{116}$ Mortgage Credit Act, cf. Consolidated Act No. 57 of January 20, 2003. From January 1, 2004, all provisions on lending and bond issuance are moved from the Mortgage Credit Act to a separate Mortgage Credit Bond Act (Act No. 454 of June 10, 2003). MCIs are also subject to the joint financial sector legislation as set out in the Danish Financial Services Act (No. 453 of 10 June 2003) which contains provisions about best practices, customer information, ownership, management, consolidation and financial reporting.

${ }^{117}$ For further information, see Jeppe F. Ladekarl: Safeguarding investment in Danish mortgage bonds, Journal of Financial Regulation and Compliance (March 1998).

${ }_{118}$ Mortgage Credit Act $\S 4$.

${ }^{119}$ Mortgage Credit Act $\S 5$.

${ }^{120}$ If a borrower defaults, the MCI has a right to force a sale of the property, thereby getting the means to cover the value of the mortgage (including expenses, unpaid interest etc.). If the sale of the property does not produce a sufficient amount to cover the mortgage debt in full, the borrower is personally liable for the remaining unpaid debt. The fact that the borrower, in case of default, not only loses the property but also runs the risk of losing other financial assets or future income, limits the probability of a willing default.

${ }^{121}$ Mortgage Credit Act $\S 26$. The maximum lending limit is 80 percent of the value of the property for private residential and residential rental properties. The limit is 70 percent for agricultural property, and 60 percent for 
effect, this is a further limitation of the range of business activities for MCIs, excluding them from granting top-up loans to the lender. Such top-up loans are, however, often offered by a commercial bank in the same financial group as the MCI.

Mortgages have a strong legal position via the Danish Land Registration and Cadastral System which is the central registration system for all land in Denmark. The legal position is ensured by a requirement of registration ${ }^{122}$ of mortgages in this central registration system, the existence of a priority rank, and a fast and efficient foreclosure procedure.

The MCI operates as creditor towards the borrower. Thus, its assets are loans against mortgages and, corresponding to the own capital, investments in debt securities and other investment assets. ${ }^{123}$ On the funding side, the MCI issues bonds and, as such, acts as debtor towards the investor (bondholder). As MCIs are credit institutions, they comply with the EC own funds Directive (see Chapter 3.2). Thus, the capital base of an MCI is safeguarded by the own capital of an MCI that must amount to at least eight percent of its risk-weighted assets. ${ }^{124}$

Danish MCIs are by law prevented from undertaking any substantial currency, liquidity or interest rate risk, a consequence of the so-called "balance principle" in the Mortgage Credit Act. ${ }^{125}$ It regulates the financial risk of the MCI resulting from differences in payments between loans and funding, fluctuations in interest and exchange rates and the use of financial instruments. In general, an MCI is exposed to interest rate risk, if its (interest rate sensible) assets have a different maturity than its (interest rate sensible) liabilities. Normally, a commercial bank that funds itself through (short-term) liabilities, e.g., deposit-taking and grants loans (via bond issuance) with a maturity up to 30 years at a fixed nominal interest, will be exposed to an extreme level of interest rate risk. The "balance principle" is a safeguard against

\footnotetext{
industrial property, office and shop property, and vacation homes. This "haircut" of $20-40$ percentage points of the value of the property at the time of the borrowing provides a safeguard against adverse price movements from the time of borrowing until the time of a forced sale of the property. It also lowers the probability of a borrower willingly defaulting (he has nothing to win, unless the value of the property falls below the value of the mortgage). Explicit rules for the prudent valuation of the property minimizes this risk. The primary valuation rule stipulates that valuation has to be made on a cash basis reflecting the market value of the property. However, the value can not exceed the price "a skilled purchaser with a knowledge of the local market and price conditions would pay for the property" - Mortgage Credit Act $\S 41(2)$.

${ }^{122}$ If a property related to a default mortgage loan is sold by compulsory sale, the claims from lenders with a registered right are separated from the mass and are paid (if possible) in the order of priority, i.e., the first mortgage gets paid in full before any second mortgage. Mortgage loans are normally secured by a first mortgage. This priority rank is stipulated both in the provisions of the deed and are usually also respected in standard terms for other registered documents with rights on the property. As the registration is the constitutive act which completes the mortgage, it also protects the MCI (and its bondholders) against other claims on the property, e.g., as collateral for another loan to the borrower.

${ }^{123}$ Contrary to a U.S. type system where assets are sold out of the issuer's balance sheet by a master trust, the loans remain on the issuer's balance sheet. This is the same principle as with German Pfandbriefe.

${ }^{124}$ It is worth mentioning that further Danish initial (absolute) capital requirements requiring MCIs to have own funds of at least DKK150 million by far exceeds the minimum capital requirements set by the EC own funds directive. This requirement further strengthens the MCIs ability to meet its requirements.

${ }^{125}$ Mortgage Credit Act $\S \S 48-49$ and Executive Order No. 1417 of December 22, 2000 on balance of interest- and currency risk with mortgage bond issuance.
} 
this kind of interest rate risk. ${ }^{126}$ It requires the MCI, when issuing bonds, to assure that every year the total payments received by the MCI from its borrowers are equal to the total of the payments to its bondholders. In practice, this is achieved by the MCI issuing a bond or a portfolio of bonds each time a loan is granted and with precisely the same repayment profile and lifetime as the loan. ${ }^{127}$ This also eliminates liquidity risk with the MCI. Thus, put very simplistically, the risk of the MCI is limited to credit risk, i.e., the risk on its borrower's ability to meet their obligations. ${ }^{128}$

\section{Box 8: Regulation of Danish MCIs: a historical snapshot}

\section{The earliest years}

In 1795, a fire roared in Copenhagen and one fourth of the city was burned to the ground. To rebuild the city vast sums were needed. At that time, the maximum interest rate was fixed by law at four percent, and financing was traditionally granted as personal loans without security. The supply of credit was consequently scarce. The need for security became the most important element for the lenders.

In 1797, a group of wealthy citizens in Copenhagen founded the first Danish MCI. It would provide loans secured by a mortgage on real property and with joint and several liability for the borrowers by issuing negotiable debt securities. A similar system had been introduced in Germany in 1769.

The first Danish mortgage act was passed in 1850, and soon after new MCIs were established. Loans were secured on a first mortgage. Loans could not exceed 60 percent of the value of a property, the value of the bonds could not exceed the value of the mortgages, and the loans had to be amortized. Loans with a 60 year maturity were standard.

In 1895, second-mortgage credit institutions (in Danish: Hypotekforeninger) were introduced. The limit on first-mortgage loans to 60 percent of the value of the property and the mutuality of the existing first-mortgage associations contributed to a very strict lending policy. The secondmortgage credit institutions were allowed to grant loans of up to 75 percent of the value of the property

\footnotetext{
${ }^{126}$ The U.S. home financing market closely resembles the Danish market, with callable mortgage-credit loans playing a decisive role. As a consequence of falling long-term interest rates, applications for mortgage-credit conversions to loans at lower interest rates reached a historically high level in the 3rd quarter of 2002. Since the U.S. mortgage-credit sector is not subject to the same balance principle as Danish mortgage-credit institutes the falling interest rates also had a negative impact on the financial situation of the mortgage-credit institutes (source: Danish Central bank, Danish Monetary Review, 4Q2002)

${ }^{127}$ The MCI may still face interest rate risk when investing its own funds. Actually, an investment regulation (Mortgage Credit Act $\$ 60$ ) even forces an MCI to take on interest risk by requiring the MCI to invest at least 60 percent of its investment portfolio in listed bonds. This interest rate risk is, however, reduced by other provisions (Mortgage Credit Act $\S 64$ and Executive Order No. 1417 of 22 December $2000 \S 13$ ), in effect limiting the maturity of its own funds to a maximum of that of the bonds.

${ }^{128}$ The rating company Moody’s Investor Service noted the following about the balance principle in a Special Comment on Danish mortgage bonds ("Danish mortgage bonds - Highly secure financial instruments," May 2002)

"... These regulations are the most detailed and restrictive Moody's has seen so far and therefore provide significant support for the Danish mortgage system."
} 


\section{After world war II}

In 1958, third-mortgage credit institutions (in Danish: Reallånefonde) were set up on initiative from the Danish government. The new institutions were set up as independent business foundations. The third-mortgage credit institutions were allowed to grant loans of up to 75 percent of the value of the property, but for specific purposes only.

In 1970, the Danish Parliament passed a mortgage credit reform. At that time, Denmark had 24 different MCIs, and lenders had to take out mortgage loans with at least three different MCIs to finance a home. The new Mortgage Credit Act introduced massive changes. The three-tier system was changed to a two-tier system, and all MCIs were allowed to grant both first- and second-mortgage loans. Maximum lending maturity was reduced to 30 years. Lending limits were lowered to 40 percent for first-mortgages (i.e., ordinary loans), and second-mortgages were only granted for specific purposes. The 1970-reform lead to a wave of mergers between Danish MCIs.

\section{0 and onwards}

In 1980, a new series of amendments to the Mortgage Credit Act were passed. The two-tier system was abolished and standard mortgage credit came instead. Cash valuation and cash lending limits were introduced as general principles. In 1982, the limit on lending for owneroccupied housing was raised from 40 percent to 80 percent of the value of the property.

Throughout the 1980s the Mortgage Credit Act was amended (loosened or tightened) several times as part of general economic policy efforts to stabilize the Danish economy.

In 1989, the Mortgage Act was reformed in order for the legislation to meet the obligations of Denmark's membership of the European Union and to adapt to EU directives. More importantly the reform removed the restrictions on establishing new MCIs that had been in force since the 1970-reform. New MCIs were to be public limited companies with a minimum solvency ratio of eight percent.

Since then amendments to the Mortgage Credit Act have liberalized and deregulated different aspects of the original Act.

Source: BRF Kredit (www.brf.dk) and Michael Møller \& Niels Christian Nielsen (1997): "Dansk realkredit gennem 200 aar"

\subsubsection{Regulation of market infrastructure}

Presently, the Copenhagen Stock Exchange (CSE) is the only exchange in Denmark where listed fixed income securities are traded and - as fixed income securities are usually traded OTC - to which deals are reported.

A driver behind the first stock exchange reform in 1988 was an inefficient secondary market, partly due to the lack of a short-term (money) market. Therefore, banks had problems exchanging liquidity with each other. This was particularly a problem for small (non-deposittaking), specialized banks dealing in securities, as they often faced difficulties in financing their trades. Therefore, for an interim period the Central Bank stepped in and developed this market 
by providing bid and offer prices on the money market, and as time progressed, it withdrew from the market. Today, Danish money markets are viable; thus, most banks will be able to raise the necessary liquidity in them for meeting their securities settlement obligations.

Another driver behind the 1988 stock exchange reform was to increase competition in the market. One way of achieving this was to allow remote access to the exchange. This was done against the interests of the domestic brokerage community. A second way was to remove the broker monopoly in trading on the exchange. The monopoly was broken in two steps. First, banks were allowed to own broker companies. Second, banks were allowed direct access to the exchange. ${ }^{129}$ Thus, the division that used to be for regulatory purposes between brokerage and banking activity was abolished. Presently, discussion on access to the exchange (e.g., the issues it raises with regard to the quality of counterparts) concentrates on pros and cons in introducing a central counterparty (CCP) as part of the securities trading.

The last part of the first stock exchange reform was to increase supervision of the exchange and of the brokers. Before then, the stock exchange had been a self-regulatory authority (SRO) without any oversight of its SRO obligations. CSE remained an SRO, but public control and supervision of the exchange by the Danish FSA was increased.

Depending on their business, alternative trading systems for fixed income securities may be regulated either as an exchange or as an investment service company.

With regard to clearing and settlement, the Danish CSD is the registrar of all Danish bonds. ${ }^{130}$ It also facilitates clearing and settlement of securities trading and thus is a central component in the Danish fixed income infrastructure. The Danish CSD does not have a monopoly on any of these services, which are available to any entity able to meet the financial and prudential requirements in the Securities Trading Act as they apply to companies that conduct business as a securities registrar ${ }^{131}$ or as clearing institution ${ }^{132}$ in Denmark.

As all securities in Denmark are dematerialized and registered in the Danish CSD, settlement of securities transactions can take place rather easily. This settlement infrastructure is generally considered to be a key element for the rather liquid Danish securities market.

Furthermore, it provides safe custody and thereby has been able to attract international investors to the market.

\footnotetext{
${ }^{129}$ One reason behind this was to avoid waste of capital (in effect, banks that wanted to do broker activity, had to establish a separate brokerage company). Instead, regulation was introduced on banks to ensure division of customer activities from their own portfolio management.

${ }^{130}$ As mentioned in Chapter 5.1.6, trading in listed Danish fixed income derivatives was moved outside Denmark in 2001.

${ }^{131}$ Act on Securities Trading, Chapter 20

${ }^{132}$ Act on Securities Trading, Chapter 15
} 


\subsubsection{Regulation of intermediaries}

The Danish Securities Trading Act apply to all securities dealers (entities engaged with securities transactions. $)^{133}$ It provides securities dealers with an exclusive right to address the public on a professional basis and to offer services as buyer, seller or intermediary of securities. Thus, the following entities have an exclusive right to secondary market trading of Danish fixed income securities: banks ("credit institutions"), investment companies, mortgage credit institutions (see 5.3.1.3), and the Danish Central Bank. ${ }^{134}$ It sets up rules of good business conduct, ${ }^{135}$ internal organization, ${ }^{136}$ on "know your customer" ${ }^{137}$-relations, on treatment of customer assets, and on management of potential conflict of interests with the customer. ${ }^{138}$

There is no concentration rule in Danish securities legislation; thus, no obligation to execute trades through a regulated marketplace. The Securities Trading Act ${ }^{139}$ requires securities dealers to provide for the fair and expeditious handling of client orders. This also obliges securities dealers to ensure the best possible price and the best terms in general for their customer ("best execution"). This provision is in line with the 2002 ISD Proposal (see Chapter 3.2.4).

The question ${ }^{140}$ of "best execution" is especially relevant in pricing of illiquid securities. ${ }^{141}$ In Denmark, this is relevant for certain mortgage credit bonds due to the very high

${ }^{133}$ Act on Securities Trading $\S 1$ (2) defines "securities transactions" as (1) public offers of securities, (2) purchase and sale of securities for own or third party's account, (3) procurement of purchase and sale of securities, (4) professional advice with respect to securities, (5) portfolio management, and (6) issue underwriting.

${ }^{134}$ Also a special Danish public entity (the Danish Financial Administration Agency) is allowed to do securities transactions.

${ }^{135} \S 5(2)$ : A securities dealer, Danmarks Nationalbank and the Danish Financial Administration Agency shall (1) act honestly and fairly towards its clients and in the best interests of the clients and the integrity of the market, (2) act with due skill, care and diligence, in the best interests of its clients and the integrity of the market, (3) have and employ effectively the resources and procedures that are necessary for the proper performance of its business activities, and (4) try to avoid conflicts of interest and, when they cannot be avoided, ensure that its clients are fairly treated.

${ }^{136} \S 5(1)$ : A securities dealer shall organize and manage his business in such a manner that the undertaking (1) has sound administrative and accounting procedures, (2) has safe control and safeguard arrangements for electronic data processing, (3) has adequate internal control mechanisms, also including rules for personal transactions by its employees, and (4) arranges for records to be kept for five years of transactions executed.

${ }^{137} \S 5(3)$ : A securities dealer shall (1) seek from clients information regarding their financial position, investment experience and objectives as regards the execution of the services requested, (2) disclose in its contracts information relevant to clients, including which compensation scheme or equivalent protection will apply in respect of the transaction envisaged, what cover is offered by whichever scheme applied, or that there are no such scheme and protection, and (3) have guidelines as to when an order shall be executed via the systems of stock exchange and make arrangements to ensure that orders are executed accordingly.

${ }^{138} \S 6(1+2)$ : A securities dealer shall be obliged to (1) make adequate arrangements to secure the clients' ownership right in their securities, (2) take adequate measures to secure the funds of the clients, and (3) organize and structure the business in such a way as to minimize the risk of conflicts of interest among the clients of the securities dealer and between the clients and the securities dealer. Also, a securities dealer shall not enter into commitments with respect to the client's securities without the client's consent.

${ }^{139}$ Securities Trading Act § 3(2) and its Executive Order No. 72 of January 31, 2003 on Good Securities Trading Practices for Trading in Certain Securities. A similar rule applies to OTC investments by an investment fund Investment Funds Act $\S 34$.

${ }^{140}$ As a curiosity, another question in Denmark related to "Best execution" has been on who should be the ultimate regulator of the "best execution" rules: The Consumer Ombudsman (with the aim of strengthening consumer 
number of series issued (see 5.1.1 - Table 10). Since not all of these are liquid; therefore, their secondary markets may suffer. ${ }^{142}$

\section{Investment service companies}

Investment service companies (broker-dealers) offer services related to trade in and provision of securities as well as portfolio management and underwriting of issues, as stipulated in the EU 1993 ISD Directive. They are regulated by the Danish Investment Service Companies $\mathrm{Act}^{143}$

The EU 1993 ISD Directive allowed investment service companies access to all EU markets via a license achieved in one of the EU member states ("The EU Passport"). This introduced tremendous changes in the EU investment service markets, and a negative consequence of this was the emergence of a - partly offshore - market of "side street brokers" in Denmark (small investment service companies selling dubious investment products). The Danish FSA has been very active in enforcement of the ISD Directive, and a large number of the applications it received in mid-1990s for access to operate as an investment firm license in Denmark, were denied after intense scrutiny on grounds of lack of fit-and-proper management or an adequate organization with the applicant. Practically speaking, this enforcement activity has eliminated the "side street brokers" market in Denmark.

\section{Inter-dealer brokers and money market brokers}

Inter-dealer brokers are regulated (via minimum capital requirements, company structure, fit-and-proper management, and adequate internal organization), and supervised (by the Danish FSA) if they perform regular operation of a market where bids and offers for purchase and sale of listed securities between securities dealers (banks, investment companies or mortgage credit institutions) and Danmarks Nationalbank are brought together. If so, on the recommendation of the stock exchange where the security concerned is listed or traded, the Danish Securities Council may permit that securities broking is established and may lay down detailed terms for the activity. ${ }^{144}$

protection) or the Securities Council? They were not able to agree on this question themselves (for a short period of time the Danish Consumer Ombudsman and the Securities Council even issued separate - and inconsistent - sets of guidelines). Finally, the Danish Parliament appointed the Securities Council as the ultimate regulator.

${ }^{141}$ Post-trade transparency via rules on reporting (see 5.3.4) has helped avoiding market fragmentation and a more efficient pricing in Denmark. However, this does not in itself ensure fair secondary market pricing, if liquidity is low or the investor does not have direct access to the trading system - or at least to the prices obtained on it. For this purpose other remedies are necessary. Rules on "best execution" is one such possible remedy (another remedy could be to avoid execution of trades every day, and instead introduce a limited trading pattern, e.g., with weekly auctions).

${ }^{142}$ Executive Order No. 72 of January 31, 2003 § 7: "For securities which are traded infrequently, or where, in a situation covered by section 5 (2) hereof, at the time of the transaction there is no bid or offer respectively in the relevant trading systems, the securities dealer shall settle at a price which, under the circumstances, provides the best possible price and the best terms in general for the customer taking into account, among other things, interest rate and price developments, knowledge of supply and demand in the market, the price of any equivalent securities, and accessible market relevant information on the issuer of the securities, as well as the circumstances in general"

${ }^{143}$ Investment Service Companies Act No. 787 of September 19, 2002

${ }^{144}$ Securities Trading Act $\S 47$. 
Money market brokers are regulated similarly if they perform regular operation of a market where money-market instruments (e.g., short-term fixed income securities) are traded or exchanged between the market participants. They enjoy a joint monopoly with stock exchanges to bring together regularly trading in money market instruments. ${ }^{145}$

\section{Custodian banks}

As a consequence of the European universal banking principle, custodian banks are not regulated differently from other banks. In regard to safe custody, in the early 1980s, Denmark experienced a virtual monopoly for the largest Danish banks on custody transactions (they had a de facto monopoly as local custodians for foreign investors in the market). That de facto monopoly was broken as the Danish CSD developed a link with the Belgian ICSD Euroclear and with the Luxembourg ICSD Cedel (today: Clearstream Luxembourg). That allowed foreign investors to hold their Danish securities in Euroclear or Cedel and allowed them to use their usual custodians, if they so preferred. In essence, the development of links to the two European ICSDs has been an important feature in ensuring competition in the Danish fixed income custodian market.

\subsubsection{Secondary market transparency and reporting requirements}

\section{Issuers on-going reporting requirements}

Danish secondary securities market regulation on on-going reporting requirements is a combination of level 1, 2 and 3 legislations. ${ }^{146}$ The CSE listing rules differentiate between disclosure obligations for equity and for non-equity securities.

An efficient secondary market requires that investors have equal and timely access to all relevant information on a securities issuance. Therefore, issuers whose bonds are admitted to listing on the CSE shall meet the obligations stipulated by the CSE on disclosure requirements. A bond issuer shall ensure all market users simultaneous access to any material information about the issuer that may affect the pricing of its listed bonds, and it is also required to make sure that no unauthorized party gains access to such information before it is published. The issuer is also obliged to lay down internal rules to ensure that the disclosure requirements are met.

This includes periodic information (regular reporting) as well as aperiodic information. The periodic information requires issuer to publish its annual financial statement at the latest six months after the end of the fiscal year. From January 1, 2005, in order to comply with the EU 2003 Prospectus Directive (see Chapter 3.6), annual and half yearly reports should be prepared according to adopted international accounting standards.

\footnotetext{
${ }^{145}$ Securities Trading Act $\S 48+\S 49$

${ }^{146}$ Securities Trading Act $\S 27+29$ (= level 1), Executive Order No. 331 of April 2, 1996 on the conditions for the admission of securities to stock exchange listing (level 2), and CSE Rules governing securities listing on CSE (level $3)$. This regulation exceeds the requirements currently imposed by the EU 2001 "codified directive" on the admission of securities to official stock exchange listing and on the information to be published on those securities (see Chapter 3.6).
} 


\section{Pre-trade transparency ${ }^{147}$}

CSE has published guidelines governing the mechanics of setting prices in its trading systems. These guidelines are considered "good conduct of business." They aim at contributing to improving liquidity while preserving anonymity in bid offers. Thus, they aim at striking the important and difficult balance between the necessary and the excessive reporting of price information.

\section{Post-trade transparency ${ }^{148}$}

One of the problems that was addressed in the Danish 1986 Stock Exchange Reform (see Chapter 5.1.1) was lack of liquidity on the CSE in the early 1980s. This was partly due to the fact that trading was then floor-based, and partly to the fact that the majority of trading in fixed income listed securities was OTC. As there was no reporting to the CSE of such OTC trades, markets were segmented. As a consequence of this lack of transparency, the price formation on these securities with CSE was inefficient, and the CSE was mainly a primary market for government and mortgage bond issuance.

Therefore, to avoid market fragmentation - and thus supporting a secondary market with CSE - floor-based trading was replaced with an electronic platform, and members of CSE were put under an obligation to do post-trade reporting of their OTC trading in securities listed with CSE.

Today, the CSE reporting and information system is integrated with the trading platform. ${ }^{149}$ But as most tradings in Danish listed fixed income securities are still conducted OTC (usually as telephone calls between brokers), subsequent reporting to the CSE is today considered the basic element to avoid market fragmentation and inefficiency in the prize formation, as well as to ensure that CSE is able to provide reliable market data to its participants. Danish secondary market legislation thus obliges members of CSE to report OTC trades in which the member has participated ${ }^{150}$ (normally, the reporting has to take place no later than five minutes after the trade has been made). To further protect these functions, Danish secondary

\footnotetext{
147 Securities Trading Act $\S 19(1)+(2)$ and CSEs Guideline for the publication of real-time trading information and calculation of prices, etc., for the SAXESS trading system

${ }^{148}$ Securities Trading Act $\S 33+\S 34$ and Executive Order No. 414 of May 21, 2001 on the reporting of transactions in securities listed on a stock exchange, and CSEs NOREX Member Rules. Presently, the reporting requirements with CSE are being reviewed and, therefore, may be amended soon.

${ }^{149}$ The CSE fixed income trading platform is a part of NOREX, a strategic Alliance between the Nordic Exchanges, which consists of Iceland Stock Exchange, Copenhagen Stock Exchange, Oslo Børs and Stockholmsbörsen. This means that financial instruments listed in Stockholm, Copenhagen, Oslo and Reykjavik can be traded on a common trading platform (thus introducing a common Nordic fixed securities market). The common securities market is regulated by a common set of trading rules.

${ }^{150}$ Also, a securities dealer shall report to CSE trades in financial instruments admitted to listing on another stock exchange or a similar authorized market place in a member state of the European Union or in countries with which the Community has made an agreement. Such trades shall be reported not later than the trading day following the day of the trade before the reporting system closes. The parties are requested to report such trades not later than 30 minutes before the reporting system closes - Securities Trading Act $\S 33+\S 33$ a, Executive Order No. 414 of May 21, 2001 and CSE Rules regulating non-Members reporting of trades to CSE
} 
securities market legislation also requires that securities dealers, who are non-members of the Stock Exchange, are obliged to report trades in listed securities to the CSE (it may, however, be difficult for CSE and the Securities Council to enforce this requirement). ${ }^{151}$

\subsubsection{Market integrity}

Danish regulation on equity market integrity also applies to fixed income securities. In short, the Danish Securities Trading Act imposes two bans on abuse of inside information: a ban on insider trading as well as a ban on unauthorized disclosure of inside information.

The ban on insider trading means that purchase, sale and recommendation to buy or sell a given security shall not be performed by any person with inside information which could be of importance to the transaction in question. According to Danish regulations, "inside information" means non-public information on issuers of securities, securities or market conditions with respect to such securities, which would be likely to have an effect on the pricing of one or more securities, if such information was made public. Information shall be considered made public when a relevant and general conveyance of such information has been made to the market. Information submitted to a stock exchange shall be considered made public once this stock exchange has disseminated such information.

The ban on unauthorized disclosure of inside information means that any person with inside information shall be prohibited from disclosing such information to any other party unless such disclosure is made within the normal course of the exercise of his employment, profession or duties. In special situations a company may need to grant external parties access to inside information, e.g., in connection with mergers, takeover bids, major acquisitions/divestments, etc. In such situations, the company should prepare an internal list of persons - internal and external - who have been granted access to inside information and at what time. Such lists are necessary to have if the Copenhagen Stock Exchange or the Danish Financial Supervisory Authority should contact the company for further information on persons who have had access to inside information and when such access has been granted.

The Danish Securities Act does not distinguish between primary and secondary insiders.

\subsubsection{Prudential rules on investments}

Danish fixed income market regulation does not create captive investors, but rules on restrictions of investments for institutional investors and for investment funds generally favor investments in fixed income securities.

\section{Institutional investors}

The following restrictions ${ }^{152}$ on investments apply to Danish institutional investors (pension funds and insurance companies): ${ }^{.53}$

\footnotetext{
${ }^{151}$ Securities Trading Act $\S 33+\S 33$ a, Executive Order No. 414 of May 21, 2001 and CSE Rules for NonMembers.
} 
(1) Minimum diversification requirements restrict investments in securities from the same issuer (to reduce risks on ownership concentration) ${ }^{154}$ or from the same asset class $^{155}$ to an upper limit compared to the institutions total investment assets. Unlike banks, institutional investors are not required to have a minimum level of liquid assets (as they are long-term contract providers, their liquidity risk is low).

(2) Investment in foreign securities is restricted via a currency matching rule (pension funds are required to cover at least 80 percent of their liabilities with assets in the same or a matching currency). ${ }^{156}$ There are no direct limits on foreign securities.

\section{Investment funds ${ }^{157}$}

For years, trading in fixed income securities was available for wholesale investors only. The introduction of fund managers as intermediaries changed this system, allowing retail investors access to capital markets. Investment funds were introduced in Danish legislation in 1982 for this purpose.

The Danish Investment Fund $\mathrm{Act}^{158}$ allows investment funds to attract investments from the public. ${ }^{159}$ They do not enjoy a monopoly on this market, as other financial institutions are free as well to attract investments and other savings from the public. The Act allows for a more simple regulatory regime as compared to other financial institutions and gives investment funds a monopoly to the name "investment funds" (in its Danish translation).

In accordance with the investment regulations in the UCITS Directive (see Chapter 3.1.1), Danish investment funds may be organized either as general purpose funds, money market funds, guaranteed funds, funds-of-funds or placement funds ${ }^{160}$ (the only difference between them relates to the regulation of their investments). ${ }^{161}$

\footnotetext{
${ }^{152}$ Prudential regulation on investors normally implies restrictions on their investments. Such rules may on the one hand reduce credit or market risks with their investment portfolio, but may on the other hand also introduce negative market effects, ultimately even as financial de-stabilizators.

${ }^{153}$ In general, insurance companies, closed pension funds ("firmapensionskasser") and open pension funds are subject to the same investment regulations in Denmark.

${ }^{154}$ Danish Financial Business Act $\S 164$ : Investment in listed debt instruments of a single entity is limited to five percent of its total investment assets (except for government bonds - no restrictions, and mortgage credit bonds -40 percent). Self-investments are not permitted.

${ }^{155}$ Danish Financial Business Act $\S 163$ : Investments in "High-risk assets" (domestic and foreign shares and unlisted securities) is limited to 70 percent of its total assets.

${ }^{156}$ Danish Financial Business Act $§ 165$ implements the EU Third Life Insurance Directive (see Chapter 3.1.2).

${ }^{157}$ Also referred to as either Mutual Funds, CIS (Collective Investment Schemes) or UCITS (undertakings for collective investment in transferable securities).

${ }^{158}$ Investment Associations and Special Purpose Associations Consolidated Act No. 658 of August 7, 2002 ("Investment Funds Act"). It also implements the EC 1985 UCITS Directive (see Chapter 3.1.1).

${ }^{159}$ Investment Funds Act $\S 1$ : "This Act shall apply to investment associations 1) the object of which is, from a large number of persons or from the general public, to receive funds which, in accordance with a principle of riskspreading, are placed in securities in accordance with the rules in Part 9 of this Act, and 2) which on the request of a member shall redeem the member's share of the assets with means derived there from."

${ }^{160}$ As mortgage bonds are preferred investment objectives among Danish savers, pure mortgage bonds funds are common. A further investment rule than the ones defined in the UCITS Directive Art. 22(4) limits the numbers of
} 
Today, resident banks or registered branches of foreign banks are the primary custodians/trustees of the funds operating in the Danish market. ${ }^{162}$ The funds may be either selfmanaged or the management may be out-sourced to an external administration company. An external administration company will have to be approved by the Danish FSA in order to conduct the management of the funds. An administration company must be established as a Limited Liability Company and its sole activity must be the management of funds. There are no stated quantitative limits on the fees charged by the administration companies.

\subsubsection{Investor protection}

\section{The Danish Investor Guarantee Scheme}

The Danish Guarantee Fund for Depositors and Investors ${ }^{163}$ covers losses suffered by an investor as a consequence of a bank, mortgage bank or investment company being unable to return securities ${ }^{164}$ owned by the investor which are held in safe-custody or are subject to management or administration by the bank, mortgage bank or investment company. The loss is covered net of loans and other liabilities of the investor up to the equivalent of EUR 20,000 per investor.

As a general rule, securities will not be affected by the suspension of payments or compulsory winding-up of a bank, mortgage bank or investment company since normally an investor will be able to have his securities returned irrespective of the suspension of payments or compulsory winding-up. In some cases, however, securities, which are held in safe-custody or are subject to management or administration by a bank, mortgage bank or investment company that has suspended payments or filed for compulsory winding-up may not be returned to an investor. In such cases the Fund will cover losses due to the non-return of the securities up to the equivalent of EUR 20,000 per investor after deduction of the debt of the investor vis-à-vis the bank, mortgage bank or investment company. However, an investor cannot receive more from the Fund than the value of the securities that are not returned.

Investors are protected irrespective of their own status (wholesale as well as retail investors) or the nature of their investments (listed papers or private placements). However, the Fund does not cover losses resulting from the failure of the issuer of securities to fulfil its

qualified investments (= investments in bonds from a single issuer that exceed five percent of the funds total assets) in a placement fund to a total of 80 percent of its assets - Investment Funds Act § 64(3).

${ }^{161}$ Presently, hedge funds are not allowed to operate under an investment fund-authorization in Denmark. However, this may be changed later this year.

${ }^{162}$ With DKK 324 bill. (= EUR 43,5 bill.) under administration Mid of 2003, the Danish investment fund industry is not large in a European context. This is partly due to widespread direct bond ownership (costs are often lower for retail investors in direct ownership of bonds compared to the administration fees implied with indirect bond holding via an investment fund) and the fact that the Danish tax system benefits institutional pension savings.

${ }^{163}$ The activities of the Fund are governed by the Consolidated Act No. 656 of 7 August 2002 on a Guarantee Fund for Depositors and Investors, and Executive Order No. 216 of 9 April 1999 issued by the Danish Financial Supervisory Authority. These legislative acts implement the EU 1996 Investor Compensation Schemes Directive (see Chapter 3.2) into Danish legislation.

${ }^{164}$ As defined in Section 2 of the Danish Act on Securities Trading, etc. in particular equity securities, debt securities and negotiable mortgage deeds. 
obligations pertaining to the securities (the counterparty risk). Nor will it cover an investor's financial losses due to the depreciation of the investor's securities.

\subsubsection{Taxation}

Taxes in the primary market

Normally, issuance of bonds in Denmark is free of stamp duty. Issues of non-negotiable debt securities may be liable to a stamp duty of one percent.

Taxes in the secondary market

Investors do not pay taxes on the transfer of securities. Individuals or companies liable to Danish tax law may be taxed on capital gains ${ }^{165}$ arising in connection with the transfer of bonds. There is no with-holding tax on debt instruments.

\section{CHAPTER 6: CONCLUSIONS}

Regulation and supervision of fixed income markets is defined at the European level and the national level. European fixed income markets are presently undergoing major changes in size, infrastructure and regulation. Forces for change are due to market factors (e.g., the aging of Europe's population and infrastructure consolidation) as well as to political factors, especially enhanced integration of EU capital markets via the introduction of EMU.

European regulation of fixed income markets is not homogeneous across member countries. At the national level, regulation and infrastructure illustrates national experiences in capital market development. In some countries fixed income market regulation has been developed after intense political reflections on ways and means of promoting safe and efficient capital markets. In other countries, fixed income market regulation is a product of learning-bydoing (e.g., ad hoc reflections based on negative market experiences, financial scandals, etc.).

Thus, in short, European fixed income securities markets are regulated at member state level, and with a European financial market integration project as a common denominator. The study describes the current state of European level regulation as well as two examples of fixed income markets at national level: France as an example of a country from the Euro area, and Denmark as an example of a country outside the Euro area.

Presently, there is no EU-SEC as the institutional framework on fixed income regulation is based on cooperation between national securities regulators.

Box 9 below is a summary of the key elements of European regulatory framework on fixed income securities.

\footnotetext{
${ }^{165}$ Non-residents are normally exempt from Danish taxes
} 


\section{Box 9: Summary of key European regulatory framework}

\section{A. Basic regulatory framework for all securities (fixed income as well as equities)}

A first series of measures relates to the functioning of capital markets, their intermediaries and investors:

The 1993 Investment Services Directive (ISD) covers services related to financial instruments, notably secondary market trading of securities. For example, it addresses reporting of transactions, conduct of business rules, and rules on regulated markets (it is presently being reviewed and is expected to be modernized in 2003 or 2004 following the expected adoption for a new Directive on Investment Services and Regulated Markets)

The 1993 Capital Adequacy Directive (CAD) on the capital adequacy of investment firms and credit institutions addresses the minimum capital requirements necessary to provide investment services in the securities field.

The 1997 Investor compensations schemes Directive addresses the case of an investment firm's inability to repay funds belonging to investors.

The 1985 UCITS modified Directive on the coordination of laws relating to undertakings for collective investment in transferable securities covers investment rules for such entities.

A second series of measures sets minimum disclosure rules for securities issuers and on ensuring market integrity

The 2002 IAS Regulation requires companies with listed securities to comply with international accounting standards

The 2002 Market Abuse Directive on insider dealing and market manipulation deals with antifraud provisions

The 2003 Prospectus Directive harmonizes the requirements for the drawing-up, scrutiny and distribution for the prospectus to be published when securities are offered to the public or admitted to trading on a regulated market, and also covers initial disclosure requirements.

The 2001 "Codified listing" Directive regulates admission of securities to official stock listing, e.g., listing requirements and periodic and ongoing disclosure requirements (it will be partially modernized following the expected adoption of a 2003 Directive on the harmonization of transparency requirements with regard to information about issuers whose securities are admitted to trading on a regulated market)

\section{B. Specific regulatory framework for fixed income securities due to instrument characteristics:}

In some cases, the basic regulatory framework is adapted to the specific nature of fixed income securities and to their markets.

In the 1993 ISD Directive and the new proposal, differentiated rules are applicable notably regarding reporting of transactions, best execution and centralization of orders. 
In 1985 UCITS Directive, fixed income securities benefit of a more favorable treatment for investment rules compared to other securities.

In the 2003 Prospectus Directive, issuers of fixed income securities benefit from adapted schedules of information and possibly specific format of prospectus.

In the 2001 "Codified listing" Directive and the transparency proposal, adapted and less stringent requirements for issuers of fixed income securities compared to equity issuers are enshrined.

In the context of the 2002 IAS Regulation, a specific transitional period is applying for issuers of fixed income securities with no shares listed.

\section{Specific regulatory framework for fixed income securities due to issuer characteristics:}

In other cases, the basic regulatory framework is adapted to the specific nature of issuers of fixed income securities.

The 1985 UCITS Directive allows a better treatment for investments in sovereign securities

Sovereign issuers and municipalities are outside of the scope of the 2003 Prospectus Directive however they may opt in on a case by case basis in order to benefit from the provisions related to cross border offers. They are not covered by the 2002 IAS Regulation as they are not part of the companies definition.

They are also subject to the provisions of the $\mathbf{2 0 0 1}$ "Codified listing" Directive. However, they benefit from an adapted and less stringent regime compared to equity issuers, notably for the transparency obligations.

The 2002 Market Abuse Directive also apply to sovereign issuers. However, they benefit from an exclusion of abuses in the context of monetary policy and management of public debt.

\subsection{Prudential rules on investments}

At the beginning of the 1980 s, the need for Community legislation in the field of collective investment undertakings became obvious for the free circulation of such funds. General provisions on free movement of capital were not sufficient for ensuring a UCITS situated in one member state to be marketed in other member states because of the difference between national legislations. Coordination of prudential rules related to UCITS was a precondition to promote the development of a European capital market. Directive 85/611/EEC on UCITS represents the basic framework necessary for investor protection addressing all basic issues related to the investment funds (authorization, functioning, organization, investment policies, disclosure obligations, and commercialization).

Concerning fixed income securities, demand is expected to increase for short-term paper in the assets of UCITS because of the new prudential rules regarding investments and diversification (cf. Chapter 4). 
All investors with portfolios in fixed income securities are exposed to interest rate risk. For financial investors (banks, pension funds and insurance companies), this exposure is met by European prudential regulation that either requires the investor to hedge its interest rate risk or introduces an upper limit for its interest rate risk. An upper limit may either be defined as an absolute limit or - more commonly - relative to the investors' own funds, either via capital requirements or via ceilings on exposure for different asset categories.

However, when defining ceilings on exposure, it should be borne in mind that they may also have negative effects on financial stability. This could be the case if the bank, pension fund or insurance company is forced to sell assets due to an investment restriction, which thus in effect may act as a further market destabilizer.

\subsection{Investor protection}

EU investors represent a very broad base (e.g., banks, pension fund companies, other contractual savings companies and retail investors). They have different levels of access to information on their investments. The remedies available for dealing with asymmetric access to information are described below in section 6.3 on market integrity.

Investor protection is mainly provided for in the EU Investment Services Directive, adopted in 1993 (1993 ISD). The directive establishes the conditions in which authorized investment firms and banks can provide specified services in other member states on the basis of home country authorization and supervision. Services eligible for a passport under the existing ISD include brokerage, dealing, individual portfolio management, reception and transmission of investor orders, and underwriting/placing activities. In addition, the ISD enshrines the right of direct or remote access of any authorized ISD firm to participate in trading on exchanges/regulated markets in other member states. To support the effective exercise of this right, the ISD defines some characteristics for mutually recognized exchanges and imposes some conditions on the operation of those markets

The 1993 ISD refers to the 1993 Capital Adequacy Directive (CAD), which sets capital ratios for investment firms and for the trading book of banks.

The 1993 ISD mainly regulates EU secondary equity and corporate bond markets and as a general rule - only to a limited extent provides regulation on fixed income securities that differs from that of equities. It focuses on retail investors (protection of small investors, via rules on transparency and disclosure of the price formation process) as well as of wholesale investors (rules on access).

In November 2002 the Commission adopted a suggestion for a Directive that will replace the present 1993 ISD (The 2002 ISD Proposal). The background for the proposal is a general acceptance that the 1993 ISD no longer provides an effective framework for undertaking investment business on a cross-border basis in the European Union. It does not establish clear ground rules within which competition and consolidation of trading infrastructures (exchanges and other trading venues) can take place. 
Investor protection is also provided for in the $1997 \mathrm{EU}$ Investor Compensation Directive requires member states to set up one or more investor compensation schemes. All investment firms supplying investment services must belong to such a scheme. The compensation scheme operates where an investment firm is unable to meet its obligations arising out of investors' claims. The Directive sets a Community minimum level of compensation per investor of ECU 20,000, while at the same time authorising member states to provide for a higher level of compensation if they so wish. However, certain categories of investors may be excluded by member states from the scheme's coverage or may be afforded a lower level of coverage.

\subsection{Market integrity}

As regards transparency and reporting obligations of trades for fixed income securities, the adoption of the Investment Services Directive in 1993 was one major step in the completion of first set of Directives related to securities market. It enshrines the freedom to provide to financial services in the field of investment firms. Integration of European capital was the driving force of this legislative text. The removal of barriers related to the provision of financial services on a passport basis was accompanied by a Community framework of prudential nature notably for investor protection and financial stability reasons.

Transparency and reporting obligations of trades for fixed income securities were among the disclosure obligations necessary for better functioning of secondary markets. However, the level of harmonization in this area is weak for different reasons. First, it is highly related to the disclosure obligations set out by exchange rule books and there are more than 20 exchanges within the European Union plus several bond trading platforms. Second, the market is mainly on an OTC basis and off exchange and there is no real will from market participants to enhance the minimum level of transparency on the trades. There is no differentiated approach in Community legislation for fixed income securities. The transparency requirements on trades are set at the level acceptable by market participants for wholesale markets such as the Eurobond market where anonymity is important. It is difficult to envisage strong improvements in this area for the time being. However, some developments in markets will probably create the conditions for increased transparency on trades for fixed income securities.

The introduction of the Euro has enhanced the competition between member states for the issuance of government bonds. Increasing transparency is a policy tool for member states to differentiate themselves. The second important element is the growing concentration of trading on few fixed income securities trading platforms. Market participants on bond markets seem less reluctant to adopt market models closer to the equity model. Improved liquidity and better prices override the possible costs link to the increase of transparency for operators.

Contributing to investors' confidence is the major objective of the 2003 Market Abuse Directive in line with the first insider dealing Directive adopted in 1989 now repealed. This text has no real impact on the economic development of European capital market and will not bring major improvements in the integration of the EU securities market. However, this Directive constitutes the basic framework for the prevention of wrongdoing practices on securities markets. 
This new Directive should be transposed by member states by the end of September 2004. Because of its repressive nature, this text should not have many implications in the day to day functioning of fixed income securities market in the European Union. Furthermore, criminal and civil laws at national law will not be affected by this Directive, even if some member states will align on a voluntary basis their national legislation in these areas on the basis of this Directive. It is expected that case laws will still have influence on the way administrative sanctions will be pronounced by competent authorities and that there will be important divergence in the level of sanctions.

However, it can be envisaged an increase of investigations related to fixed income securities markets because of the broader scope of securities covered by the text but also because of the broader definition of market abuse compared to the previous limited to insider dealing.

\subsection{Market infrastructure}

The 1993 Investment Service Directive sets the basic conditions for a securities market to be recognized as a regulated market. It has led to strong competition between financial centers as investment firms have made extensive use of their right to become remote members of a regulated market. It regulates secondary markets only, and does not provide a solution to the fact that European primary fixed income markets are not yet fully liberalized. In particular, primary dealer markets do not fall within the scope of the EU Investment Service Directive; thus, there is no european passport (single license) for primary dealers yet.

Trading in fixed income securities in Europe has historically been over-the-counter (OTC). Often, the local stock exchange provides trading systems that also allow for trading in fixed income securities, but often not much trading occurs on these systems. To compensate for this, the regulatory framework of the stock exchange often requires certain intermediaries in the market infrastructure to report information on their OTC trading in fixed income securities to the stock exchange for quotation purposes. This is essentially provided for to establish reference rates for the secondary market and / or for regulatory (tax) purposes.

New ways of trading securities have paved the way for a reform of the 1993 ISD Directive, suggesting that Automatic Trading Systems (in ISD-terms: Multiple Trading Facilities - MTFs) should be regulated as a new category of investment firm, intended to clarify the nature of this business for the purposes of EU law, and to allow for the application of a common set of customized regulatory disciplines to deal with (market-facing) risks. On this basis, MTFs will be able to make their facilities and services available to users throughout the European Union on the basis of home country authorization.

There is no EU prudential framework (authorization, ongoing supervision and mutual recognition) for intermediaries that provide clearing and / or settlement functions for fixed income securities transactions. Thus, regulation of such functions with, e.g, registrars, common depositories, central clearing counterparties (CCPs) central securities depositories (CSDs) and certain custodian banks, is a matter for regulation at the member state level. 


\subsection{Intermediaries}

Historically, corporate financing in Europe has been provided via banks rather than on capital markets. Accordingly, regulation of financial functions in Europe to a large extent is based on regulation of financial intermediaries (e.g., banks and investment service providers) and financial functions (e.g., public offers) rather than financial products (e.g., bonds or equity).

Regulation of intermediaries is based on the principle of universal intermediaries. Thus, European banks are regulated as universal banks (e.g., the concept of SPVs is not introduced in EU banking regulation) and investment service providers as universal brokers (e.g., EU legislation does not yet differentiate between brokers, dealers and broker-dealers).

Investment service providers (brokers) and brokerage services of EU banks are regulated via the 1993 Investment Service Directive (ISD) and the 1993 Capital Adequacy Directive (CAD). ISD defines the modalities for the free provision of investment services in the European Union for investment firms. The ISD refers to the CAD, which sets capital ratios for investment services firms as well as for the trading books of banks. Also banks (credit institutions) are entitled to provide investment services on the basis of a banking license as long as they comply with specified provisions of the ISD (e.g., conduct of business rules).

\subsection{Issuers' obligations}

Before the adoption of IAS regulation, there was no difference in Community legislation between listed and unlisted companies (with some exceptions like consolidation rules). Traditional accounting Directives $\left(4^{\text {th }}\right.$ and $7^{\text {th }}$ Company law Directives) provide the accounting framework coordinating the national GAAP of member states. However, the absence of comparability of financial statements prepared by EU companies, because of the different national options, was a major obstacle for investment in securities of other member states. Integration of EU capital markets through maximum harmonization of accounting standards is the main objective. It should lead also to higher investor protection with adoption of a comprehensive set of financial reporting obligations.

Major improvement is expected with the first application of IAS Regulation with a real impact on integration of EU capital markets. The enhanced comparability of EU companies' financial statements should promote the diversification of investments by investors and reduce the natural bias of investing in national securities. This is true also for fixed income securities where analysts are studying the financial position of the issuer as well as its ability to fulfill its commitments.

Community legislation on prospectuses was primarily adopted for investor protection reason with the introduction of minimum sets of initial disclosure requirements for certain type of securities. This text has a prudential background but also relates to pre-contractual obligations in the context of an offer of securities to the public. At the beginning of the 1980s, there was not yet request for legislative texts that would help to promote pan European offers and multiple listings. However, Community legislation on prospectuses was modified at several occasions to provide for at new disposal aiming at facilitating cross border operations. However, the 
amendments to the original did not provide the expected effects because of the minimum coordination nature of disclosure requirements and the various national options.

With the introduction of the new Prospectus Directive, a significant increase of offers or listing in several member states is expected because of harmonization of the disclosure document at the moment of an offer to public of securities or at the moment of listing securities. This foreseen impact is also valid for fixed income securities notably with a greater development of wholesale markets with an EU coverage compared to national bond markets.

The rationale behind existing Community legislation on disclosure of corporate information on a periodic and on going basis derives from the necessity to ensure investor protection and thus contributes to a better functioning of financial markets. However, coordination of such requirements brings a fuller interpenetration of EU securities markets.

The revision of periodic and on going information obligations should not create new major incentives for the development and the integration of EU capital markets. However, it is also part of the harmonization of the financial reporting framework in order to enhance and modernize the financial information at the disposal of investors. An upgraded minimum level playing field on this matter should favor the already existing trend of convergence on disclosure practices.

\subsection{Taxation}

For the time being, there is no Community text related to securities taxation regime because of limited competence in the Treaty. However, market participants consider this issue as one most important for the free movement of capital within the European Union.

This area will remain a major stumbling block for the coming years for further integration of EU capital markets. The recent adoption of the Directive to ensure effective taxation of savings income in the form of interest payments is an encouraging step, but it will not create the conditions for a real convergence in taxation level. In fact, this text is a compromise between those who favored the absence of a withholding tax and agreed for an exchange of information and those who preferred to maintain bank secrecy and agreed to put in place a withholding tax.

The objective of convergence in taxation level implies major changes in Community arrangements related to taxation. However, this diversity of taxation regimes in member states is not always seen as a barrier. There are also requests for non-harmonized approach in order to maintain competition among member states on this matter. This is particularly true for international segments of fixed income securities markets, notably for Eurobond, where issuers, underwriters, and promoters are seeking best solutions through the choice of listing place. 


\section{REFERENCES}

Andersen, Paul Krüger and Nis Jul Clausen (2003), Børsretten, 2. ed, Jurist- og Økonomforbundets Forlag.

Battley, Nick (1997), The European Bond Markets, 6.ed, The European Bond Commission in association with International Securities Market Association

Danmarks Nationalbank, (2003), Danish Government Borrowing and Debt

De Bondt, Gabe, (2002) "Euro area corporate debt securities market: first empirical evidence», ECB Working Paper No. 164); available at http://www.ecb.int/pub/wp/ecbwp164.pdf

ECB (2001 “The Euro Money Market”, available at http://www.ecb.int/pub/pdf/euromoneymarket.pdf Ferrarini, Guido (editor) (1998), European Securities Markets - The Investment Service Directive and Beyond, Kluwer Law International

Giovannini Group (1997), Report on the impact of the introduction of the euro on capital markets; available at http://europa.eu.int/comm/economy finance/publications/ euro papers/ europapers 03 en.htm

Giovannini Group (1999), The EU repo markets : Opportunities for change; available at http://europa.eu.int/comm/economy finance/publications/euro papers/europapers 35 en.htm

Giovannini Group (2000), Report on coordinated issuance of public debt in the euro area; available at http://europa.eu.int/comm/economy finance/publications/giovannini/giovannini081100en.pdf

Giovannini Group (2001 \& 2003), Report(s) on EU cross-border clearing and settlement arrangements; available at http://europa.eu.int/comm/economy finance/giovannini/clearing_settlement en.htm

Gros, Daniel and Karel Lannoo (2000), The Euro Capital Market, London : John Wiley.

Hansen, Jesper Lau (ed.), (2003) Nordisk Børsret - Reguleringen af kapitalmarkedet i Danmark, Finland, Island, Norge og Sverige, Jurist- og Økonomforbundets Forlag

Hartmann, Philipp, Angela Maddaloni and Simone Manganelli (May 2003), The euro area financial system: structure, integration and policy initiatives (ECB Working Paper No. 230); available at http://www.ecb.int/pub/wp/ecbwp230.pdf,

International Monetary Fund (2001), International Capital Markets 2001; available at http://www.imf.org/external/pubs/ft/icm/2001/01/eng/index.htm

IOSCO (2002a), The Development of Corporate Bond Markets in Emerging Market Countries

IOSCO (2002b), IOSCO Objectives and Principles of Securities Regulation; (updated report with references to work done by IOSCO since September 1998), available at http://www.iosco.org/pubdocs/pdf/IOSCOPD125.pdf

IOSCO (2003), Insider Trading - How Jurisdictions Regulate It 
Ladekarl, Jeppe (1998), Safeguarding investment in Danish mortgage bonds, Journal of Financial Regulation and Compliance, London: Henry Stewart

Lannoo, Karel (1999), Does Europe need an SEC?, European Capital Markets Institute (ERCMI), Occasional Paper No. 1

OECD (2002) Public Debt Markets : Trends and Recent Structural Changes

Report of the Committee of Wise Men on the Regulation of European Securities Markets, published on 15 February 2001, available at http://europa.eu.int/comm/internal_market/en/finances/

general/lamfalussyen.pdf

Santillán, Javier, Marc Bayle and Christian Thygesen (July 2000): "The impact of the euro on money and bond markets", ECB Occasional Paper No. 1; available at http://www.ecb.int/pub/ocp/ecbocp001.pdf,

Schinasi, Garry J. ; Smith, R. Todd ; International Monetary Fund Research Department (1998), Fixed-

Income Markets in the United States, Europe, and Japan-Some Lessons for Emerging Markets

Steinherr, Alfred and Lannoo, Karel (rapporteur) (2001), EU Securities Market Regulation - Adapting to the Needs of a Single Capital Market, CEPS Task Force Report

World Bank and International Monetary Fund (2001), Developing Government Bond Markets - A

Handbook 


\title{
Annex 1: Terms of Reference for the study (in extract)
}

\section{The Regulatory and Supervisory Framework for Fixed Income Markets in Europe}

\author{
For World Bank
}

\section{Background}

The supervisory and regulatory framework for debt markets is inadequate in many emerging countries. There has been a tendency to either project regulation designed for equity markets on to debt markets or leave out regulation all together. Regulation and supervision of debt markets have frequently fallen into a crack between the Securities Commission and the Central Bank. Especially in countries with broad participation and proliferation of debt instruments, a more targeted approach to supervision and regulation of debt markets (its issuers, investors, and intermediaries) might be warranted, both from a financial fragility point of view, as exposure of financial intermediaries to interest rate risk is unchecked, and from an investor protection point of view as direct and indirect retail participation in the market grows.

The World Bank (the Bank) intends to develop policy paper(s) with practical suggestions for how to regulate and supervise debt markets and debt market participants in different circumstances. The focus for the papers and related policy recommendations will be on issues that set debt markets aside from equity markets. The work will form part of the preparatory framework for the financial sector assessments in the area of debt market development.

\section{Deliverables}

The consultant will produce a report providing a detailed account of the regulatory framework for debt markets.

The report should at least but not exclusively focus on:

- Describing the overall regulatory regime for debt markets laid down in the relevant EUdirectives

- Measures taken to ensure investor protection in debt markets (wholesale vs. retail, listed vs. unlisted paper, private vs. public issues)

- Measures taken to ensure debt market integrity (disclosure requirements, insider dealing, market manipulation, corners, etc.)

- Levels of transparency and related reporting requirements. Special regulatory requirements for the valuation of illiquid securities should be given special attention. 
- Regulation of market infrastructure (fixed income trading platforms, interdealer brokers, CSDs, clearing and settlement)

- Regulation of intermediaries in fixed income markets (capital requirements, know you client and order handling rules)

- Regulation and supervision of issuers in the fixed income market (with particular emphasis on differences between government and other issuers)

- Regulation and supervision of investors in fixed income securities (with particular emphasis on CIS with investments in fixed income securities (pricing, accounting standards, disclosure regime))

- The role of different entities, The central Bank, the Financial Market Regulator(s), SROs, Exchanges, and Trading platforms in ensuring compliance with rules and regulations.

Focus should at all times not only be on the legal and regulatory framework for the debt market but also on related supervision and enforcement issues. Differences in approach between regulation of debt markets and debt market participants and regulation of equity markets and equity market participants should be highlighted where appropriate. 


\section{Annex 2 : Size of EU fixed income markets}

The size of the EU fixed income securities markets is not easy to define because of the various existing markets in member states and the importance of the eurobond market (international debt securities market).

The following table indicates the outstanding issues for the 12 member states of the Euro area. It can be broadly estimated that two thirds of this outstanding amount bear fixed-rate coupon and around 20 percent bear a floating rate coupon.

Euro-denominated debt securities by country of residency, sector of the issuer and original maturity

(EUR billion, end-of-period stocks, nominal values)

Amounts outstanding at the end of February 2003

\begin{tabular}{|c|c|c|c|c|c|c|c|c|c|c|c|}
\hline \multirow[t]{2}{*}{ Country } & \multicolumn{3}{|c|}{ All issuers } & \multicolumn{2}{|c|}{$\begin{array}{l}\text { General } \\
\text { Government }\end{array}$} & \multicolumn{2}{|c|}{$\begin{array}{l}\text { Monetary } \\
\text { Financial } \\
\text { institutions }\end{array}$} & \multicolumn{2}{|c|}{$\begin{array}{l}\text { Non- } \\
\text { monetary } \\
\text { financial } \\
\text { corporations }\end{array}$} & \multicolumn{2}{|c|}{$\begin{array}{l}\text { Non-financial } \\
\text { corporations }\end{array}$} \\
\hline & Total & \begin{tabular}{|l|} 
Short \\
term
\end{tabular} & $\begin{array}{l}\text { Long } \\
\text { term }\end{array}$ & \begin{tabular}{|l|} 
Short- \\
term
\end{tabular} & $\begin{array}{l}\text { Long } \\
\text { term }\end{array}$ & \begin{tabular}{|l|} 
Short \\
term
\end{tabular} & $\begin{array}{l}\text { Long } \\
\text { term }\end{array}$ & \begin{tabular}{|l|} 
Short \\
term
\end{tabular} & $\begin{array}{l}\text { Long } \\
\text { term }\end{array}$ & \begin{tabular}{|l|} 
Short \\
term
\end{tabular} & $\begin{array}{l}\text { Long } \\
\text { term }\end{array}$ \\
\hline Euro area & 7598.5 & 773.3 & 6825.2 & 354.4 & $\begin{array}{l}4544.0 \\
\end{array}$ & 317.1 & 2410.7 & 5.9 & 483.1 & 95.8 & 387.5 \\
\hline Austria & 213.6 & 5.1 & 208.5 & 1.3 & \begin{tabular}{|l|l|}
3 & 112.9 \\
\end{tabular} & 3.6 & 88.5 & 0.1 & 2.4 & 0.0 & 4.8 \\
\hline Belgium & 354.6 & 44.2 & 310.4 & 30.2 & \begin{tabular}{|l|r|}
2 & 227.2 \\
\end{tabular} & 5.3 & 64.1 & 3.8 & 0.6 & 4.9 & 18.5 \\
\hline Germany & 2346.7 & 116.0 & 2230.6 & 30.0 & $\begin{array}{l}857.4 \\
\end{array}$ & 58.0 & 1324.0 & 0.0 & 0.0 & 28.1 & 49.2 \\
\hline Spain & 444.2 & 60.1 & 384.1 & 39.1 & 273.5 & 16.7 & 57.6 & 1.1 & 41.0 & 3.2 & 11.9 \\
\hline Finland & 90.2 & 27.4 & 62.8 & 6.2 & 44.5 & 15.8 & 10.0 & 0.0 & 0.0 & 5.3 & 8.4 \\
\hline France & 1551.8 & 320.0 & 1231.8 & 93.3 & 671.5 & 182.8 & 319.3 & 0.0 & 29.8 & 43.9 & 211.2 \\
\hline Greece & 123.5 & 1.5 & 122.0 & 1.2 & 121.6 & 0.3 & 0.1 & 0.0 & 0.0 & 0.0 & 0.2 \\
\hline Ireland & 23.4 & 0.0 & 23.4 & 0.0 & 23.4 & & & & & & \\
\hline Italy & 1606.9 & 127.5 & 1479.4 & 127.4 & 985.5 & 0.2 & 365.5 & 0.0 & 92.2 & 0.0 & 36.2 \\
\hline Luxembourg & 42.4 & 11.0 & 31.4 & 0.2 & 0.4 & 10.8 & 31.0 & & & & \\
\hline $\begin{array}{l}\text { The } \\
\text { Netherlands }\end{array}$ & 695.0 & 47.9 & 647.1 & 23.6 & 168.0 & 22.6 & 123.3 & 0.8 & 315.1 & 0.8 & 40.7 \\
\hline Portugal & 106.3 & 12.6 & 93.7 & 1.9 & 58.2 & 1.0 & 27.3 & 0.2 & 1.8 & 9.6 & 6.3 \\
\hline
\end{tabular}

Source: ECB Securities Issues Statistics.

In 2002, the total issuance of domestic and international bond issuance in Euro Currency (initial maturity above one year) represented 1,469 billions of Euro with 47.7 percent for Central Government, 19 percent for financial institutions, 13.4 percent for mortgage bonds and other covered bonds and 8 percent for corporate (source: European Commission DG Ecfin Quarterly note on the Euro-denominated bond markets No. 47). These figures include both domestic and 
eurobond issues in the Euro area. No breakdown is available but it can be broadly estimated that more than half of the total issuance were made on the international debt securities market.

These figures do not include Euro-denominated debt securities issued by entities situated in United Kingdom, Sweden and Denmark. However, it can be estimated that around three to five percent of the volume of debt securities issued in Euro currency are done by issuers coming from those three member states. The outstanding amount of Euro-denominated debt securities issued by non-euro-zone residents was 1,051 billion of Euro at the end of 2002 of which 985.3 billion for long term securities.

One bias is the issues done by EU issuers in other currencies, notably the national currency of the three member states outside of the Euro area. An even bigger one is the third country issues done on the international debt securities market (either denominated in Euro or in other currencies, mainly U.S. dollars).

The total gross issuance in debt securities in the international debt securities markets represented US\$2,105.4 billion and net issues US\$1,024.1 (source BIS Quarterly Review, March 2003). Euro denominated international debt securities represented US $\$ 811.8$ billion. The market share of Government issues on international debt market (8.2 percent in 2002) is much lower compared to domestic EU fixed income securities markets. Financial institutions are representing 78 percent of the issues and corporate, 10 percent. Fixed rate coupon issues represented 70 percent of the total issuance. 


\section{Annex 3: Illustration of the Lamfalussy-decision procedure}

\section{LEVEL 1}

Commission adopts formal proposal for Directive/Regulation after a full consultation process

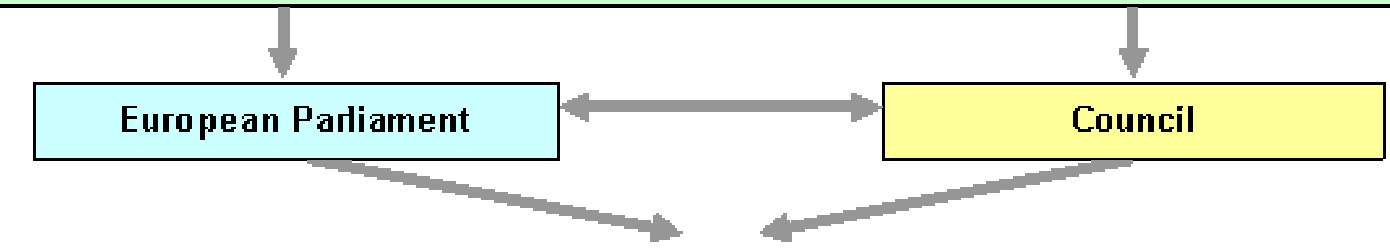

Reach agreement on framework principles and definition of implementing powers in Directive/Regulation

\section{LEVEL 2}

\section{Commission, after consulting the European Securities Committee, requests} advice from the European Securities Regulators Committee on technical implementing measures

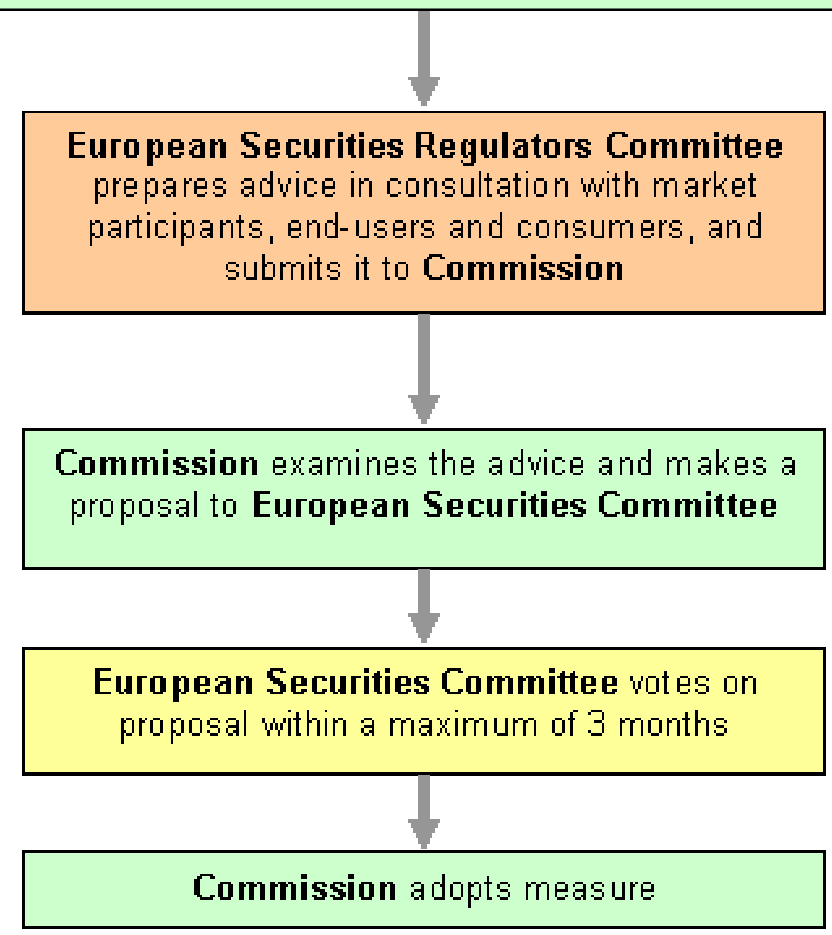

LEVEL 3

European Securities Regulators Committee works on joint interpretation recommendations, consistent guidelines and common standards (in areas not covered by EU legislation), peer review, and compares regulatory

LEVEL 4

Commission checks Member State compliance with EU legislation 


\section{Annex 4: EU regulation of fixed income securities markets}

The basic measure in the domain of investment service is the Investment Service Directive (ISD), which defines the modalities for the free provision of investment services in the EU for brokers and securities markets. The ISD refers to the capital adequacy directive (CAD), which sets capital ratios for investment services firms, and for the trading books of banks. The investor compensation schemes directive introduces a minimum level of protection for retail clients of investment firms.

ISD

ISD Amendment

CAD
Council Directive 93/6 of 10 May 1993 on investment services in the securities field (Official Journal L 141 of 11 June 1993)

Commission Proposal for a Directive on Investment Services and Regulated Markets, and amending Council Directives 85/611/EEC, 93/6/EEC and European Parliament and Council Directive 2000/12/EC of 19 November 2002, COM (2002) 625 final

Council Directive 93/22 of 15 March 1993 on the capital adequacy of investment firms and credit institutions (Official Journal 141 of 11 June 1993), as amended in Directive 98/31 of the Council and the European Parliament of 22 June 1998, OJ 204 of 21 July 1998 (CAD 2)

Investor compensations schemes Directive 97/7/EC of the Council and the European Parliament on investor compensations schemes, OJ L 84 of 26 March 1997

A second series of measures relates to the functioning of capital markets and exchanges, and sets minimum rules regarding particulars to be disclosed for stock exchange listings and initial public offerings, to allow for mutual recognition. Other directives make insider trading and other ways of market manipulation a statutory offence, require firms to disclose major holdings to the market, to use common accounting standards, and a proposal for transparency obligations for publicly traded companies.

\section{IAS Regulation}

Market Abuse Directive
Regulation (EC) No 1606/2002 of the European Parliament and of the Council of 19 July 2002 on the application of international accounting standards, OJ No L 243 of 11.9.2002, page 1

Directive No 2003/6/EC of the European Parliament and of the Council on insider dealing and market manipulation (market abuse), of 3.12.2002, OJ No L 96 of 12.04.2003, page 16 
Prospectus Directive:

"Codified listing Directive"

Transparency Proposal
Council Directive 89/298 coordinating the requirements for the drawing-up, scrutiny and distribution for the prospectus to be published when securities are offered to the public, OJ L 124 of 5.5.1989, page 30 .

Directive 2001/34/EEC of the European Parliament and of the Council on the admission of securities to official stock listing and on information to be published on those securities, OJ L 184, 6.7.2001, page 1.

Commission proposal for a Directive on the harmonization of transparency requirements with regard to information about issuers whose securities are admitted to trading on a regulated market and amending Directive 2001/34/EC (COM/2003/138 final)

Another series of measures allows for the cross-border sale of unit trusts or collective investment undertakings in the European Union. Two proposed amendments extend the scope of unit trusts and harmonize basic rules for the management of unit trusts. Similar regulation has been introduced for certain pension funds.

UCITS

UCITS Amendment 1

UCITS Amendment 2

Pension Funds Directive
Council Directive $85 / 611$ on the coordination of laws relating to undertakings for collective investment in transferable securities, OJ L 375 of 31 December 1985, as amended in Council Directive 88/220, OJ L 100 of 19 April 1988, in European Parliament and Council Directive 95/26/EC of 29 June 1995, in European Parliament and Council Directive 2000/26/EC of 7 November 2000

Council Directive 2001/107/EC of 21 January 2002 (OJ No L 41 of 13 February 2002)

Council Directive 2001/108/EC of 21 January 2002 (OJ No L 41 of 13 February 2002)

Commission proposal for a directive on the activities of institutions for occupational retirement provision (COM/2000/0507 final), (OJ C $096 \mathrm{E}$ of 27 March 2001). Adopted by Parliament in its second reading on 12 May 2003 and by the Council on 13 May.

Finally, some "horizontal" directives and proposals may have an impact on taxation and various aspects of substantial law on securities. This includes protection of settlement procedures, protection of the use of securities as collateral, and finally a proposal for a directive on harmonized procedures for take-overs. 
Taxation of savings

Settlement Finality

Collateral

Take-over Bids Proposal
Council Directive 2003/48/EC on taxation of savings income in the form of interest payments, (OJ L 157, 26 June 2003)

European Parliament and Council Directive 1998/26/EC on settlement finality in payment and securities settlement systems (OJ L 166 of June 11, 1998)

European Parliament and Council Directive 2002/47/EC on financial collateral arrangements (OJ L 168 of 27 June 2002)

Draft $13^{\text {th }}$ company law directive on take-over bids, COM (2002)534 (OJ C 45 E of February 25, 2003) 